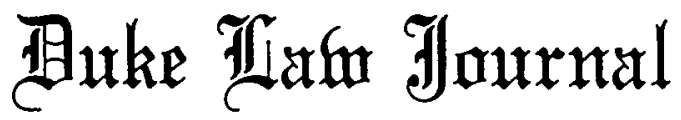

\begin{tabular}{lll}
\hline VOLUME 1984 & FebrUary & NUMBER 1 \\
\hline
\end{tabular}

\section{THE MARKETPLACE OF IDEAS: A LEGITIMIZING MYTH}

\section{STANLEY INGBER*}

Theorists have often heralded the first amendment as creating a neutral marketplace of ideas. Proponents of this model view the market as essential to our society's efforts to discover truth and foster effective popular participation in government. Professor Ingber asserts that the theoretical underpinnings of this model are based on assumptions of rational decisionmaking that are implausible in modern society. He insists that, in reality, the market is severely skewed in favor of an entrenched power structure and ideology. Professor Ingber explores efforts to reform and correct this market defect and finds them equally flawed. He concludes that the marketplace may fulfill its alleged functions only if we explore a theory of freedom of conduct; the market as it exists today simply fine-tunes differences among elites, while diffusing pressure for change by preserving a myth of personal autonomy needed to legitimate a governing system strongly biased toward the status quo.

I. Classic Marketplace Theory $\ldots \ldots \ldots \ldots \ldots \ldots \ldots \ldots .6$

A. A Search for Truth .......................... 6

B. Self-Government and Democracy ................ 8

C. The Impact of Differing Marketplace Perspectives .... 12

D. The Implicit Assumptions of the Marketplace ....... 15

II. Market Reality-Flaw or Status Quo Bias ....... 16

A. The Assumption of Discoverable Truth and An Open Society .................................. 17

1. The Status Quo Orientation of Legal Doctrine .... 17

a. Clear and present danger ................. 17

b. Obscenity $\ldots \ldots \ldots \ldots \ldots \ldots \ldots \ldots \ldots \ldots, 22$

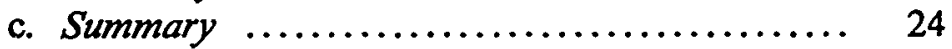

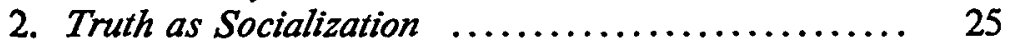

- Professor of Law, University of Florida, Holland Law Center. B.A., 1969, Brooklyn College; J.D., 1972, Yale University. 
B. The Assumption of Rationality $\ldots . . . \ldots \ldots \ldots \ldots . . ., 31$

1. A Problem of Form ........................ 32

2. A Problem of Access and Style ............... 36

a. The mass media .......................... 38

b. The public forum ........................ 40

c. Symbolic conduct ........................ 44

d. Dissidence and unconventionality ........... 46

C. The Marketplace as a Self-Fulfilling Prophecy $\ldots . . .4 \quad 48$

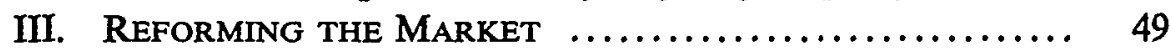

A. Reform Proposals .......................... 50

B. The Dangers of State Intervention $\ldots \ldots \ldots \ldots \ldots \ldots . .65$

1. The Fairness Doctrine ...................... 57

2. Federal Election Campaign Acts $\ldots \ldots \ldots \ldots \ldots . .65$

C. Future Reform Possibilities .................... 69

IV. The Function of the First AMENDMENT $\ldots \ldots \ldots \ldots . .71$

A. Fine-Tuning Among Elites .................... 71

B. Bestowing an Advantage on National Elites ........ 76

C. System Legitimacy and the Myth of Autonomy ...... 77

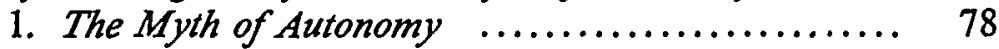

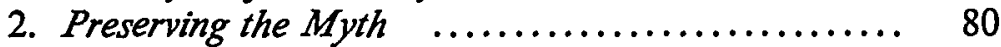

3. Defusing Disenchantment $\ldots \ldots \ldots \ldots \ldots \ldots \ldots . . .64$

V. Conclusion ..................................... 85

Scholars ${ }^{1}$ and jurists ${ }^{2}$ frequently have used the image of a "marketplace of ideas" to explain and justify the first amendinent freedoms

1. See, e.g., T. Emerson, Toward a General Theory of THE First AMENDMENT 7-8 (1966) [hereinafter cited as T. EMERson, First AMENDMENT]; A. Meiklejohn, Free SpeEch AND ITS RELATION TO SELF-GoverNMENT $82-89$ (1948) [hereinafter cited as A. MEIKLEJoHN, Free Speech]; A. MeikLejohn, Political Freedom 73-75 (1960); Baker, Scope of the First Amendment Freedom of Speech, 25 UCLA L. REv. 964, 964-90 (1978); Director, The Partly of the Economic Market Place, 7 J.L. \& EcoN. 1, 3-10 (1964); Ingber, Defamation: A Conflict Between Reason and Decency, 65 VA. L. Rev. 785, $792-94$ (1979); Meiklejohn, The First Amendment Is An Absolute, 1961 Sup. CT. REv. 245, 255-63; Redish, Advocacy of Unlawful Conduct and the First Amendment: In Defense of Clear and Present Danger, 70 CALIF. L. REv. 1159, 1161-62 (1982); Shiffrin, Government Speech, 27 UCLA L. Rev. 565, 583-84 (1980); Wellington, On Freedom of Expression, 88 Yale L.J. 1105, $1129-31$ (1979). See generally T. EMERSON, The SySTEM OF FreEDOM OF EXPRESSION (1970) [hereinafter cited as T. EMERSON, FREEDOM OF EXPRESSION].

2. The marketplace of ideas permeates the Supreme Court's first amendinent jurisprudence. See, e.g., Board of Educ. v. Pico, 457 U.S. 853, 866 (1982); Widmar v. Vincent, 454 U.S. 263, 267 n.5 (1981); Citizens-Against Rent Control v. City of Berkeley, 454 U.S. 290, 295 (1981); Consolidated Edison Co. v. Public Serv. Comm'n, 447 U.S. 530, 537, 538 (1980); FCC v. Pacifica Found., 438 U.S. 726, 745-46 (1978); Virginia State Bd. of Pharmacy v. Virginia Citizens Consumer Council, 425 U.S. 748, 760 (1975); Bigelow v. Virginia, 421 U.S. 809, 826 (1975); Miami Herald Publishing Co. v. Tornillo, 418 U.S. 241, 248 (1974); Red Lion Broadcasting Co. v. FCC, 395 U.S. 367, 390 (1969); Time, Inc. v. Hill, 385 U.S. 374, 382 (1966).

The Court's opinions similarly reflect an image of robust debate. See, e.g., Brown v. Hartlage, 456 U.S. 45, 52-53 (1982); Gertz v. Robert Welch, Inc., 418 U.S. 323, 340 (1974); Miller v. Califor- 
of speech and press. ${ }^{3}$ Although this classic image of competing ideas and robust debate dates back to English philosophers John Milton ${ }^{4}$ and John Stuart Mill, 5 Justice Holmes first introduced the concept into American jurisprudence in his 1919 dissent to Abrams v. United States:" "the best test of truth is the power of thought to get itself accepted in the competition of the market."7 This theory assumes that a process of robust debate, if uninhibited by governmental interference, will lead to the discovery of truth, or at least the best perspectives or solutions for societal problems. A properly functioning marketplace of ideas, in Holmes's perspective, ultimately assures the proper evolution of society, wherever that evolution might lead. ${ }^{8}$

The marketplace doctrine, however, once rooted in American jurisprudence, grew a new shoot that benefitted its new environinent. In addition to its usefulness in the search for truth and knowledge, the marketplace came to be perceived by courts and scholars as essential to effective popular participation in government. ${ }^{9}$ In order for a democ-

ma, 413 U.S. 15, 34 (1973); Rosenbloom v. Metromedia, Inc., 403 U.S. 29, 43 (1971); Red Lion, 395 U.S. at 392 n.18; New York Times Co. v. Sullivan, 376 U.S. 254, 270 (1964).

The Court also has often referred to the marketplace in terms of the competition of ideas that it fosters. See, e.g., Buckley v. Valeo, 424 U.S. 1, 14-15 (1976); Williams v. Rhodes, 393 U.S. 23, 32 (1968); $c$. Virginia State Bd of Pharmacy, 425 U.S. at 762 ("society also may have a strong interest in the free flow of commercial information").

3. The freedoms of speech and press have often been referred to joimtly as the freedom of expression. E.g., T. EMERSON, FREEDOM OF EXPRESSION, supra note 1, at 3.

4. See J. Milton, Areopagitica (London 1644), in 2 Complete Prose Works of John Milton 486 passim (E. Sirluck ed. 1959).

5. See J. Mill, On Liberty, in ON Liberty and Considerations on Representative Government 1, 13-48 (R. McCalluin ed. 1948).

6. 250 U.S. 616 (1919).

7. Id. at 630 (Holmes, J., dissenting).

8. See Corwin, Bowing Out "Clear and Present Danger", 27 Notre DaMe Law. 325, 332-34 (1951). See, for example, Justice Holmes's dissent in Gitlow v. New York, 268 U.S. 652, 673 (1925)("If in the long run, the behiefs expressed in proletarian dictatorship are destined to be accepted . . . the only meaning of free speech is that they should be given their chance and have their way.").

As early as 1644, John Milton similarly argued in an address to the Parliament of England:

[T]hough all the windes of doctrin were let loose to play upon earth, so Truth be in the fleld, we do imjuriously by hicensing and prohibiting to misdoubt her strength. Let her and Falshood grapple; who ever knew Truth put to the wors, in a free and open encounter.

J. Milton, supra note 4, at 561 (footnotes omitted); see Dennis v. United States, 341 U.S. 494, 584-85 (1951)(Douglas, J., dissenting); Abrams, 250 U.S. at 630 (Holmcs, J., dissenting); T. JEFFERSON, First Inaugural Address (Mar. 4, 1801), reprinted in THE COMPLETE JEFFERSON 384, 38485 (S. Padover ed. 1943); see also International Bhd. Elec. Workers, Local 501 v. NLRB, 181 F.2d 34, 40 (2d Cir. 1950); W. BAGEHot, The Melaphysical Basis of Toleration, in 2 LITERARY STUdies 422, 425 (R. Hutton ed. 1879).

9. See, e.g., New York Times Co. v. Sullivan, 376 U.S. 254, $269-72$ (1964); Thornhill v. Alabama, 310 U.S. 88, 102 (1940); Emerson, First Amendment Doctrine and the Burger Court, 68 
racy to function effectively, the citizens whose decisions control its operation must be intelligent and informed. Under this theory, the quality of the public exchange of ideas promoted by the inarketplace advances the quahty of democratic government. Given the importance the United States has placed on democratic government, this view of the marketplace of ideas has helped the freedoms of press and speech to assume something of a preferred position within our constitutional scheine. ${ }^{10}$

This focus on a marketplace seeking truth and proinotimg an informed citizenry has had a curious impact on judicial and scholarly attitudes toward the first amendment. Courts usually articulate constitutional rights as "individual rights" that are justified because of the protection they afford to the person exercising the right. But courts that invoke the inarketplace nodel of the first amendinent justify free expression because of the aggregate benefits to society, and not because an individual speaker receives a particular benefit. ${ }^{11}$ Courts that focus their concern on the audience rather than the speaker ${ }^{12}$ relegate free expression to an instrumental value, a means toward soine other goal, rather than a value unto itself. ${ }^{13}$ Once free expression is viewed solely as an instrumental value, however, it is easier to allow goverument reg-

CALIF. L. Rev. 422, 423 (1980); Karst, Equality as a Central Principle of the First Amendment, 43 U. Chi. L. Rev. 20, 23 (1975).

10. See, e.g., Murdock v. Pennsylvania, 319 U.S. 105, 115 (1943); see also Saia v. New York, 334 U.S. 558, 562 (1947); Marsh v. Alabama, 326 U.S. 501,509 (1945); Thomas v. Collins, 323 U.S. 516, 530 (1945); Follett v. McCormick, 321 U.S. 573, 575 (1943); Prince v. Massachusetts, 321 U.S. 158, 164 (1943); West Virginia State Bd. of Educ. v. Barnette, 319 U.S. 624,639 (1943); Bridges v. California, 314 U.S. 252, $262-63$ (1941); Thornhill v. Alabama, 310 U.S. 88, 95 (1940); Schneider v. State, 308 U.S. 147, 161 (1939); Herndon v. Lowry, 301 U.S. 242, 258 (1937). Chief Justice Stone's dissent in Jones v. Opelika, 316 U.S. 584, 608 (1942), vacated, 319 U.S. 103 (1943), is one of the most frequently cited attempts to recognize first amendment freedoms as being in a "preferred position."

11. Mill stated this quite clearly:

Were an opinion a personal possession of no value except to the owner; if to be obstructed in the enjoyment of it were simply a private imjury, it would make some difference whether the injury was inflicted only on a few persons or on many. But the peculiar evil of silencing the expression of an opinion is, that it is robbing the liuman race; posterity as well as the existing generation; those who dissent from the opinion, still more than those who hold it.

J. Mill, supra note 5, at 14-15.

12. "It is the right of the public to receive suitable access to social, political, esthetic, moral and other ideas and experiences which is crucial here." Red Lion Broadcasting Co. v. FCC, 395 U.S. 367, 390 (1969).

13. Professor Laurence Tribe writes with great veheinence that the freedom of speech must be regarded not merely as a means to some further end, but as an end in itself. L. TRIBE, AMERICan Constitutional LaW \& 12-1, at 576 (1978). Professor Emerson also holds such an "end in itself" perspective. See T. EMERSON, FREEDOM OF EXPRESSION, supra note 1, at 6-8. But see infra note 67. 
ulation of speech if society as a whole "benefits" from a regulated system of expression.

Scholarly critics of the marketplace model argue that the model itself suggests a vital need for government regulation of the market. The imagery of the marketplace of ideas is rooted in laissez-faire economics. ${ }^{14}$ Although laissez-faire economic theory asserts that desirable economic conditions are best promoted by a free market system, today's economists widely admit that government regulation is needed to correct failures in the economic market caused by real world conditions. Similarly, real world conditions also interfere with the effective operation of the marketplace of ideas: sophisticated and expensive communication technology, monopoly control of the media, access limitations suffered by disfavored or impoverished groups, teclimiques of behavior manipulation, irrational responses to propaganda, and the arguable nonexistence of objective truth, all conflict with marketplace ideals. ${ }^{15}$ Consequently, critics of the market model conclude, as have critics of laissez-faire economics, that state intervention is necessary to correct communicative market failures. ${ }^{16}$

This article explores these and other aspects of the marketplace theory of the first aniendment, exposes the theory's fallacies, and explains its persistence. Part I develops classic nuarketplace theory and attempts to expose its basic assumptions. ${ }^{17}$ Part II explores the reality of the marketplace of ideas and asserts that the nrodel's assumptions are implausible. ${ }^{18}$ This section further suggests that the market is

14. Economists have praised the laissez-faire economic model as facilitating optimal production and allocation of goods. See, e.g., M. Friedman \& R. Friedman, Free to Choose 1-13 (1980); A. Marshall, Principles of Economics 63-70 (8th ed. 1950); A. SMith, AN INQUiRY Into THE Nature and Causes of The Wealth of Nations passim (7th ed. London 1793)(1st ed. London 1776); D. RICARDO, Principles of Political Economy and Taxation, in THE WoRKs of DAVID RICARDO I passim (J. McCulloch new ed. 1888); Evans \& Body, Introduction to FrEEDOM AND STABILITY IN THE WORLD ECONOMY 1-2 (D. Evans \& R. Body eds. I976); Furubotn, Worker Alienation and the Structure of the Firm, in Governmental CONTROLS AND THE FREE MARKET 195, 216-17 (S. Pejovich ed. 1976); Simon, The Crucial Issue Is Freedom, in DiLemMas FaCing THE NATION 1 passim (H. Prochnow ed. 1979).

Interestingly, Justice Holmes, whose free speech opinions are the legal origins of this laissezfaire view of the first amendment, see, e.g., Abrams v. United States, 250 U.S. 616, 630 (1919)(Holmes, J., dissenting), also frequently reminded the Court that laissez-faire was not a constitutionally required theory of economic life. See, e.g., Loclmer v. New York, 198 U.S. 45,75 (1905)(Holmes, J., dissenting), overruled, Day-Brite Lighting, Inc. v. Missouri, 342 U.S. 421 (1952).

15. See Baker, supra note 1 , at $965-66$.

16. See, e.g., J. BARron, Freedom of THE Press for Whom? 319-28 (1973).

17. See infra text accoinpanying notes 21-71.

18. See infra text accounpanying notes 72-240; cf. Nagel, How Useful is Judicial Review in Free Speech Cases?, 69 CORNELI L. REv. 302 passim (1984)(arguing that assumptions supporting use of judicial processes to protect free speech implausible). 
strongly biased in favor of positions that support entrenched interests. Part III evaluates proposals offered to overcome this bias and rejects them as unworkable, dangerous, and inconsistent with the articulated purpose of the first amendment. ${ }^{19}$ Part IV considers, in heu of the marketplace of ideas, the more realistic functions of "freedom of expression" in our society;20 it argues that the present marketplace simply fine-tunes differences among elites while defusing pressure for change and fostering a inyth of personal autonomy essential to the continued popular acceptance of a governing system biased toward the status quo.

\section{Classic Marketplace Theory}

\section{A. A Search for Truth.}

Classic marketplace theory assumes that truth is discovered through coinpetition with falsehood and stresses that any authoritatively imposed truth is plagued with the danger of error. ${ }^{21}$ John Stuart Mill thus argued that repression inay interfere with the inarket's ability to seek truth: first, if the censored opimion contains truth, its silencing will lessen the chance of our discovering that truth; secondly, if the conflicting opinions each contain part of the truth, the clash between them is the only inethod of discovering the contribution of each toward the whole of the truth; finally, even if the censored view is wholly false and the upheld opimion wholly true, challenging the accepted opinion must be allowed if people are to hold that accepted view as something other than dogina and prejudice; if they do not, its meaning will be lost or enfeebled.22 Mill accordingly believed that those who considered clashes among coinpeting views unnecessary wrongly presuined the infallibility of their own opinions. ${ }^{23}$

Justice Hohnes also appreciated the danger of assuming infallibil-

ity. He wrote in his Abrams dissent:

Persecution for the expression of opinions seems to me perfectly logical. If you have no doubt of your premises or your power and want a certain result with all your heart you naturally express your wishes in law and sweep away all opposition. To allow opposition by speech seems to indicate that you think the speech impotent, as when a man says that he has squared the circle, or that you do not care whole-

19. See infra text accompanying notes $241-350$.

20. See infra text accompanying notes $351-418$.

21. See J. MiLI, supra note 5, at 13-48; see also J. Milton, supra note 4, at 548-68; J. LOCKE, $A$ Letter Concerning Toleration, in The SeCOND TREATISE of Government (AN EsSAY Concerning the TRUe Original, Extent and END of Civil Government) and A LetTer CONCERNING TOLERATION 125, 139-43 (J. Gough ed. 1966).

22. See J. Mill, supra note 5, at 46-47.

23. Id. at 15 ("All silencing of discussion is an assumption of infallibility."). 
heartedly for the result, or that you doubt either your power or your premises. But when men have realized that time has upset many fighting faiths, they may come to believe even more than they believe the very foundations of their own conduct that the ultimate good desired is better reached by free trade in ideas-that the best test of truth is the power of the thought to get itself accepted in the competition of the market, and that truth is the only ground upon which their wishes safely can be carried out. ${ }^{24}$

Although Holmes wrote these words in dissent, the Supreme Court later embraced the essence of his position when it stated that "[u]nder the First Amendment there is no such thing as a false idea."25

The market model avoids this danger of officially sanctioned truth; ${ }^{26}$ it permits, however, the converse danger of the spread of false doctrine by allowimg expression of potential falsities. ${ }^{27}$ Citizens must be capable of making determinations that are both sophisticated and intricately rational if they are to separate truth from falsehood. ${ }^{28}$ On the whole, current and historical trends have not vindicated the market model's faith in the rationality of the human mind, ${ }^{29}$ yet this faith

24. Abrams, 250 U.S. at 630 (Holmes, J., dissenting).

25. Gertz v. Robert Welch, Inc., 418 U.S. 323, 339-40 (1974); see also id. ("However pernicious an opinion may seem, we depend for its correction not on the conscience of judges and juries but on the competition of other ideas."). For a partial listing of the decisions utilizing the marketplace model, see supra note 2.

26. This is another way of saying that the political state may be an especially unsuitable body to make the determination of what is true and what is false. See American Communications Ass'n v. Douds, 339 U.S. 382, 442-43 (1950)(Jackson, J., concurring in part and dissenting in part); J. Milton, supra note 4, at 559; F. POLLACK, The Theory of Persecution, in EsSAYs in JuRISPRUDENCE AND ETHICs 144, 163-64 (1882); Monro, Liberty of Expression: Its Grounds and Limits, 13 INQUIRY 238, 253 (1970). Free speech issues can be viewed in terms of allocation of institutional competence. In strictly pragmatic terms, the history of official determination of truth has been noted especially for its errors. See Time, Inc. v. Hill, 385 U.S. 374, 406 (1967)(Harlan, J., concurring in part and dissenting in part)("Any nation which counts the Scopes trial as part of its heritage cannot so readily expose ideas to sanctions on a jury finding of falsity."). See generally Fried, Two Concepts of Interests: Some Reflections on the Supreme Court's Balancing Test, 76 HARV. L. REV. 755, 767-70 (1963).

27. Cf. Kalven, A Commemorative Case Note: Scopes v. State, 27 U. CHI. L. Rev. 505, 516 (1960)("classic free speech theory is really a defense of the risk of permitting a false doctrine to circulate").

28. The belief that people ultimately are able to determine truth is, at best, an unverifiable assumption. Mill, for example, assumed that man cannot be certain that he has found the truth. See J. Mill, supra note 5, at 17. Accordingly, the validity of the hypothesis that the public can discover truth through the workings of the marketplace is itself unprovable. More significantly, the same fallibility argument which demands that choices and evaluations be made by inembers of the public individually rather than by government can be made for any governmental action, not just those restricting speech. Recognizing this, Mill responded that "[c]omplete liberty of contradicting and dispproving our opinion is the very condition which justifies us in assuming its truth for purposes of action." Id.

29. Cf. Whitney v. California, 274 U.S. 357, 377 (1927)(Brandeis, J., concurring)("[T]he reinedy to be applied is more speech, not enforced silence. Only an emergency can justify repression."). This unverifiable, idealistic, and perhaps naive view of the power of truth has not gone 
stands as a foundation block for most reeent free speech theory..$^{30}$

\section{B. Self-Government and Democracy.}

Classic marketplace theory recognizes the search for truth as the primary goal of free speech. In the United States, however, constitutional theorists also view free speech as a corollary to democratic theory. For example, Professor Alexander Meiklejohn perceives freedom of speech as an outgrowth of the American consensus that public issues shall be decided by universal suffrage. ${ }^{31}$ The only truth that self-governing individuals can rely upon is that which they themselves devise in the give and take of public discussion and decision. ${ }^{32}$ Meiklejohn argues that

[p]ublic discussion of public issues, together with the spreading of information and opinion bearing on those issues, must have a freedom unabridged by our agents. Though they govern us, we, in a deeper sense, govern them. Over our governing, they have no power. Over their governing we have sovereign power. ${ }^{33}$

uncriticized. See, e.g., M. LeRner, The Mind AND Falth of Justice Holmes 290 (1943); Auerbach, The Communist Control Act of 1954: A Proposed Legal-Political Theory of Free Speech, 23 U. CHI. L. REV. 173, 187 (1956)(citing M. LERNER, supra). The law of defamation, for example, is based on the antithesis of Milton's position that truth always defeats falsehood. See J. MuLton, supra note 8, at 561.

It is unlikely that the dispute over the "power of truth" theory can ever be resolved. The critics of the argument generally speak in the short run-M. LERNER, supra, at 290, uses Nazism as an example of falsity prevailing -and the supporters say only that truth prevails in the long run. Because there is no definition of how long the long run is, however, there is no way either to verify or to disprove the thesis that truth ultimately will prevail.

30. Holmes's marketplace image does not necessarily emphasize the triumph of objective truth through rationality. The inarket can be viewed as a method of approaching truth that is preferable, in spite of its imperfection, to any inethod that relies on governmental determinations of the truth. See Wellington, supra note 1, at 1131. A shightly different view of the marketplace posits that it does not matter whether any objective truth exists. Those views accepted in the marketplace are defined as true; those rejected are by definition false. This has been called the "survival" theory of truth. See Auerbach, supra note 29, at 187 n.25. Viewed in this way, the marketplace is more egalitarian than rational. Individuals have the right to determime truth or falsity not necessarily because they are qualified to do so, but because it "is a deduction from the basic American agreement that public issues shall be decided by universal suffrage." A. MEIKIEJOHN, FreE SPEECH, supra note 1, at 27.

31. A. MeIKLejohn, Free SpeECH, supra note 1, at 27. See generally A. Meiklejohn, Polmical FreEDOM (1960); Meiklejolm, The Barenblatt Opinion, 27 U. CHI. L. Rev. 329 (1960); Meiklejohn, supra note 1 .

32. Meiklejohn insists that in a system of self-government such a process of testing truth through the market "is not merely the 'best' test. There is no other." A. Meiklejohn, Political FREEDOM 73 (1960).

33. Meiklejohn, supra note 1 , at 257 . The first amendment theory adopted by the Supreme Court frequently appears to track Meiklejohn's views. See, e.g., New York Times Co. v. Sullivan, 376 U.S. 254, 273 (1964)(where the ability of the people to act as sovereign was perceived as the "central meaning of the First Amendment"). See generally BeVier, The First Amendment and Political Speech: An Inquiry into the Substance and Limits of Principle, 30 STAN. L. REv. 299, 
In the words of the Supreme Court, "speecll concerning public affairs is more than self-expression; it is the essence of self-governinent."34

The literature on the relationship between free speech and selfgovernment reveals two perspectives. The first, the social value perspective, emphasizes the social value of an informed citizenry. ${ }^{35}$ The second, the mdividual perspective, stresses the importance of a decisionmaking process open to the entire citizenry. ${ }^{36}$ Proponents of the social value perspective imsist that the "best" decisions can only be reached in a democracy if the citizenry is fully aware of the issues involved, the options available, and the interests or values affected. Meiklejohn, a leadimg proponent of the social value perspective, insists that when "a free man is voting it is not enough that truth is known by someone else, by some scholar or administrator or legislator. The voters must have it, all of them."37 Consequently, Meiklejohn argues that no opinion, no doubt, no belief or counterbelief, and no relevant information may be kept from the citizenry. A "profound national commitment" 38 to robust uninhibited debate exists because it is "essential to the welfare of the public."39

If, as Professor Meiklejohn and otllers suggest, deinocratic governance depends on the wisdoin of the voters, all evidence bearing on public decisions must be available to the community without any imtervening "preselection" by the state on the basis of truth or falsity. ${ }^{40}$ Content based restrictions leave the public with an incomplete, and perhaps imaccurate, perception of the social and political universe. Thus, these restrictions can undermine the search for trutl and distort

308-09 (1978); Bork, Neutral Principles and Some First Amendment Problems, 47 IND. L.J. 1, 26-28 (1971); Brennan, The Supreme Court and the Meiklejohn Interpretation of the First Amendment, 79 HARV. L. REV, 1, 14-20 (1965); Kalven, The New York Times Case: A Note on the "Central Meaning of the First Amendment," 1964 SuP. CT. REv. 191, 204-10. Although Justice Brennan did not cite Meiklejohn's works in his New York Times opimion, he has virtually conceded their direct influence. See Brennan, supra, passim.

34. Red Lion Broadcasting Co. v. FCC, 395 U.S. 367, 390 (1969).

35. See, e.g., Karst, supra note 9, at 23.

36. See infra notes $44-53$ and accompanying text.

37. A. Meiklejohn, Political Freedom 75 (1960).

38. New York Times Co. v. Sullivan, 376 U.S. at 270.

39. Associated Press v. United States, 326 U.S. 1, 20 (1945).

40. Thomas Scanlon has ably developed this aspect of free speech theory; he calls it the "Principle of Limited Authority." See Scanlon, Rawls' Theory of Justice, 121 U. PA. L. REv. 1020, 1041-44 (1973); Scanlon, A Theory of Freedom of Expression, 1 PHIL. \& PUB. AFF. 204, 222-26 (1972) [hereinafter cited as Scanlon, Theory of Freedom of Expression]. Scanlon's characterization follows loosely from Kant's notion of individual sovereignty. I. KANT, FOUNDATIONS OF THE METAPHYSICS OF MORALS 50-59 (L. Beck trans. 1959); see also J. LoCKE, supra note 21, at 126-27. Jefferson referred to this as one of the "nnceded portions of right." Letter from Thomas Jefferson to Noah Webster (Dec. 4, 1790), reprinted in 8 THE Wrings of ThOMas JefFerson 111,113 (Memorial ed. 1903). 
the process by which citizens make critical decisions. "lt is [this] mutilation of the thinking process of the community," asserts Meiklejohn, "against which the First Amendment to the Constitution is directed." 41

The social value perspective, however, developed in a culture where the mechanisms of the pamphleteer and the town meeting epitomized free expression. Consequently, all who wished to speak had access to a marketplace where their beliefs could be publicly dissemmated. Right conclusions were "to be gathered out of a multitude of tongues, [rather] than through any kind of authoritative selection."42 Froin this perspective the assumption developed that a free market mechanism for ideas exists in the absence of government intervention. Tlus, proponents of the social value perspective believe that if only government can be kept away from "ideas," the self-operating force of "[f]ull and free discussion" will promote ideas that are "true to our genius" and keep us from "embracing what is cheap and false."43

The second perspective in the literature on the relationship between free speech and self-government stresses the importance of a decisionmaking process open to the entire citizenry. ${ }^{44}$ Proponents of this "individual perspective" assert that each person's ideas have the saine inherent worth ${ }^{45}$ and, thus, each citizen has an equal right to participate in governmental decisionmaking. 46 Therefore, "government must afford all points of view an equal opportunity to be heard."47

41. A. Meikiejohn, Political Freedom 27 (1960)(emphasis omitted). If free speech is to protect "the thinking process of the community" from interference by governmental agents, then there arguably should be no objection when the community determines through the marketplace the "true" or "preferable" position and outlaws froin discussion that which is "false" and "nonpreferable." In this scheme the pubhic, as sovereign, has chosen which of the multitude of tongues spoke the wisest. For further discussion of this point, see infra note 98.

42. United States v. Associated Press, 52 F. Supp. 362, 372 (S.D.N.Y. 1943)(L. Hand, J.), $a f f d, 326$ U.S. 1 (1945). Representative of this perspective is Justice Douglas's eloquent dissent in Dennis v. United States, 341 U.S. 494 (1951):

When ideas compete in the market for acceptance, full and free discussion exposes the false and they gain few adherents. Full and free discussion even of ideas we hate encourages the testing of our own prejudices and preconceptions. Full and free discussion keeps a society fron becoming stagnant and unprepared for the stresses and strains that work to tear all civilizations apart.

Full and free discussion has indeed been the first article of our faith.

Id. at 584 (Douglas, J., dissenting).

43. Dennis, 341 U.S. at 584 (Douglas, J., dissenting).

44. See, e.g., T. EMERson, FreEdoM OF EXPRESSION, supra note 1, at 6-7.

45. This perspective closely parallels the Jacksonian model of deinocracy. See L. LEW1S, Democracy AND THE LAW 199-201 (1963). But see infra text accompanyimg notes 343-53 (discussing whether these ideals serve inerely as a myth to legitinate status quo views).

46. In the United States, all citizens are "peers" and are equally noble. In British culture, a peer is a neinber of a select nobility, distinct from the cominon people. Our Constitution, see U.S. CoNST. art. I, $\$ 9, \mathrm{cl} .8$, and our language have rejected the view that some individuals are of more intrinsic worth than are others.

47. Pohice Dep't v. Mosley, 408 U.S. 92, 96 (1972). 
Proponents of the individual perspective reject the elitist's argu-. ment that only experts are fit to decide specific areas of social pohicy, 48 and accordingly would deny to ehtes control over communications. This egahtarian argument may be based on either concerns of political policy or political principle. ${ }^{49}$ The political policy justification is essentially consequentialist: popular decisions are preferable to elitist decisions because they will lead to more good consequences and fewer bad ones. Meiklejohn is predommantly a consequentialist. Thomas Scanlon, on the other hand, is representative of those who believe that egalitarianism is based on political principle rather than political policy. ${ }^{50}$ Scanlon does not defend freedom of speech because it will lead to better decisions; instead, he contends that government inust recognize the political principle of equal individual worth if it is to legitimately command the allegiance and obedience of its citizens. To be legitimate a government must allow its citizens to recognize governmental authority "while still regarding themselves as equal, autonomous, rational agents." 51

Dean Harry Wellington developed this relationship between personal autonomy and governmental legitimacy inore fully, asserting that "in a secular, democratic society there is no legitimate way in which the mature, legally competent individual can be required to surrender to others responsibility for his moral views." 52 An autonomous person, in Wellington's view, cannot blindly accept the judginent of others. He may rely on the other's judgment, but he must also be able to give independent reasons for believing that opimon to be correct. Thus, a legitimate government, according to both Wellington and Scanlon, must respect this individual autonomy. A legitimate government must recognize the right of each individual to participate in and influence governmental decisionmaking not because decisions reached this way necessarily are best, but because only decisions so derived deserve obedience. ${ }^{53}$ Although Meiklejohn, Scanlon, and Wellington all accept the essential role of the inarketplace of ideas in a democratic process, they

48. See, e.g., B. SkInNer, WaLden Two 54-55 (1948).

49. For a detailed attempt to distinguish between legal decisions based on policy and those based on principle, see Wellington, Common Law Rules and Constitutional Double Standards: Some Notes on Adjudication, 83 YALE L.J. 221 (1973).

50. For a list of some of Scanlon's writings, see supra note 40.

51. Scanlon, Theory of Freedom of Expression, supra note 40, at 214.

52. Wellington, supra note 1, at 1135 .

53. Professor Baker best made this point:

Obligation exists only in relationships of respect .... To justify legal obligation, the community must respect individuals as equal, rational and autonomous moral beings. 
approach their positions from different perspectives: Meiklejohn's concern is that the decisions ultimately made must benefit society; Scanlon and Wellington imsist that the process by which these decisions are reached must be popularly perceived as legitimate. ${ }^{54}$

\section{The Impact of Differing Marketplace Perspectives.}

Constitutional theorists who believe that the only function of free speech is to further self-government can justify restrictions on free speech in a democracy; theorists who believe that free speech furthers a quest for truth cannot justify such restrictions. ${ }^{55}$ If free speech is merely a correlate of democracy then it need extend only to communication pertinent to democratic decisionmaking. A distinction between protected public speech and unprotected private speech might then be justified. A right founded upon the deliberative role of citizens in a democratic political order need not apply to all forms of expression; debates over artistic merit, the best style of personal hfe, or the quahty of Mrs. Smith's pies would probably not qualify for protection. ${ }^{56}$ From this perspective, the concerns of the first amendment only extend to the " "discovery and spread of political truth." "57

Some Supreme Court decisions, ${ }^{58}$ and other scholarly opmions, ${ }^{59}$ seem to accept this bifurcated view of speech; however, the Court has

\footnotetext{
For the community legitimately to expect individuals to respect collective decisions, i.e.,

legal rules, the community must respect the dignity and equal worth of its members. Baker, supra note 1, at 991.

54. But see infra text accompanying notes 351-441 (suggesting that the function of alleged marketplace of ideas is unrelated to respect of individual autonomy).

55. In one sense, theorists who correlate freedom of speech with democracy grant a broader freedoin to expression than do those theorists who focus upon the quest for truth. Proponents of the self-government perspective concede that there may be no truth or that, if it exists, it is unverifable. For these proponents, arguments in the marketplace need only be concerned with prcference, suitability, and practicality, and not with discovery of ultimate truths.

56. Indeed, Professor Meiklejohn viewed the first amendment as an absolute restriction on governmental interference but thought this absolute rule protected only speech pertinent to democratic government. See A. Meiklejohn, Free SpeECH, supra note 1, at 24-25. In later ycars, however, Professor Meiklejohn found the distinction between public and private speech difficult to maintain. He was finally compelled to conclude that "novels and dramas and paintings and poems" also bear upon public issues, and are within the aunbit of the first amendment. Meiklejohn, supra note 1, at 263.

57. Bork, supra note 33, at 31 (quoting Whitney v. California, 274 U.S. 357, 375 (1927)(Brandeis, J., concurring)).

58. See Wolston v. Reader's Digest Ass'n, 443 U.S. 157, 166 n.8, 166-67 (1979)(plaintiff did not thrust himself into public spothight because there was no public controversy, and his refusal to testify before grand jury investigating Soviet espionage did not make him public figure); Hutchinson v. Proxmire, 443 U.S. 111, 134-35 (1979)(first aunendment designed to protect debate on public issues; no public issue because plaintiff only became public figure through the alleged defamation); Young v. American Mini Theaters, Inc., 427 U.S. 50, 61 (1976)(there is "surely a less vital interest in the uninhibited exhibition of material that is on the borderline between pornography and artistic expression than in the free dissemmation of ideas of social and political signifi-
} 
carefully avoided committing itself to such a view. In Abood v. Detroit Board of Education, ${ }^{60}$ the Court recognized:

It is no doubt true that a central purpose of the First Amendment " 'was to protect the free discussion of governmental affairs." " . . . But our cases have never suggested that expression about philosophical, social, artistic, economic, literary, or ethical matters - to take a nonexhaustive list of labels-is not entitled to full First Amendment protection. ${ }^{61}$

Nonetheless, the Supreme Court has made other distinctions based on the self-government justification for free speech in order to find certain statements outside the protection of the first amendment. For instance, although the Court historically regarded the truth or falsity of a behef to be of no legal significance, ${ }^{62}$ it found that the democratic principles justifying the first amendment's protection of opinions does not extend

cance")(Detroit ordinance dispersing "adult" theatres and bookstores upheld); Time, Inc. v. Firestone, 424 U.S. 448, 457 (1976)(requiring actual malice for defamation unjustified where case involving reporting on judicial proceedings "would add almost nothing toward advancing the uninhibited debate on public issues," and where plaintiff neither a public figure nor placed herself in public arena); Gertz v. Robert Welch, Inc., 418 U.S. 323, 342-43, 347 (1974)(standards of first amendinent protection for communications about public figures different than those about private figures); Rosenbloom v. Metromedia, Inc., 403 U.S. 29, 40-44 (1971)("the determinant whether the First Amendment applies to state libel actions is whether the utterance mvolved concerns an issue of public or general concern"); Cohen v. California, 403 U.S. 15, 24 (1971)("free expression . . . is designed and intended to remove governmental restraints from the arena of public discussion"); Rosenblatt v. Baer, 383 U.S. 75, 85 (1966)("[c]riticism of government is at the very center of constitutionally protected area of free discussion"); New York Times Co. v. Sullivan, 376 U.S. 254, 269 (1964)("freedonı of expression upon public questions is secured by the First Amendnient," and it "was fashioned to assure unfettered interchange of ideas for the bringing about of political and social changes" ")(quoting Roth v. United States, 354 U.S. 476, 484 (1957)).

59. See generally BeVier, supra note 33, at 308-09; Bork, supra note 33, at 26-28; Kalven, supra note 33 , at 204-10.

60. 431 U.S. 209 (1977).

61. Id. at 231 (quoting concurring opinion of Powell, J., 431 U.S. at 259)(footnote omitted). Even "prurient, patently offensive depiction or description of sexual conduct" has been held deserving of first annendınent protection if shown to "have serious literary, artistic, political, or scientific value." Miller v. California, 413 U.S. 15, 26 (1973).

62. See Gertz v. Robert Welch, lnc., 418 U.S. 323, 339 (1974)("Under the First Amendment there is no such thing as a false idea."); NAACP v. Button, 371 U.S. 415, 445 (1963); United States v. Ballard, 322 U.S. 78, 86 (1944); id. at 92-95 (Jackson, J., dissenting); see also Kingsley Int'l Pictures Corp. v. Regents, 360 U.S. 684, 688-89 (1959); West Virginia State Bd. of Educ. v. Barnette, 319 U.S. 624, 634 (1943); Cantwell v. Colmecticut, 310 U.S. 296, 310 (1940); cf. International Bhd. of Elec. Workers, Local 501 v. NLRB, 181 F.2d 34, 40 (2d Cir. 1950)(L. Hand, C.J.)(opinion of United States Court of Appeals for the Second Circuit), affd, 341 U.S. 694 (1951).

The Court's policy against imquiring into the truth of a belief at issue under the first aniendinent refiects the Court's dislike for content regulation. See Hudgens v. NLRB, 424 U.S. 507, 52021 (1976); Erznoznik v. City of Jacksonville, 422 U.S. 205, 209-12 (1975); Pohice Dep't v. Mosley, 408 U.S. 92, 95 (1972). See generally Ely, Flag Desecration: A Case Study in the Roles of Categorization and Balancing in First Amendment Analysis, 88 HARv. L. Rev. 1482 (1975); Karst, supra note 9 , at 26-35, 65-67. 
to statements of fact. ${ }^{63}$ Despite Mill's exhortation as to the value of falsehood, 64 the Court has concluded that all ideas, but only accurate statements of fact, further self-government. 65 Under this view, false statements of fact have no constitutional value. The Court accordingly has protected those who spread false information only when it beheved the truth would too often be suppressed by chilling the speech of those unsure of their information's accuracy. ${ }^{66}$ In short, if the first amendinent is viewed as based upon the value of free speech to the democratic process, then the ambit of protected speech encompasses only communications that the courts determine relevant to this concern. ${ }^{67}$

63. See Gertz v. Robert Welch, Inc., 418 U.S. 323, 340 (1974). Philosophers have long debated whether fact can be distinguished from opinion. See, e.g., F. CoOper, LiviNg THE LAW 6 (1958)(observing that facts announced in court opinions are not objectively determined, but are rather the result of subjective judgment and inference); W. BISHIN \& C. STONE, LAW, LANGUAGE, AND Ethics 151, 151-52 (1972)(reprinting S. LANGer, PhILOSOPHY IN A New Key 89-91 (3d ed. 1957)(describing human tendency to abstract forms from sensory experiences as viewed in the light of the past)); W. BiShIN \& C. STONE, supra, at 146-48 (reprinting B. Russell, The PROBLEMS OF PHILOSOPHY 7-12 (1959)(enumerating the difficulties encountered in differentiating between appearance and reality)). The courts, however, seem to beheve that fact can be distinguished from opinion on solnething of an "I know it when I see it" basis.

64. See supra text accompanying notes 21-22.

65. See Gertz v. Robert Welch, Inc., 418 U.S. 323, 340-41 (1974); see also Ocala Star-Bauner Co. v. Damron, 401 U.S. 295, 301 (1971)(White, J., concurring); Time, Inc. v. Hill, 385 U.S. 374, 405 n.2 (1967)(Harlan, J., concurring in part and dissenting in part). See generally Ninuner, The Right to Speak from Tines to Time: First Amendment Theory Applied to Libel and Misapplied to Privacy, 56 CALIF. L. Rev. 935, 949-52 (1968).

66. See Ocala Star-Banner Co. v. Damron, 401 U.S. 295, 301 (1971).

67. Commentators have offered explanations not bascd on a marketplace theory to justify the preferential treatment free expression has received from both the courts and scholars. Professor Einerson, for example, has argued that the first amendinent embodies Western aspirations for individual self-fulfillment and full intellectual development. See T. EMRRSON, FIRST AMENDMENT, supra note 1, at 4-7. His theory proposes that an individual can develop ideas and affirm his conceptions of his "self" only if he can speak freely. Id. at 6-7. It echoes Justice Brandeis's statement that the "final end of the State [is] to unake men frec to develop their faculties." Whitney v. California, 274 U.S. 357, 375 (1927)(Brandeis, J., concurring).

This does not, however, distinguish speech from any other human activity. "An individual may develop his faculties . . . by trading on the stock market, following his profession as a river port pilot, working as a barmaid, engaging in sexual activity, playing tennis, rigging prices or in any of thousands of other endeavors." Bork, supra note 33, at 25; see Schauer, Speech and "Speech"-Obseenity and "Obscenity": An Exercise in the Interpretation of Constitutional Language, 67 GEO. L.J. 899, $911-12$ (1979). He may commumicate his self-view as much by the kind of car he drives-a Pinto or a Mercedes—or the clothes he wears-jeans or three-piece suits-as he does by communication through language. Consequently, Emerson cannot tenably distinguish thought and commnnication from action by claiming that the fonner, but not the latter, is "the fountainhead of all expression of the individual personahty." T. EMERSON, FREEDOM OF EXPRESSION, supra note 1, at 9 . Indeed, behavior may communicate an individual's personality more fully and accurately than any verbal communication-i.e., "a picture is worth a thousand words." Expression, however, nnust not be defined so broadly as to include all behavior. The argument supporting special protection for expression snnply is unconvincing unless the rationale of the first amendinent can be legitimately narrowed so as not to imclude and justify an unlimited freedoin of behavior. The marketplace theory provides prccisely such a narrowing rationale. The self-fulfill- 


\section{The Implicit Assumptions of the Marketplace.}

As the previous sections demonstrate, the economic metaphor of the marketplace emphasizes the uniqueness of each market participant. Furthermore, before there can be any assurance that the ultimate good will triumph in the marketplace, it is apparent that these individuals must fairly and equally consider all ideas through a process of rational evaluation. The existence of this process is based on several implicit assumptions. ${ }^{68}$

First, if truth is to defeat falsity through robust debate in the marketplace, truth must be discoverable and susceptible of substantiation. If truth is not ascertainable or cannot be substantiated, the victory of truth in the marketplace is but an unprovable axiom. ${ }^{69}$ In order to be discoverable, however, truth must be an objective rather than a subjective, chosen concept.70 Consequently, socioeconomic status, experience, psychological propensities, and societal roles should not influence an individual's concept of truth. If such factors do influence a listener's perception of truth, the inevitable differences in these perspectives caused by the vastly differmg experiences among individuals make resolution of disagreement through simple discussion highly unlikely. And if the possibility of rational discourse and discovery is negated by these entrenched and irreconcilable perceptions of truth, the dominant "truth" discovered by the marketplace can result only from the triuniph of power, rather than the triumph of reason. ${ }^{71}$

The second necessary assumption of the marketplace model's emphasis on the power of rationality is that individuals can separate the form in which competing positions are presented from their substance. Individuals must not be influenced by an idea's packaging, no matter how pleasing or offensive it may be to their individual taste; otherwise, the marketplace would favor the most attractively packaged ideas rather than those with the "best" substance.

ment function of the first amendment, therefore, is only a beneficial by-product of market theory and is not an independent justification for the amendment.

68. These assuinptions have been recognized and critiqued by other scholars. See, e.g, F. SCHAUER, Free SPEeCH: A PHILOSOPHICAL ENQUIRY 15-34 (1982); Baker, supra note 1, at 97476; Kendall, The "Open Society" and Its Fallacies, 54 AM. PoL. ScI. Rev. 972, $977-79$ (1960); Richards, Free Speech and Obscenity Law: Toward a Moral Theory of the First Amendment, 123 U. PA. L. REv. 45, 81-82 (1974).

69. In such a case, continued reliance on the marketplace of ideas can be justified only if the market somehow produces the best, if not the true, result, or if the market employs, at least, a preferred method for choosing among potential results. See Baker, supra note 1, at 967.

70. Cf. James, Pragmatism-A New Name for Some Old Ways of Thinking, in READINGS IN JURISPRUDENCE 227, 228 (J. Hall ed. 1938)("Truth happens to an idea. It becomes true, is made true by events.")(einphasis in original).

71. For further consideration of this prospect, see infra text accompanying notes 127-31. 
For the marketplace to accomplish the goals attributed to it, both of these assumptions must hold. Part II, however, demonstrates that experience in the real marketplace fails to confirm these optimistic assumptions.

\section{Market Reality-Flaw or Status Quo Bias}

A free economic market, arguably, values goods and services and allocates resources in a manner that maximizes utility. ${ }^{72}$ if the competitive nature of the market is eliminated, lowever, or if the market's rationality is corrupted through socialization or propaganda, then the marketplace can no longer be trusted to properly value a particular good or service. In fact, just such real world conditions often have prevented "free" competitive economic inarkets from optimally allocating and producing goods and services. The recognized ability of private economic power to skew and manipulate the economic market ${ }^{73}$ has led to popular acceptance of active government involvement in this market. ${ }^{74}$

Although laissez-faire economic theory has diminished in stature, it is curious that those who applaud its demise seem committed to retaming the symbols of a laissez-faire communicative market. ${ }^{75}$ Yet, the

72. See, e.g., K. George \& J. Shorey, The Allocation of Resources 31 (1978); F. Knight, The Economic Organization 32-35 (1951); P. Samuelson, Economics 38-42 (11th ed. 1980); H. Simons, EConomic Policy for A Free Society 46-47 (1948).

73. Many first amendment critics insist that the market of ideas has also been skewed and manipulated:

With the development of private restraints on free expression, the idea of a free marketplace where ideas can compete on their merits has become just as unreahistic in the twentieth century as the economic theory of perfect competition. The world in which an essentially rationalist philosophy of the first aniendment was born has vanished and what was rationalism is now romance.

Barron, Access to the Press-A New First Amendment Right, 80 HARv. L. Rev. 1641, 1678 (1967).

74. Antitrust limitations, mininum wages, maximun hours, truth-in-lending, prohibition of misleading or fraudulent advertising and unconscionablc consumer contracts, and support of farm product prices are intrusions on a laissez-faire system. Yet even the most conservative of our citizens have apparently accepted, in principle, these intrusions. Debate on these issues has instead focused on the extent, degree, and scope of these governmental intrusions into the economic market.

75. See, e.g., Emerson, The Affirmative Side of the First Amendment, 15 GA. L. REv. 795, 796 (1981). One explanation why the philosophy of Adam Smith has been rejected while the beliefs of John Stuart Mill have been praised, if not implemented, is that the two philosophies are directed toward different social classes. Laissez-faire economics assumes that the individual is in the best position to determine his or her own needs and to make decisions accordingly. Government intrusion into the economic market assumes that certam individuals are incapable of ascertaining or effectuating their own good. The breakdown in laissez-faire economics has therefore led to legislation "protecting" blue-collar workers and those with limited education. See examples noted supra note 74. Legal paternalism in the market of speech and ideas, on the other hand, might mipose upon the process of deliberation of those who most identify themselves with such a process: white-collar and educated classes. 
marketplace of ideas is as flawed as the economic market. Due to developed legal doctrine and the inevitable effects of socialization processes, mass communication technology, and unequal allocations of resources, ideas that support an entrenched power structure or ideology are inost likely to gain acceptance within our current market. Conversely, those ideas that threaten such structures or ideologies are largely ignored in the marketplace. The following review of how legal doctrine and marketplace realities affect each of the assumptions of the market model illustrates this status quo bias.

\section{A. The Assumption of Discoverable Truth and An Open Society.}

1. The Status Quo Orientation of Legal Doctrine. A brief review of two promment first amendment doctrines illustrates both their dependence on the marketplace imagery of an open society searching for truth and their contrastimg tendency to support the behefs of the status quo.

a. Clear and present danger. The clear and present danger test ${ }^{76}$ is firmly rooted in marketplace doctrine that "freedom to think as you will and to speak as you think are means indispensable to the discovery and spread of pohitical truth."77 Under this test, government camiot regulate speech solely on the grounds of the intrinsic danger of the ideas being conveyed. Government justifiably can suppress, limit, or forbid speech only when it is dehivered in circumstances that prevent the audience involved from reasonably considering the message before it. In such an emergency setting the marketplace is likely to malfunction because opposing speakers cannot fairly and adequately present their ideas and the public cannot give them a fair and imtelligent hearing. As Justice Brandeis indicated, the danger must be "clear" to prevent suppression based on irrational fear, ${ }^{78}$ and it inust be "present" for

Classic hberals, such as Mill and Bentham, were well-bred gentlemen of the upper crust. They atteinpted to maximize human happiness by minimizing external interference with individual choice. Perhaps such biberals saw mdividual hiberty as the best arbiter of happiness because they were at the apex of British society and needed nothing to make thein happy other than removal of the governmental and moral strictures they found inconvenient. That lawyers would similarly be more solicitous of views opposing paternalism in expression than in economics should not be surprising once it is remembered that they are purveyors of ideas and stand as ehtes in our culture's public decisionmaking processes. See generally Ingber, The Interface of Myth and Practice in Law, 34 VAND. L. REv. 309, 310, 325-31 (1981)(discussing role of lawyer as decisionmaker).

76. Speech is not constitutionally protected when, in Justice Holmes's words, it creates a "clear and present danger that [the speech] will bring about the substantive evils that Congress has a right to prevent." Schenck v. United States, 249 U.S. 47, 52 (1919).

77. Whitney v. California, 274 U.S. 357, 375 (1927)(Brandeis, J., concurring).

78. Id. at 376 . 
"if there be time to expose through discussion the falsehood and fallacies ... the remedy to be applied is more speech, not enforced silence." 79

The clear and present danger test presupposes that market imperfections sometimes give speakers an unacceptable level of advantage in influencing others. Because information opposing the speaker's viewpoint cannot be transmitted instantaneously to all market participants, the real market substantially departs from the theoretical one. ${ }^{80}$ Therefore, emergency situations are exempted from first amendment coverage. As long as sufficient time remains for the marketplace's process of deliberation to persist, however, and as long as lawless action is not imminent, no emergency exists and all speech must be protected.

Yet the goal of free speech is not merely to have citizens enjoy participating in an effete truth-seeking process. Instead, citizens seek truth through free speech precisely to influence choice and behavior. Recognizing that beliefs are important primarily because those who hold them are likely to act accordingly, Holmes conceded that "every idea is an mcitement." 81 Ironically, however, Holmes's "clear and present danger" formula allows government officials to prohibit expression precisely when such speech threatens to incite action. ${ }^{82}$ An interpretation of the first amendment that permits the state to cut off expression as soon as it comes close to being effective essentially limits the amendment's protection to encompass only abstract or innocuous communication. ${ }^{83}$ Consequently, speech is constitutionally protected under the clear and present danger test as long as it is either ineffective $^{84}$ or insignificant. ${ }^{85}$ In either instance the test creates an establishment bias.

79. Id. at 377 .

80. See generally A. Ledonhufvud, Keynes and the Classics (1969).

81. Gitlow v. New York, 268 U.S. 652, 673 (1925)(Holmes, J., dissenting)(An idea "offers itself for belief and if believed it is acted on unless soine other belief outweighs it or some failure of energy stifles the movement at its birth.").

82. Holmes's description in Abrams of the materials that would be protected by his test is apt-the "silly pamphlet [published] by an unknown man," 250 U.S. at 628, and the "poor and puny anonymities" too insignificant "to turn the color of legal litmus paper," id. at 629.

83. Meiklejolm observed the danger that the Holmes/Brandeis test might guarantee freedom only "to engage in mere academic and harmless discussion." A. MEikLEJoHN, FreE SPEECH, supra note 1 , at 44.

84. For example, a speech counselling against participating in the military draft made before an unsympathetic chapter of the Veterans of Foreign Wars would not be perceived by courts as posing a clear and present danger, although the same speech given before a group of college students of draftable age might well be so viewed. If the speech before the students can be proliibited or criminalized, expression would be cut off precisely at the point when it was likely to be most meaningful. For decisions suggesting that the clear and present danger test might not even allow discussion in the first, less threatening, context above, see, for example, Debs v. United States, 249 U.S. 211, 216-17 (1919); Froliwerk v. United States, 249 U.S. 204, 210 (1919), where 
Other factors peculiar to the clear and present danger test accentuate this bias. The test is both ad hoc and vague. Speakers receive no warning whether their contemplated speech extends beyond the parameters of constitutional protection. The test is totally contextual, giving httle guidance to either the speaker or the official censor who must predict the impact of the expression. ${ }^{86}$ For the speaker, this lack of notice fosters continuous uncertainty and thus may chill a risk-averse speaker who desires to minimize his personal legal peril. ${ }^{87}$ Such a person may censor himself by intentionally avoiding those inessages he perceives as approaching the fringe of official acceptability. The official, im turn, must decide when the expression is clearly dangerous and when insufficient time exists for a full and fair hearing of responsive expression that would allow good counsel to defeat bad. ${ }^{88}$ The censor's evaluation involves a two-tiered decision. First, the official must evaluate the speech ideologically to determine whether it is good or evil, because if the speech is good the lack of sufficient time for response is irrelevant. ${ }^{89}$ But under the market model, only the marketplace can accurately separate good froin evil; therefore, no criteria can exist to determine whether speech is sufficiently evil to warrant exclusion from the market. Second, the official must calculate the seriousness of the speech's evil, because the inarket requires greater response time for more serious evils. This requirement forces the official to differentiate without any

expressions delivered to audiences with no special proclivity to be supportive still subjected the speakers to criminal prosecutions.

85. This conclusion should be contrasted with claims that the United States is an open society engaging in a quest for truth. A society cannot claim to be seeking truth wherever it may lead, however, if it tolerates only an appreciation of minor deviations from the established norm. The test of the market process must be "whether it permits criticisin of the fundamental beliefs and practices of the society" and allows such criticism the opportunity to spawn genuine change. T. EMERSON, FirST AMENDMENT, supra note 1, at 16; see also J. MiLL, supra note 5, at 19 ("unless the reasons [for free discussion] are good for an extrelne case, they are not good for any case").

86. Iromically, in another context, Holmes himself realized language's dependence on context. See Towne v. Eisner, 245 U.S. 418, 425 (1918)(“A word is not a crystal, transparent and unchanged, it is the skin of a living thought and may vary greatly im color and content according to the circumstances and time in which it is used.").

87. For an excellent discussion of the government's ability to chill free speech, see Schauer, Fear, Risk and the First Amendment. Unraveling the "Chilling Effect," 58 B.U.L. Rev. 685 (1978).

88. Cf. Dennis v. United States, 341 U.S. 494, 510 (1951)("In each case [courts] must ask whether the gravity of the 'evil,' discounted by its improbability, jnstifies such invasion of free speech as is necessary to avoid the danger.")(quoting the opinion below, United States v. Dennis, 183 F.2d 201, 212 (2d Cir. 1950)(L. Hand, J.)).

89. In such cases courts are likely to refer to the role of free speech in "invit[ing] dispute," "brimg[ing] about a condition of unrest," or "stir[ring] the public to anger." Terminiello v. Chicago, 337 U.S. 1, 4 (1949). When sucl language is used, the lack of "cooling off time" to allow reflection is not considered. 
guidelines between evil counsel that is about to lead an insufficiently educated public astray, and good counsel that merely has convinced an adequately informed public of its "rightness." Under a test with such elasticity, speakers who proclaim any radical political doctrime may expect to receive little or no protection because they will always appear as a threat to the nation and, thus, embody the most serious of all possible evils. ${ }^{90}$ The establishment bias is again obvious.

The clear and present danger test also encourages prolonging debate indefinitely. According to Brandeis, expression inay not be prohibited so long as debate remains ongoing. ${ }^{91}$ Thus, only the process of truth-seeking is fully protected; decisions and actions predicated upon truths once discovered are protected not at all. ${ }^{92}$ Brandeis's approach to the marketplace of ideas accordingly encourages prolonged discussion and, therefore, the delay of decisions that might lead to actions contrary to society's generally accepted "truths." There is, however, hittle value in the discovery of truth that cannot be used as a basis of choice and behavior.

Brandeis's focus on procedural aspects of the market rather than on the substantive actions it triggers also fosters delay in impleinenting any ideas that challenge the status quo perspective. Disputes over the best solutions for societal problems are converted imto disputes over proper marketplace processes. For exainple, rather than focusing on whether the military draft should be reinstated, the debate may well center on whether antidraft groups should be allowed to stage a inassive demonstration in a business district. Such procedural concerns divert attention from the substantive issue so that the status quo is inore easily preserved.

Through this process of transforming substantive conflicts into procedural debates, challengers to the status quo may be placated with a procedural victory while their overt threat is defused. ${ }^{93}$ This shift in focus helps to insulate society from the traunna of having to reconsider its accepted values while at the same time it allows the protesting individual and his supporters to believe that they have a fair opportunity to

90. See M. Shapiro, Freedom of Speech: The Supreme Court and Judicial Review 65 (1966).

91. See Whitney v. California, 274 U.S. 357, 377 (1927)(Brandeis, J., concurring).

92. Cf. id. at 373 "That the necessity which is essential to a valid restriction does not exist unless speech would produce, or is intended to produce, a clear and imminent danger of some substantive evil . . . has been settled.").

93. Cf. T. ARNOLD, THE SYMBols OF GOVERNMENT 34 (1935) ("the function of law is not so much to guide society, as to comfort it"). 
win popular support for their position. ${ }^{94}$ If freedom of expression only gives protection as long as decisions are not yet made, actions are not yet taken, and debate is still im progress, then there is little threat to established norms.

The establishment bias of the clear and present danger test is also apparent when government officials allow speech to enter the market precisely because they presume it will be ignored. For example, when the American Nazi Party fought to march through Skokie, Illinois, 95 that city's Jewish community questioned why the arguments of antisemitism and genocide should be given an opportunity to succeed in the marketplace. ${ }^{96}$ Many media representatives, however, suggested that Skokie's attempt to prevent the march aided the Nazi Party by giving it national publicity im a context $\mathrm{m}$ which the Party was likely to gam sympathy as the underdog. If the Skokie residents had allowed the Nazi Party to march, the media argued, few would know, fewer would care, and still fewer would critically evaluate Party views. ${ }^{97}$ Thus, the risk of the Nazi Party's success could be discounted because its position would be publicly ignored. ${ }^{98}$ In a case like Skokie, then, the marketplace does not function to foster reconsideration of societal norms. The Nazi's expression is allowed precisely because officials an-

94. For a more detailed discussion of how established norms are protected by transforming substantive claims into procedural disputes, see Ingber, Procedure, Ceremony and Rhetoric: The Minimization of Ideological Confict in Deviance Control, 56 B.U.L. REv. 266, 268-73 (1976).

95. See National Socialist Party of Am. v. Village of Skokie, 434 U.S. 1327 (Stevens, Circuit Justice, 1977)(denying stay); National Socialist Party of Am. v. Village of Skokie, 432 U.S. 43 (1977)(per curiam); Collin v. Smith, 578 F.2d 1197 (7th Cir.), stay denied, 436 U.S. 953, cert. denied, 439 U.S. 916 (1978). See generally Goldberger, Skokie: The First Amendment Under Attack by its Friends, 29 MERCER L. REv. 761 (1978).

96. Holmes had argued that all views, even those we detest, need to be given the opportunity to succeed in the narketplace. See Gitlow v. New York, 268 U.S. 652, 673 (1925)(Holmes, J., dissenting).

97. See, e.g., Editorial, Nazis, Skokie, and the A.C.L.U., N.Y. Times, Jan. 1, 1978, § IV, at 10, col. 1 ("The Nazis selected Skokie because they knew that the ensuing protests would give publicity to their miniscule inovement."). Even the Nazis admitted that the sole purpose of their march through Skokie was to draw attention when they otherwise would be ignored by unost people. See Wilson, Nazi Freedom of Speech Challenged, L.A. Times, Oct. 16, 1977, § I, at 6, col. I ("If village officials had let us inarch last April, all of this would be over and forgotten.").

98. Arguably, the public previously had considered the views of the Nazi Party and had rejected thein. Skokie thus may be viewed as a debate about how much more an idea should be tolerated in the marketplace once it has been soundly rejected. There is, lowever, also danger that the market will assume its infallibility, see supra text accompanying notes 22-26, and allow onc generation to decide issues for future generations. C $f$. Lucas v. Forty-Fourth General Assembly, 377 U.S. 713, 737 (1964)(even a majority of voters in a statewide referendunı may not authorize demal of the individual's right to an equally weighted vote). 
ticipate that the marketplace will reject it out of hand. ${ }^{99}$ In contrast, if government officials had perceived the Nazi march as seriously threatening to influence decisions and behavior, they might well have forbidden the march. In precisely those instances when expression threatens to disrupt established power structures and norms, courts have abandoned the market imagery and the clear and present danger test ${ }^{100}$ and have banned the communication. The Supreme Court's regulation of obscenity exemplifies this tendency.

b. Obscenity. In a society allegedly seeking the true or best style of hiving, all pertinent ideas deserve due consideration. "All ideas having even the slightest redeeming social importance . . . have . . . full protection ...."101 The Supreme Court, however, in the 1957 decision in Roth $v$. United States, ${ }^{102}$ viewed obscenity as not deserving societal attention because the Court considered obscenity to be "utterly without redeeming social importance." 103 Consequently, according to Roth, the government does not engage in content discrimmation if it bans obscene inaterial because obscenity is outside the Constitution's protection. ${ }^{104}$

Yet the "redeeming social value" standard is inherently problematic. To whom unust the communication be "redeeming"? 10s Surely the obscene material has social value to people who willingly pay money to

99. Perhaps the Nazi's speech should be rejected snmmarily, see generally Solzhenitsyn, The Exhausted West, HARv. MAG., July-Aug., 1978, at 21 passim, but certainly this attitude contradicts the marketplace's aspirational search for truth.

100. The Court has revised and remterpreted the Holmes/Brandeis "clear and present danger" test since its adoption. See Brandenbnrg v. Ohio, 395 U.S. 444, 447 (1969)(The state may not "forbid or proscribe advocacy of the use of force or of law violation except where such advocacy is directed to inciting or producing imminent lawless action and is likely to incite or produce such action."). More recently, however, the Court has specifically used the language of "clear and present danger" to reverse a court order restraining reporters from publishing allegedly prejudicial pretrial material. See Nebraska Press Ass'n v. Stuart, 427 U.S. 539, 562-63 (1976)(citing United States v. Dennis, 183 F.2d 201, 212 (2d Cir. 1950)(L. Hand, J.,), aff'd, 341 U.S. 494 (1951)); cf. Nebraska Press Ass'n, 427 U.S. at 569 (probability that pretrial pubhicity would work evil was not shown with sufficient degree of certainty to permit prior restraint).

101. Roth v. United States, 354 U.S. 476, 484 (1957).

102. 354 U.S. 476 (1957).

103. Id. at 484.

104. Consequently, Justice Brennan was correct when, in Paris Adult Theatre I v. Slaton, 413 U.S. 49 (1973), he suggested that to replaee the test of "utterly" without social value with one demanding only a lack of "serious literary, artistic, political, or scientific value," Miller v. California, 413 U.S. 15, 24 (1973)(emphasis added), is inconsistent with the analytic underpinnings of Roth . Paris Adult Theatre I, 413 U.S. at 96 (Brennan, J., dissenting); see Schauer, supra note 67, at 929. Under the Miller standard government can no longer claim indifference to content, but must instead evaluate the worth of the speech and the "seriousness" of the ideas presented. See Baker, supra note 1, at 972.

105. See Ginzburg v. United States, 383 U.S. 463, 489-90 (1966)(Douglas, J., dissenting). 
obtain it. ${ }^{106}$ The Court can discount this tautology only by insisting that literature has social value within the marketplace of ideas if it advocates a way of life, and not if it merely entertains those already coinmitted to sucl a life style. ${ }^{107}$ In essence, the Court believes that equating the free exchange of political ideas "with commercial exploitation of obscene material demeans the grand conception of the First Amendment."108

The Supreme Court's opinion in Paris Adult Theatre I v. Slaton ${ }^{109}$ exposed the flaws in this distinction. In Paris Adult Theatre, the Court held that material could be obscene even though it is exhibited only to consenting adults. The interests the state protects through this prohibition include "the quality of life, ... the tone of commerce . . . and, possibly, the public safety itself." 110 States accordingly lave the "power to make a morally neutral judgment" that public exhibition of obscene materials, or commerce in the obscene, tends to "injure the community as a whole" by polluting the "public environment."111 The Court stressed inost veheinently that to grant access to obscene inaterial "is to affect the world about the rest of us." 112

Thus, although the Court has often said that speech is protected precisely because of its role in "the bringing about of political and social changes," 113 it refused to protect obscene material in Paris Adult Theatre predominantly because such material advocates a kind of society the Court finds objectionable. The Court's defense of government regulation of obscenity is based simply on "unprovable assumptions"

106. Richards, supra note 68 , at 79-82.

107. See Baker, supra note 1 , at 971.

108. Miller v. California, 413 U.S. 15, 24 (1973).

109. 413 U.S. 49 (1973).

110. Id. at 58 .

111. Id. at $68-69$.

112. Id. at 59 (quoting Bickel, in On Pornography: II-Dissenting and concurring opinions, 22 PUB. INTEREST 25, 26 (1971)(untitled essay))(emphasis added by the Court).

113. Roth v. United States, 354 U.S. 476, 484 (1957). The obscenity cases, however, may demonstrate that speech may not be permitted to bring about changes that affront upper class propensities. It has been thoughtfully observed that the

journey fron "Ulysses" to Hustler mvolved more than a move fron literature to snut, from words to images. It involves the transition from the preoccupation of an educated minority to the everyday fantasies of the blue-collar majority. . . .

Once upon a time, obscenity was confined to expensive leather-bound editions available only to gentlemen. . . . One of the questions asked by the crown prosecutor [in the trial of the publishers of Lady Chatterly's Lover] . . . was: "Would you let your servant read this book?"

....

Hustler is the servant's revenge.

Neville, Has the First Amendment Met Its Match?, N.Y. Times, Mar. 6, 1977, § 6, pt. 1 (Magazine), at 18, col. 2. 
about what is good for the people. ${ }^{114}$ The Court justifies relying on such unprovable assumptions by comparing them to the assumptions routinely made regarding "good" materials. The Court suggests that because society accepts on faith alone the uplifting quality of good literature and other art forms, so too, states may accept the corresponding assumption that obscenity corrupts and debases. ${ }^{115}$ But the Court's comparison is misplaced, for the state does not and could not compel its adult citizens to read, watch, or listen to such good works. ${ }^{116}$ Offcial determination of what social change is unacceptable and should not be conteinplated is just as antithetical to an open search for truth as is official determination of trutli itself.

Pornography may be beyond constitutional protection, while the Skokie inarch is not, ${ }^{117}$ precisely because judges beheve that pornography is inore likely than Nazi rlietoric to influence community views. ${ }^{118}$ As Professor Laurence Tribe has recognized, current obscenity law seeins incoinpatible with the inarketplace premise that awareness of alteruative views can never be deeined harmful im itself. ${ }^{19}$ Pornography, however, threatens to make us aware of something about ourselves that soine would prefer not to know. "It threatens to explode our uneasy accommodation between sexual impulse and social custom," insists Tribe, and

to destroy the carefully-spun social web holding sexuality in its place. One need not "sound the alarm of repression" in order to argue that the desire to preserve that web by shutting out the thoughts and impressions that challenge it cannot be squared with a constitutional commitment to openness of mind. ${ }^{120}$

c. Summary. Although both the clear and present danger and obscenity standards are rooted in market imagery of an open society searching for truth, they both allow the banning of expression at the point where expression threatens established values. A society that ein-

114. Paris Adult Theatre I, 413 U.S. at 62.

115. Id. at 63.

116. See L. TRIBE, supra note $13, \S 12-16$, at 668 . In addition, the state cannot compel children to read officially determined "good books" if their parents do not cooperate. Cf. Pierce v. Society of Sisters, 268 U.S. 510, 534 (1925)(state statute compelling public as opposed to private education of school children held to interfere unreasonably with parents' liberty to "direct the upbringing and education of [their] children").

117. See supra notes $95-100$ and accompanying text.

118. In fact, the views of those who wished to inarch in Skokie may have been patently unacceptable more because of the marchers' self-professed "Nazism," and all that terin symbolizes, than because of their antisemitic views. For a discussion of the importance of packaging, see infra text accompanying notes 228-33.

119. See L. TRIBE, supra note $13, \S 12-16$, at $669-70$.

120. Id. (footnotes omitted). 
braces such legal doctrines cannot claim to be open-minded in its search for truth. The following section considers whether these repressive doctrines are produced by a biased system gone amuck or whether the marketplace itself is inherently flawed.

2. Truth As Socialization. Although the assumption of the existence of objective truth is crucial to classic marketplace theory, almost no one believes im objective truth today. ${ }^{121}$ Historians, for example, first determine what type of historical data to seek and then determine the relevance of the data they find. Thus, history is founded on the selective perception of historians rather than on any objective historical truth. 122 The same can be said for the pursuit of trutl $\mathrm{m}$ any academic, scientific, or professional disciplime. ${ }^{123}$ The "truth" of a theory depends on its ability to explaim a phenomenon to the judging individual's satisfaction and on its aestlietic appeal to that imdividual. ${ }^{124}$ Today's truth, consequently, may become tomorrow's superstition. ${ }^{125}$

That the marketplace reveals truth, or even the best solutions, is further belied by the lack of any consensus in this country on what is true or best. If the marketplace actually revealed truth, diversity and conflict presumably would diminish rather than increase. ${ }^{126}$ But, because people's perceptions are based on their varying interests and ex-

121. Cf. Baker, supra note 1, at 974 ("Truth is not objective."). "Platonic forms" are no longer credibly sought. See id. (the "moderns appear unwilling to believe in platonic forms"). Their deficiency as a value sourcc is that their content or accuracy cannot be tested. In addition, those people who attenupt to build a value system upon universals are trapped in a dilemma: either the alleged universal ends are too few and abstract to aid in deciding specific conflicts, or they are too numerous and concrete to be truly universal. See R. UNGer, KNowledge \& Politics 254-56 (1975).

122. See R. Berkhofer, A BeHavioral Approach To Historical ANalysis 23-26 (1969). American accounts in high school textbooks of the 'Revolutionary War' need only be compared to their English counterparts' discussion of the 'War with the Colonies' to denonstrate how two cultures can have a significantly differing understanding of the same event.

123. See Baker, supra note 1, at 974; see also T. KuHN, THE STRUCtURE OF Sclentific RevoLUTIONs passim (2d ed. 1970).

124. See Baker, supra note 1 , at 974 . For a discussion of the role of nodels, see Ingber, A Dialectic: The Fulfilment and Decrease of Passion in Criminal Law, 28 RuTGers L. Rev. 861, 861-62 (1975); Ingber, supra note 75, at 328-29.

125. Consider the response given to Nicolaus Copernicus, Galileo Galilei, and Giordano Bruno for challenging the Aristotilean/Ptolemaic vision of the universe. See 6 ENCYCLOPEDIA BRITANNICA 463 (1971)(Copernicus withheld publication of his work until shortly before his death); 9 id. at 1089-90 (Galileo placed under house arrest until his death and forced to recant the Copernican system); 4 id. at 308 (Bruno burned at the stake for his challenges to Aristotilean physics and astronomy). Their beliefs, contrary to the "relevant" evidence and circumstances of the time, questioned the very core of their cultures. Astronomers and liunianists alike, lowever, now view that era's truth as crude superstitution.

126. See Baker, supra note 1 , at 967. 
periences, ${ }^{127}$ their perceptions are not likely to be socially homogenized. Consequently, as long as people have differing experiences, there is little guarantee that any society can agree on what is "true," 128 and diversity and conflict will likely persist. ${ }^{129}$

People seldom want to read or hear that which is contrary to their convictions. Nor are they usually open to criticisms of groups to which they belong. To the contrary, it is difficult for a person to reject ideas, opinions, and positions as being false when they coincide with his own interests or when they appeal to his lialf-submerged prejudices. ${ }^{130}$ Consequently, if people's perspectives are not hoinogeneous, a person will perceive the inarketplace as leading to the best result only if it favors those who, in that specific individual's view, should be favored. In short, if the preconceived perspectives of individuals are inherently heterogeneous, then their decisions on the proper outcome of the market competition actually are made prior to that purported competition. Consequently, the very market process reputed as the only way to determine which perspective should win inerely reflects the preexisting

127. Even language and syntax are forces that structure, direct, and limit individual perception. For years ethnologists studying the relation of language to culture have insisted that any change in language influences both perception and conception. See, e.g., R. Brown, 1. CopI, D. Dulaney, W. Frankena, P. Henkle \& C. Stevenson, Language, Thought \& Culture 1-25 (1958); E. SAPIR, Language, in Culture, LANGUAGE, AND Personality 7 passim (1949); Whorf, The Relation of Habitual Thought and Behavior to Language, in LANGUAGE, CULTURE AND PERSONALITY: EsSAYS IN MEMORY OF EDWARD SAPIR 75 (L. Spier, A. Hallowell \& S. Newman eds. 1941). Edward Sapir, an early leader in ethnology, has written that

[t] he relation between language and experience is often misunderstood. Language is not merely a more or less systematic inventory of the various items of experience which seen relevant to the individual, as is so often naively assumed, but is also a self-contained, creative symbohic organization, which not only refers to experience largely acquired without its help but actually defines experience for us by reason of its formal completeness and because of our unconscious projection of its implicit expectation into the field of experience.

Sapir, Conceptual Categories in Primitive Languages, in LANGuage in Culture and Society 128, 128 (D. Hymes ed. 1964).

128. Furthermore, dialogue cannot end divergences in perspective if people have differing experiences and conflicting interests. Both logic and reason lack perspective; thus, they cannot alone justify value choices. Although logic and reason may help to indicate consistency within a chosen value systen, see Ingber, supra note 75, at 320; Weyrauch, Book Review, 25 STAN. L. REv. 782, 800 (1973), the selection of the values to be pursued unust precede the effective use of rationahity. Reason standing alone is either an empty source for the determination of values or a cainouflage to conceal fiagrantly elitist value preferences. See Ely, The Supreme Court, 1977 Term-Foreword: On Discovering Fundamental Values, 92 Harv. L. Rev. 5, 33-39 (1978); cf. Tushnet, “. . . And Only Wealth Will Buy You Justice"-Some Notes on the Supreme Court. 1972 Term, 1974 WIs. L. REv. 177, 177 ("the Court found constitutional flaws in legislation that it disapproved on policy grounds, while it found no flaws in legislation that it approved").

129. Social life has great diversity and conflict in individual needs, interests, and experiences, which may explain why there are more, and more conflicting, paradigms for social relations than is the ease for "scientific" phenomena. Baker, supra note 1, at 974.

130. See Wellington, supra note 1 , at 1130 . 
perspectives of the market participants. ${ }^{131}$ The marketplace process in fact changes little.

Conflicts in the marketplace, therefore, are not likely to lead to conclusive agreement on what is "true" or "best." Rather, the inarketplace serves as a forum where cultural groups with differing needs, interests, and experiences battle to defend or establish their disparate senses of what is "true" or "best." Official adoption and support of one group's position, allegedly due to its success in the marketplace, merely enhances through legal mechanisms the stature of that group's subculture; it does not represent a universal acceptance of that group's perspective.

Accordingly, it is difficult to treat free speech as uniquely essential to the discovery of truth or to the encouragement of informed choice. Experience more likely provides the information needed to confront life's exigencies than does speech. Rather than being fostered by mere expression, societal change depends more on the growth of new interests, needs, and experiences which are used to view sensory data differently so as to gain new perspectives from which status quo conditions may be challenged. Such growth requires a governmental and social system that nurtures new experiences and interests and, consequently, divergent notions of truth. In such a system, expression would be important only if it helped to create differing environments suited to the self-fulfillment of people with contrasting perspectives.

In the Umited States today, however, most behavior, experiences, and life-style choices are fully subject to governmental influence and restriction. Neither our federal nor local governments are under any obligation to encourage the diversity of experiences necessary for a society open to change. On the contrary, both levels of government promote conformity and consensus by controlling the developnient of "proper" perspectives. Through its authority over economic, political, educational, and social conditions, and its superior position in data gathering and dissemination, our government actively participates in the socialization of the citizenry. Contrary to the marketplace image of independent citizens freely choosing among competing ideas, ${ }^{132}$ the

131. See supra text accompanying notes $26-29$.

132. Even Mill himself, in discussing liberty, saw the limits of his philosophy:

It is, perhaps, hardly necessary to say that this doctrine is meant to apply to human

beings in the maturity of their facilities. We are not speaking of children, or of young persons below the age which the law may fix [for inajority]. . . . Those who are still in a state to require being taken care of by others, must be protected against their own actions .....

J. MiLL, supra note 5, at 9. Little remains of freedom of choice, however, if a public education system socializes the great majority of our children for 12 years and has a self-admitted role in forming "good citizens." Mill stated, but did not recognize, the conflict in his theory: 
government strongly encourages the public to favor or disfavor certain views.

Through processes of socialization, government predisposes the individual to accept some perspectives rather than others. Government inculcates ideas that tend to protect existing interests, prevailing values, and current attitudes. ${ }^{133}$ In short, the government strongly encourages the public to choose those ideas within the market that preserve the status quo. The public school systein, combined with conpulsory education, is one of many effective inechanisms for governmental socialization and indoctrination.

As far back as Brown v. Board of Education, ${ }^{134}$ the Court acknowledged that state sponsored education was a major force im the socialization of children. ${ }^{135}$ Public schools, scholars have noted, ${ }^{136}$ provide a potent forum for state indoctrination: first, the audience's attendance is compulsory, and the histeners do not yet have the independent knowledge or psycliological sophistication necessary for critical evaluation of what their teachers tell them; ${ }^{137}$ second, public schools package their

Society has had absolute power over [its members] during all the early portion of their existence: it has had the whole period of childhood and nonage in which to try whether it could make them capable of rational conduct in life. The existing generation is master Id. at 73 .

both of the training and the entire circumstances of the generation to come . . . .

The educational system may thus indoctrinate a value-set precisely to skew later norinative judgments. This social indoctrination, however, may be essential to give a person the frame of reference necessary to actively participate in governmental and social decisions; without some normative structure, a person would be no inore than a passive receptor of sensory impulses. It is, in any case, too simplistic to view this process of sociahization as being controlled by devious, manipulating educators. See Ingber, supra note 124, at 870.

133. See T. EMERSON, FreEdom OF Expression, supra note 1, at 289; $c$. Kamenshine, The First Amendment's Implied Political Establishment Clause, 67 CALIF. L. Rev. 1104, 1104 (1979)(proposing that first amendment be interpreted to include prohibition against political establishment in order to alleviate government's power to indoctrimate citizens).

134. 347 U.S. 483 (1954).

135. Id. at 493 ("Today [pubhic education] is a primcipal instrument in awakening the child to cultural values....").

136. See Yudof, When Governments Speak: Toward a Theory of Government Expression and the First Amendment, 57 TEx. L. REv. 863, 875 (1979); see also Kamenshine, supra note 133, at 1134.

137. A comparison of Abington School Dist. v. Schempp, 374 U.S. 203, 224-25 (1963), with West Virginia State Bd. of Educ. v. Barnette, 319 U.S. 624, 641 (1943), adds soune insight. In Schempp the Court held unconstitutional state laws and practices requiring the recitation of a prayer in the public schools. 374 U.S. at 205. The fact that individual students could request to be excused from the exercises furnished no defense. Id. at 224-25. The Court recognized that the school child's age and immaturity likely would make it difficult for him to publicly express his wish to act differently from his classmates; a subtle but strong pressure would exist for the child to conforn. See id. at 289-90 \& n.69 (Brennan, J., concurring). In Barnette the Court held unconstitutional a school practice requiring students to pledge allegiance to the United States flag even if the child did not wish to do so. But, the Court required only that the school permit the students to excuse themselves. Barnette, 319 U.S. at 630 . Unlike its decision in Schempp, the Barnette Court 
message as highly valued education rather than as less trustworthy advertisement; 138 third, the children are likely to be impressed by the adult teacher's authority and seemingly vast fund of knowledge; ${ }^{139}$ and, finally, teachers mete out rewards and punishments to those who do or do not appropriately learn the lesson of the day. ${ }^{140}$

A less jaded view of the "indoctrination" that takes place in our educational institutions emphasizes the necessity of "selectivity" in any school system. In his dissent in Board of Education v. Pico, ${ }^{141}$ a decision that imposed first amendment limits on a local school board's discretion to renuove books from junior and senior high school libraries, Justice Rehnquist stressed that,

of necessity, elementary and secondary education must separate the relevant from the irrelevant, the appropriate from the inappropriate. Determining what information not to present to the students is often as important as identifying relevant material. This winnowing process . . . is fundamentally inconsistent with any constitutionally required eclecticism in public education. ${ }^{142}$

Although Justice Brennan's plurahty opinion in Pico limited the school board's ability to renuove library books, it also readily approved the indoctrination role of educational institutions:

We are . . . in full agreement . . . that local school boards must be permitted "to establish and apply their curriculum in such a way as to transmit community values," and that "there is a legitimate and substantial community interest in pronioting respect for authority and traditional values be they social, moral, or political."143

permitted the ritual to continue although the pressure to conform certainly would be as great. Regardless of Justice Jackson's admirable language in the Barnette decision, 319 U.S. at 641-42, the Constitution apparently allows subtle political indoctrination even if sucl religious indoctrination is prohibited. A state inay even refuse to certify teacliers not trusted to socialize youngsters to a particular set of norms. See Ambach v. Norwich, 441 U.S. 68, 78-80 (1979)(New York law upleld which denied certification of alien teachers in public schools if alien eligible for U.S. citizenship but declines to seek it).

138. That allegedly educational communication can also be intended to propagandize is most obvious in the legislation of some states requiring courses contrasting the "good" democratic form of government with the "bad" communist regimes. In Florida, for example, instructors inust einphasize the American economy as producing "higher wages, higher standards of living, greater personal freedom and liberty than any other systein of econoinics on earth," FLA. STAT. $\$$ 233.064(4) (1981), while focusing upon the "dangers of Communisın, the ways to fight Communism, the evils of Communism, the fallacies of Communism, and the false doctrimes of Communisin." FlA. STAT. \$233.064(5) (1981). Consider also the recent furor over the rapidly growing and controversial nuclear education inovement in American schools. See Nuclear War Becomes Hot Topic in Schools, Wall St. J., May 24, 1983, at 1, col. 1.

139. I ain reminded of the vehenence with which my 15-year-old son will defend an erroneous factual statement made by one of his teachers.

140. See Yudof, supra note 136, at 875 .

141. Board of Educ. v. Pico, 457 U.S. 853, 904 (1982)(Rehnquist, J., dissenting).

142. Id. at 914 (einphasis in original); see Nagel, supra note 18 , at 333 .

143. Board of Educ. v. Pico, 457 U.S. 853, 864 (1982)(quoting Brief for Petitioners at 10). 
Although the Court distinguished removing books froin refusing to acquire them in the first place, the loss of perspectives contained in the books is just as dainaging under the inarket model whether the school removes books or initially rejects them. Surely the Court would deem a school board's decision not to purchase books written froin a Black or Republican perspective unconstitutional. Yet refusal to acquire books suggesting a Jewish infiltration of our government likely would not raise a judicial eyebrow. The difference clearly seeins to be the cultural acceptance of one perspective and rejection of the other. Consequently, public schools shape children's attitudes through such selective exposure and thereby predispose children to accept certain established perspectives as adults. ${ }^{144}$

Thus, as the educational indoctrination process deinonstrates, socialization mechanisms can subtly influence people to separate "fashionable" trends of thought from the "unfashionable" without any signs of formal censorship. ${ }^{145}$ No expression need be forbidden overtly, no matter how challenging it inay be to the existing order, for socialization processes will prevent it froin effectively penetrating the inass consciousness of the citizenry. ${ }^{146}$

Meinbers of the judiciary, responsible for uploolding the values protected by the first amendment, are not immune from the saine processes of socialization and indoctrination that predispose the general public to certain perspectives. The members of the courts are, after all, as much creatures of their culture as are we all. ${ }^{147}$ Given this inevi-

144. Of course, if a child's parents disapprove of the public school system and can afford to finance the alternative, they can opt out and place their child in a private educational institution. See Pierce v. Society of Sisters, 268 U.S. 510, 534-35 (1925). Exercise of this constitutional privilege, however, may be not only expensive, but beyond the means of many parents. Economic reality, combined with coinpulsory education, may force those who are not well off, and therefore have the least objective reasons to be committed to established values, to leave their children in educational institutions that promote establishment values.

145. Alexander Solzhenitsyn suggested this perspective on American culture in a speech given before the Harvard commenceinent in 1978. See Solzhenitsyn, supra note 99, at 23 ("Nothing is forbidden, but what is not fashionable will hardly ever find its way imto periodicals or books or be heard in colleges. Legally, your researchers are free, but they are conditioned by the fashion of the day.").

146. See Goodwin, The Shape of American Politics, Commentary, June 1967, at 25, 32 ("Ours is one of the most ideological nations of all. The very absence of serious and widespread public debate proves how successfully ideas have been woven into our national life.").

147. See Desmond, The Federal Courts and the Nature and Quality of State Law, in THE FuTURE OF FEDERALISM 87, 89 (S. Sliuinan ed. 1968)(" the great tides of currents which engulf the rest of men do not turn aside in their course and pass the judges by" ")(quoting Benjamin Cardozo). Judges are normally affected by the normative culture surrounding government officials; indeed, judges tend to be drawn from roughly the same rank as legislators. See J. ELY, DEMOC- 
table socialization of the judiciary, marketplace ideals become unrealistic and serve only as a legitimizing myth for a system that encourages the presentation of a limited range of preselected ideas rather than the open-minded evaluation it purports to foster. ${ }^{148}$ Speech outside the range of acceptable norms ${ }^{149}$ has, not surprisingly, been frequently curtailed with judicial approval. ${ }^{150}$ Jurists, like other citizens, are likely to hear and take seriously only those opinions that do not too openly contradict their own. ${ }^{151}$

\section{B. The Assumption of Rationality.}

Once one recognizes that the marketplace assumption of objective truth is implausible and that truth and understanding are actually no more than preconditioned choice, one is prompted to reevaluate otlier marketplace assumptions in order to compreliend the marketplace tlieory's persistence. Foremost among these assumptions is that people can distmguish rationally between a message's substance and the distortion caused by its form and focus. Altlough the implausibility of the public's ability to separate the form of a message from its substance

RACY AND DiSTRUST 57 (1980). If, due to their positions, judges are socialized differently than legislators, such differences may be problematic. See Nagel, supra note 18, at 334:

It is at best unclear why the normally sedate and highly controlled atmosphere of a courtroom is thought to be a good traming ground for appreciating the dynamics of vigorous public debate. In contrast, pohitical involvement and accountability provide much of the experience that one might expect would lead to a useful understanding of the requirements of a system of free speech.

148. This theme will be more fully developed infra in Part IV.

149. Polsby labeled this range the "community agenda of alternatives" in 1963. N. POLSBY, Community Power and Political Theory 135 (2d ed. 1980); see id. at 133-35; see also Deutsch, Neutrality, Legitimacy, and the Supreme Court: Some Intersections Between Law and Political Science, 20 STAN. L. REv. 169, 254 (1968); Ingber, supra note 75, at 344. The "commumity agenda of alternatives" is the universe of alternative decisions that the dominant cultures in society accept as possible outcomes from the inarketplace debate; within this range there are of course both preferred and unpreferred alternatives. Although the legal system may not support alternatives outside that agenda without a severe loss of legitimacy, it may symbolically support an unpreferred alternative within the agenda without engendering such dangers. For a fuller discussion of this concept, see infra text accompanying notes 361-63.

150. For decisions in which the Court upheld convictions under statutes limiting controversial speech as not mconsistent with the first amendment, see, for example, Dennis v. Umited States, 341 U.S. 494, 516 (1951); Debs v. United States, 249 U.S. 211, 215 (1919). See also New York v. Ferber, 458 U.S. 747, 774 (1982)(upholding a state law outlawing child pornography).

151. Acculturation or socialization may partially explain some of the obscenity decisions in which the Supreme Court imposed its own "enlightened" position of selective tolerance for the tastefully salacious coupled with contempt for the coarsely vulgar. Indeed, the distinction between Stanley v. Georgia, 394 U.S. 557, 568 (1969)(protecting exhibition of obscene films in the home), and Paris Adult Theatre I v. Slaton, 413 U.S. 49, 67 (1973)(forbidding pubbic display of obscene films), coincides with a distinction between polite society and the hoi polloi. To protect the showing of a privately produced movie on a privately owned projector while prosecuting the exhibition of an identical film in a public theatre smacks of economic and cultural discrimination. For further discussion of the impact of the Jnstices' socioeconomic background upon their receptivity to various styles of speech, see Justice Breunan's dissent in FCC v. Pacifica Found., 438 U.S. 726, 776-77 (1978)(Brennan, J., dissenting). 
will be demonstrated below, ${ }^{152}$ some legal doctrine has, nevertheless, developed that attempts to limit irrational responses to communications by controlling the form in which such messages are presented.

1. A Problem of Form. In Chaplinsky v. New Hampshire, ${ }^{153}$ the Court denied first amendment protection to ideas packaged in a patently insulting manner. In upholding the conviction of a Jehovah's Witness who had gotten into a fight on a sidewalk with the city marshal after calling him "a God damned racketeer" and "a damned Fascist,"154 Justice Murphy, writing for a unanimous Court, commented:

There are certain well-defined and narrowly limited classes of speech, the prosecution and punishment of which have never been thought to raise any constitutional problems. These include the lewd and obscene, the profane, the libelous and the insulting or "fighting" words-those which by their very utterance inflict injury or tend to incite an immediate breach of the peace. ${ }^{155}$

During the decades smce Chaplinsky's attempt to distimguish between protected and unprotected classes of speech, substantial first amendment problems have arisen under the categories of the "profane" and the "libelous." 156 The "fighting words" category, in contrast, consistently has reinained beyond the constitutional pale. ${ }^{157}$ One set of authors finds the regulation of "fightimg words" consistent with free speech theory because such words trigger an automatic reaction rather than cognitive reflection. ${ }^{158}$ Consequently, removal of such speech from the marketplace, according to these authors, only ehminates thoughtless and irrational responses; ${ }^{159}$ httle of value is lost, and public order is preserved.

152. See infra text accompanying notes $178-232$.

153. 315 U.S. 568 (1942). In Chaplinsky, the state court had interpreted the state statute to ban "face-to-face words plainly likely to cause a breach of the peace by the addrcssee." Id. at 573. Because the addressee here was a Marshal, surely the court could have insisted that a state law enforcement officer be stringently required to refrain from responding to such speech through a breach of the peace.

154. Id. at 569.

155. Id at 571-72.

156. For the Court's present view on "profanity," see Lewis v. City of New Orleans, 415 U.S. 130, 134 (1973)(1nunicipal ordinance prohibiting cursing, reveling or use of obscene language struck down as overbroad); Burstyn, Inc. v. Wilson, 343 U.S. 495, 506 (1952)(unconstitutional censorship of an allegedly "sacrilegious" movie). The modern view of libel is illustratcd by New York Times Co. v. Sullivan, 376 U.S. 254 (1964), and Garrison v. Louisiana, 379 U.S. 64 (1964). But see Beauharnais v. Illinois, 343 U.S. 250, 266 (1952)(suggesting libel outside scope of first amendment)(as receutly as 1978, Justice Blackmun cited Beauharnais as good law in an opinion joimed by Justice Rehnquist, see Smith v. Collin, 436 U.S. 953 (1978)(mein.)(Blackmun, J., dissentimg), denying stay of, 578 F.2d 1197 (7th Cir. 1978)).

157. See Lewis v. City of New Orleans, 415 U.S. 130, 133 (1974); Gooding v. Wilson, 405 U.S. 518,522 (1972).

158. J. Nowak, R. Rotunda \& J. Young, Constitutional LAW 789 (1978).

159. Id. 
The Supreme Court's "provocative speaker/hostile audience" doctrine is closely related to the fighting words doctrine. In Feiner v. New York, ${ }^{160}$ the Court, recognizing the state's ability to suppress a provocative speaker likely to rouse spectator violence against himself and his supporters, affirmed the disorderly conduct conviction of a soap box orator who ignored a police command to cease speaking to a racially mixed crowd. ${ }^{161}$ The orator had given the impression that he was "endeavoring to arouse the Negro people against the whites, urging that they rise up in arms and fight for equal rights."162 The two policeinen on the scene confronted a crowd of about eighty people. At least one individual threatened violence if the police did not act to stop the speaker. ${ }^{163}$ Althougli the threat of violence came from a spectator opposed to the speaker, Chief Justice Vinson insisted that when a speaker "passes the bounds of argument or persuasion and undertakes incitement to riot, [the police must not be] . . . powerless to prevent a breach of the peace." 164 Again the explanation for suppression was that the speech did not encourage rational discourse, but ratler had passed the "bounds of persuasion."

Despite the Court's attempts to explain the "fighting word" and "provocative speaker/hostile audience" doctrines in terms of protecting the rationality of the marketplace, tliese doctrines are inconsistent with the Court's other articulations of the marketplace model. For instance, as early as 1949 the Court insisted in Terminiello v. Chicago ${ }^{165}$ that

a function of free speech . . . is to invite dispute. It may indeed best serve its high purpose when it induces a condition of unrest, creates dissatisfaction with conditions as they are, or even stirs people to anger. Speech is often provocative and challenging. It may strike at prejudice and preconceptions and have profound unsettling effects as it presses for acceptance of an idea. . . . [T] he alternative would lead to standardization of ideas either by legislatures, courts, or dominant political or community groups. ${ }^{166}$

But what distimguishes suppressible fightimg words from protected provocative words that stir opponents to anger? Socially valuable dissent often is phrased in unconventional terms and frequently offends polite

160. 340 U.S. 315 (1951).

161. See id. at 316-18, 321 .

162. Id. at 317. Feiner also had described the President as a "bum," the mayor of Syracuse as a "champagne-sipping buin," and the American Legion as a "Nazi Gestapo." Id. at 330 (Douglas, J., dissenting).

163. Id. at 317 .

164. Id. at 321.

165. 337 U.S. 1 (1949).

166. Id. at 4. 
standards of discourse. The distinction inerely seems, at timcs, to forbid "low" styled speech froin a "low" statured speaker. This "class" focus only further entrenches a bias for established norms and respectable proponents. ${ }^{167}$

Yet the focus on form is an inevitable outgrowth of Chaplinsky's attempt to separate protected from unprotected speech. Chaplinsky suggests that the essence of a communication can survive a governmental purge of the disturbing form im which the communication is presented for public consideration, 168 but many critics have rejected the assumption that the content and form of speech somehow are separable. ${ }^{169}$ Yet the inarketplace model makes this very assumption. It

167. The civil rights movement of the 1960's demonstrated the danger of the Feiner doctrine because opposing spectators atteinpted to use the doctrine to suppress civil rights deınonstrations by claiming that bystanders' emotions would be uncontrollably aroused. The inarches and speeches of Dr. Martin Luther King and others through certain southern communities surely were as likely to lead to violence from hostile audiences as were the acts of Feiner. The civil rights movement, however, had the support of established groups throughout much of the country outside of the southern states. It is therefore unsurprising that the Supreine Court has consistently distinguished Feiner on its facts, although the Court has never technically ovcrruled it. E.g., Gregory v. City of Chicago, 394 U.S. 111, 112 (1969)(civil rights dcınonstration); see also Bachellar v. Maryland, 397 U.S. 564, 567 (1970)(antiwar demonstration); Cox v. Louisiana, 379 U.S. 536, 551 (1965)(citing Feiner but distinguishnig it as a "far cry" " from the civil rights demonstration involved in the instant case); Edwards v. South Carolina, 372 U.S. 229, 236 (1963)(civil rights deinonstration; a "far cry from the situation" in Feiner). Upon comparing these cases it becomes obvious that when a speaker has greater stature and his cause commands greater support from established groups, courts will less likely suppress his speech as solicitous of the irrational; mstcad, in these cases the courts imterpret the first amendment to "include vehcincnt, caustic, and soinetimes unpleasantly sharp attacks on government and public officials." New York Tiınes Co. v. Sullivan, 376 U.S. 254, 270 (1964).

168. See Chaplinsky, 315 U.S. at 571-72 (some utterances are "no essential part of any exposition of ideas"). This is the basic postulate behind the Court's opinion in FCC v. Pacifica Found, 438 U.S. 726 (1978)(FCC may regulate radio broadcasts that use indecent but not obscene language). The Court insisted that a "requirement that indecent language be avoided will have its primary effect on the form, rather than the content, of serious commumication. Thcre are few, if any, thoughts that cannot be expressed by the use of less offensive language." Id. at 743 n.18.

169. See, e.g., L. TRIBE, supra note $13, \S 12-8$, at 606 . Justice Brennan stressed this point in his Pacifica dissent:

The idea that the content of a message and its potential impact on any who inight receive it can be divorced from the words that are the vehicle for its expression is transparently fallacious. A given word may have a unique capacity to capsule an idea, evoke an emotion, or conjure up an image.

FCC v. Pacifica Found., 438 U.S. 726, 773 (1978)(Brennan, J., dissenting).

Strangely enough, only seven years earlier in Cohen v. California, 403 U.S. 15 (1971), the Court had precisely recognized the importance of an expression's packaging to its emotive force. In holding that the first amendment protects the wearing of a jacket bearing the words "Fuck the Draft" in a courthouse corridor, Justice Harlan acknowledged that

much linguistic expression serves a dual communicative function: it conveys not only ideas capable of relatively precise, detached explication, but otherwise inexpressible emotions as well. In fact, words are often chosen as inuch for their emotive as their cogintive force. We cannot sanction the view that the Constitution, while solicitous of the cognitive content of individual speech, has little or no regard for that einotive func- 
presumes people can use reason to focus on the substance of a message and to distinguish and reject the emotional and irrational appeals of its packaging. Evidence from the social sciences has established and emphasized the irrational elements of persuasion ${ }^{170}$ and, thus, seriously challenges this marketplace assumption. As Professor C. Edwin Baker has recognized, emotional appeals, whether rational or not, are highly potent: " 'subconscious' repressions, phobias, or desires influence people's assimilation of messages; and, most obviously, stimulus-response mechanisms and selective attention and retention processes influence understanding or perspectives." 171 These processes, coupled with the phenomenon of cognitive dissonance, ${ }^{172}$ insulate individuals from messages mconsistent with those perspectives that further their perceived self-imterests. ${ }^{173}$ Marketplace outcomes therefore are determined more by the packaging of the message and the psychological

tion which, practically speaking, may often be the more important element of the overall message sought to be communicated.

Id. at 26 (emphasis added).

A comparison of Cohen and Pacifica illustrates the judicial ambivalence toward the irrational. In upholding Cohen's right to wear his jacket in a courthouse, Justice Harlan's opinion recognized that many people would find offensive much valuable speech that awakens the public to outrages to which it had been blind. Yet in Pacifica, the Court approved the FCC's ban of satiric humorist George Carlin's 12 minute monologue, called "Filthy Words," froin daytime radio. The Justices were unable to appreciate that there are those "who think, act, and talk differently from the Members of this Court, and who do not share their fragile sensibilities." Pacifica, 438 U.S. at 775 (Brennan, J., dissenting).

The Court's attempt to distinguish Pacifica from Cohen is unconvincing. See Pacifica, 438 U.S. at 747 n.25. Although the seven "filthy words" broadcast could enter the privacy of one's home, such "imvasion" would only happen if an imdividual decided to histen to the broadcast; radios have both an on-off switch and a number of frequencies froln which to clloose. Notwithstandimg the fact that children could have listened to the broadcast without parental knowledge or permission, if Carlin's monologue would have been protected had it been made on a public street in the presence of children, it should not have been any less protected when delivered over radio waves. Although the Court's language focuses on the broadcast's timing and form rather than its substance, the Court's divergent analyses in Cohen and Pacifica suggest that substantive considerations were relevant. Apparently, in 1968 during a heated public debate about the Vietnam War and the military draft, when credible and recognized public leaders were divided over the issues, one could signal one's position with passionate and emotively colorful language. It would therefore appear that when the substance of a communication has the approval of powerful social forces, as in Cohen, the Court inay give more flexibility to the form the message takes than it would if established groups disapprove the message, as in Pacifica.

170. See, e.g., K. MANNheIM, Ideology AND Utopia passim (1954); C. Mill, The Structure of Power in American Society, in Power, Politics AND People 23, 23 (I. Horowitz ed. 1963); C. Mill, The Cultural Apparatus, in id. at 405, 405-06; C. Mill, On Knowledge and Power, in id. at 599, 609-11; Baker, supra note 1, at 976-78.

171. Baker, supra note 1 , at 976 .

172. See generally infra note 429 and accompanying text (discussion of cognitive dissonance).

173. See Baker, supra note 1, at 977. 
predispositions of the listeners than by any rational process. ${ }^{174}$ Consequently, the market model's reliance on public rationality is, at best, misplaced. ${ }^{175}$

Other scholars also liave perceived the marketplace model's questionable reliance on rationality. They stress, however, that the marketplace's fairness, ratler than its ultimate wisdom, justifies its continued acceptance. ${ }^{176}$ A fairness justification, nevertlieless, fails because establishment groups dominate the market. These groups have greater access to the marketplace's most effective mechanisnis for information dissemination, and also possess the power to legally curtail beliavior that might result in new ideas and perspectives threatening to their interests. ${ }^{177}$

2. A Problem of Access and Style. The first amendment developed in a society where the major forms of public debate were handprinted leaflets, liand-set newspapers, and speeches in town ineetings ${ }^{178}$ and public parks. With roughly equal decibels and tongues, people competed for attention and approval using their wit, persistence, and eloquence. Because of this conparative equal access, the most powerful threat to free speech and a free press came froin government censor-

174. Because there is no assurance that the individual with the "true" or "best" perspective will be the superior rhetorician, this point is particularly crucial. The decisionmaker who frankly conveys the limitations and uncertainty of his position may find that others are more willing to follow the denagogue who professes to offer certainty and truth. See, e.g., W. Golding, LoRD of THE FLIES 134-92 (1954). For a discussion of the skill of persuasion-or the importance of the packaging of a message dehivered by a lawyer, see Ingber, supra note 75, at 329-30.

175. Consider, for example, the constitutional protection of commercial speech as a feature of the marketplace model. See generally Bates v. State Bar, 433 U.S. 350 (1977); Virgimia State Bd. of Pharmacy v. Virginia Citizens Consumer Council, 425 U.S. 748 (1976). In Limmark Assocs., Inc. v. Township of Willingboro, 431 U.S. 85, 97 (1977), for example, the Court struck down a township ordinance prohibiting the posting of real estate "For Sale" and "Sold" signs. The ordinance was designed to stem the flight of white homeowners from a racially integrated community. Id. at 86. The Court assumed that homeowners who were wavering whether to sell their houses would act rationally when, in fact, real estate agents may have been banking on emotive responses. Id. at 95-96. By recognizing the consumers' and homeowners' right to receive messages from advertisers, id. at 92 , the Court upheld the advertiser's right to psychologically manipulate the baser traits of such individuals.

176. See, e.g., A. BiCKel, The Morality of Consent 62 (1975)("The social interest that the First Amendinent vindicates is . . . the successful operation of the pohitical process, so that the country may better be able to adopt the course of action that conforms to the wishes of the greatest number, whether or not it is wise or is founded in truth.").

177. See Baker, supra note 1, at 978. See generally Baker, Counting Preferences in Collective Choice Situations, 25 UCLA L. REv. 381 (1978).

178. See A. Meiklejohn, Political Freedom 24 (1960). Meiklejohn's concept of deinocracy requires that every voter, not just administrators or legislators, be given "the fullest possible participation im the understanding of those problems with which the citizens of a self-governing society must deal." Id at 75 . His image is more akin to participatory democracy, such as the town meeting, than to representative deinocracy. 
ship or suppression. ${ }^{179}$ Brandeis's statement about good counsel counteracting bad ${ }^{180}$ assumes the continued existence of equal access and the correspondingly limited role of the first amendment. Historically this assumption may have been accurate; today, however, it is indefensible.

The expansion of governmental powers and the creation of a bureaucracy possessing vast quantities of information and expertise have made the government, rather than individual citizens, the most pervasive participant in the inarketplace. ${ }^{181}$ Most of the information and views available for consideration within the marketplace coine from government itself. Aided by increasingly subtle ineans of social control, ${ }^{182}$ the government's power to overwhelm or block alternative views from the inarket ${ }^{183}$ threatens the theoretical basis of consensual government. ${ }^{184}$

Theoretically, however, two methods exist for communicating nonsanctioned views to the public: the mass commumication media for those with access, and the public forum ${ }^{185}$ for those without such inedia access. This section examines whether either of these mechanisins effectively conveys perspectives other than those of dommant societal groups.

179. Cf. Police Dep't v. Mosley, 408 U.S. 92, 95 (1972)("above all else, the First Amendment means that government lias no power to restrict expression because of its message, its ideas, its subject matter, or its content").

180. Whitney v. California, 274 U.S. 357, 375 (1927)(Brandeis, J., concurring).

181. See generally Emerson, supra note 75.

182. See supra notes 133-51 and accompanying text.

183. Government need not even allow the press or the public access to many state facilities. See, e.g., Houchins v. KQED, Inc., 438 U.S. 1, 9 (1978)(reversing lower court injunction ordering prison officials to grant the press access to certain prison facilities). Such a ruling can easily frustrate many attempts to gain infornation or understanding unskewed by governmeutal selection or interpretation.

184. See Yudof, supra note 136 , at 865 . To be fair, government speecl may also provide a necessary check on the ability of large corporations to dommate the communications networks. See id. at 866 .

185. Professor Harry Kalven, Jr. first developed the concept of the public forum. See Kalven, The Concept of the Public Forum: Cox v. Louisiana, 1965 SuP. CT. Rev. 1. Much writing lias followed in his wake. See, e.g., Horning, The First Amendment Right to a Public Forum, 1969 Duke L.J. 931; Kamin, Residential Picketing and the First Amendment, 61 Nw. U.L. REv. 177, 207-16 (1966); Nahmod, Beyond Tinker: The High School as an Educational Public Forum, 5 HARv. C.R.-C.L. L. REv. 278 (1970); Stepliensou, $A$ Seat on the Sidelines: The Georgia Appellate Judiciary and the Public Forum, 3 GA. L. REv. 80 (1968); Steplienson, State Appellate Courts and the Political Process: Florida and the Public Forum, 23 U. MIAMI L. Rev. 182 (1968); Wexler, Dissent, the Streets and Permits: Chicago as Microcosm, 2 URB. LAW. 350 (1970); Zillman \& Imwinkelried, The Legacy of Greer v. Spock: The Public Forum Doctrine and the Principle of the Military's Political Neutrality, 65 GEO. L.J. 773 (1977); Comment, The Public Forum from Marsh to Lloyd, 24 AM. U.L. REv. 159 (1974). 
a. The mass media. No one today seriously would argue that -picketing and leafleting are as effective communication devices as newspapers and broadcasting. ${ }^{186}$ Access to the mass media is crucial to anyone wishing to dissemmate his views widely. Nevertheless, monopolistic practices, ${ }^{187}$ economies of scale, and an unequal distribution of resources have made it difficult for new ventures to enter the business of mass communications. ${ }^{188}$ Restriction of entry to the econoinically advantaged quells voices today that might liave been heard in the time of the town meeting and the painphleteer. ${ }^{189}$ The media consequently carry great power to suggest and sliape articulated tliought. ${ }^{190}$ Media owners and managers, ratler than the individuals wishing to speak,

186. See Barron, supra note 73, at 1647. A 1974 survey of 490 prouninent cducators, labor leaders, bankers, business people, members of Congress, government officials, and clergy rated television the most powerful institution in the country. The White House was second and the Supreme Court third. Who Runs America? A National Survey, U.S. NEws \& WoRLD REP., Apr. 22, 1974, at 30. But cf. Jaffe, The Editorial Responsibility of the Broadcaster: Reflections on Fairness and Access, 85 HARv. L. Rev. 768, 769-71, 787 (1972)("The implication that the people of this country . . . are mere unthinking automatons manipulated by the media, without interests, conflicts or prejudices is an assumption which I find quite maddening.").

187. As early as the middle 1950 's, $94.3 \%$ of the daily newspapers in the United States did not face competition froun rival daily publications. See Nixon, Who Will Own the Press in 1975?, 32 Journalism Q. 10, 13 (1955), eited in F. THAyer, Legal Control of the Press $\S 22$, at 130 (4th ed. 1962). The Supreme Court has recognized the FCC's legitimate concern in limiting this concentration of power in the broadcast media. See FCC v. National Citizens Comm. for Broadcasting, 436 U.S. 775, 799 (1978).

188. Cf. F. THAYER, supra note 187, at 128:

When large inetropolitan newspapers are valued at figures running into millions of dollars and when even a nonunetropolitan daily in a city of less than 25,000 population may represent a valuation of $\$ 350,000$ to $\$ 1,250,000$, it is not easy to establish a new newspaper in such a community or to buy an already established daily.

189. In Miami Herald Publishing Co. v. Tornillo, 418 U.S. 241 (1974), the Court acknowledged this restrictive image of the marketplace:

The obvious solution, which was available to dissidents at an earher time when entry into publishing was relatively inexpensive, today would be to have additional newspapers. But the same economic factors which have caused the disappearance of vast numbers of inetropolitan newspapers, have inade entry into the inarketplace of ideas served by the print media almost impossible.

Id. at 251 (footnote omitted).

190. Television exercises this power to shape thought to a greater extent than does the primt media because of marked differences in the audiences of the two inedia forns. First, those who often read tend to be more educated than those who do not. This is true not only for patrons of books and relatively sophisticated periodicals, but also for readers of pictorial and general interest magazines. Yet, those with less education tend to watch nore television news. Robinson, American Political Legitimacy in an Era of Electronic Journalism: Reflections on the Evening News, in Television as a Social force: New Approaches to Television Cruticism 105, 107 (D. Cater \& R. Adler eds. 1975). Second, television viewers do not tend to supplennent one medium with another. Generally, the more time readers spend with newspapers, the more time they will spend with magazines and books. Television viewers, however, tend to use other media less as they watch television more. $I d$. at 108-09. In other words, public reliance on the print inedia has been mitigated by the readers' education and their exposure to a variety of publishcd information. Bccause these factors do not affect television viewers, as television becounes more dominant 
thus determine which persons, facts, and ideas sliall reacli the public. ${ }^{191}$ Accordingly, those facts, ideas, and perspectives most likely to gain media access and, consequently, large scale public exposure, are those appealing to the self-interest of those individuals and groups who own and manage the media, to the mass audience whose patronage provides the economic and political basis for advertising, ${ }^{192}$ and to economic organizations whose commercial payments directly provide funds for the media. ${ }^{193}$ Because all these groups tend to embrace estabhshed values and traditional perspectives, ${ }^{194}$ media managers are unlikely to disseminate frequently those ideas most challenging to conventional wisdom and the established power structure. ${ }^{195}$ The granting of media access accordingly is fraught witl status quo biases.

in supplying the public with news and information, the diversity and wealth of the marketplace decreases precipitously.

191. In 1969, then Vice-President Spiro Agnew announced that "the American people should be inade aware of the trend toward the monopolization of the great public information vehicles and the concentration of more and unore power [over public opinion] in fewer and fewer hands." N.Y. Tinnes, Nov. 2I, 1969, at 22, col. 2-3. Ironically, given Agnew's conservative political affiliation, the "New Left" was making the same argument when it insisted that the system of freedons of expression favored the status quo, particularly through establishment control of the inass media. Cf. T. Emerson, Freedom of EXPression, supra note 1, at 726 (noting several New Left lines of attack upon freedom of expression). See generally Marcuse, Repressive Tolerance, in R. WolfF, B. Moore \& H. Marcuse, A Critique of Pure Tolerance 81 passim (1965).

192. Television, for example, with its overt commercial interest in pursuing the largest audience, is inevitably pressured to shut out ideas displeasing to some and substitute the bland least common denoninators antagonizing to no one. See J. BARRON, supra note 16, at 84. Like other content restrictious, this television inarketing strategy may distort the market and leave the public with incomplete and perhaps inaccurate perceptions of the social and political universe.

The inedia's fear of libel suits also causes content restrictions that encourage mediocrity. In Gertz v. Robert Welch, Inc., 418 U.S. 323, 347 (1974), the Supreme Court limited first amendment protection in many types of defamation suits. The Gertz decision intensified the media's incentive to confine its coverage to "safe" issues by giving maximum protection only to publishers or broadcasters whose seuse of news does not extend beyond a combination of officialdom and matters relating to "public figures," that is, persons who already have attracted media attention. Id. at 344-47. Reporters that stray farthest from "mainstream issues" accordingly feel the threat of libel suits inost acutely.

193. See Media and the First Amendment in a Free Society 79-80 (Georgetown Law Journal ed. 1972); Baker, supra note 1, at 979-80.

194. Cf. Coluunbia Broadcasting Sys. v. Denuocratic Nat'l Comm., 412 U.S. 94,187 (1973) (Brennan, J., dissenting)("in the commercial world of mass communications, it is simply "bad business' to espouse-or even to allow others to espouse-the heterodox or the controversial"); Baker, supra note 1, at 980 (inedia owners, advertisers, and the mass audience all support the status quo); Canby, The First Amendment Right to Persuade: Access to Radio and Television, 19 UCLA L. REv. 723, 727 (1972)(fairness doctrime tends to encourage "bland mixture of views on each station"); Jaffe, supra note 186, at 773 n.26 (media editors avoid controversial stands which would trigger FCC "equal time" requireinents).

195. Those groups powerful enough to control the media probably attamed that position in the community only by conforming to the values of the community. The media, therefore, is not likely to support and articulate criticism of the fnndamental beliefs and practices of society. Robert Wolff, in critiquing American life and politics, observed that "we find a strange nixture of the greatest tolerance for what we inight call established groups and an equally great intolerance for 
Protection against governmental interference with the press, therefore, does not guarantee, as it did in the past, that an individual with something to say will have effective access to an audience. Private interests can thwart the free exchange of ideas allegedly protected by the first amendment as easily as can the government. ${ }^{196}$ In short, even if the first amendment erected a wall between the government and the marketplace, the inere existence of mass media controlled largely by interests committed to established values and traditional perspectives limits the forums available for challenges to existing power structures.

Furthermore, the media's actual impact on the consuming public also reinforces rather than challenges traditional notions. Although it popularly is believed that the inedia significantly can alter and shape people's attitudes and behavior, social science research largely dispels this myth. Such researcl imstead demonstrates that press and broadcast inedia are nost effective when they reinforce established perspectives. ${ }^{197}$ They effectively create new opinions only when the audience has no conflicting preexisting belief to defend through selective perception. ${ }^{198}$ To be successful, however, status quo critics must alter people's preexisting beliefs. In this endeavor, use of the mass media is least effective. ${ }^{199}$ Thus, even if the problems of unequal access were eliminated, a status quo bias would be promoted by the skewed impact of the mass media. Because government communications dominate the marketplace and mass media cannot or will not effectively disseminate dissident views, challengers to established status quo perspectives are left only with resort to public forums.

b. The public forum. For over forty years the courts have recognized the public's right to use public foruuns-streets, parks, and open places-for mcetings, parades, deinonstrations, and canvassing. ${ }^{200}$

the deviant individual." Wolf, Beyond Tolerance, in R. WOLFF, B. MOORE, \& H. MARCuse, supra note 191, at 3, 37.

196. See Associated Press v. United States, 326 U.S. 1, 20 (1945)("Freedoin of the press from governmental interference . . . does not sanction repression of that freedoun by private interest."); cf. Marsh v. Alabama, 326 U.S. 501, 509 (1946)(holding that states could not, under the first and fourteenth amendments, permit "a corporation to govern a community of citizens so as to restrict their fundamental liberties").

197. See Canby, supra note 194, at 739-41, and authorities cited therein.

198. See Klapper, Communication, Mass: Effects, in 3 International Encyclopedia of THE Social Sciences 81, 82-85 (D. Sills ed. 1968).

199. Professor Baker's discussion of modern social science research supports the conclusion that the nuass media often fails to persuade people to change preexisting beliefs. See Baker, supra note 1 , at 979.

200. See Hague v. CIO, 307 U.S. 496, 515-16 (1939). 
These alternative forums for public communication enable dissenting or low status individuals and groups to disseminate their views even when they cannot gain access to mass media. The mass public demonstration, for example, conveys an image of power to bystanders and participants alike, reinforces the group's commitment to its cause, allows participants to register publicly tlieir opimion, and appears to circumvent the elite's power to control inass communication. ${ }^{201}$ Furthermore, public deinonstrations have a different impact on the audience than do newspapers or broadcasts. The audience's experience in a face-to-face encounter is more imposing than when it passively reads about or listens to a viewpoint. The intercliange is inore flexible, more of the senses are engaged, and the audience's response, whether negative or positive, is likely to be inore pronounced. As Professor Emerson has written, "the public asseinbly has a dynamic quality achieved by no other form of communication." 202

The Supreme Court, however, consistently has viewed the right to use a public forum as relative, rather than absolute; the right inust be exercised "in subordination to the general coinfort and convenience, and in consonance with peace and good order."203 The inass demonstration, as well as effectively dissemmating ideas, often has an unsettling impact upon a community. Conflicts arise over the use of space and the rights of nonsympathizers to avoid contact with deinonstrators. The emotional feedback generated by face-to-face contact designed to evoke or increase support also may build antagonisins and lead to violence. ${ }^{204}$ Not surprisingly, the Court consistently has held that such activities as the use of loud sound trucks, mass deinonstrations controlling limited space, or parades disrupting traffic flow are subject to regulation. According to the Court, however, only the conduct incidental to the communication, the "speech-plus," can be regulated; the content of the communication itself cannot be the target of the regulation. ${ }^{205}$ In

201. Whether mass demonstrations in fact accomplish this result is arguable. See infra text accompanying notes 205-27, 394-96.

202. See T. EMERSON, FREEDOM OF EXPRESSION, supra note 1, at 286.

203. Hague v. CIO, 307 U.S. 496, 516 (1939).

204. "Freedom of expression implies controversy," insists Professor Emerson,

and in [the public demonstration] the controversy takes place in the public arena. It

often involves large masses of people, hostile forces opposing each other face to face,

high emotions, and unforeseeable consequences. Street meetings, demonstrations, and

other public assemblies are not always guided by the canons of middle-class politeness;

they may be rough, aggressive and turbulent.

T. EMERSON, FREEDOM OF EXPRESSION, supra note 1, at 288.

205. Justice Goldberg, writing for the majority in Cox v. Louisiana, 379 U.S. 536 (1965), emphatically rejected the notion "that the First and Fourteenth Amendments afford the same kind of freedom to those wlo would communicate ideas by conduct sucl as patrolling, narching or picketing on streets and highways, as these amendments afford to those who communicate ideas by 
general, the state may place reasonable time, place, or ma1mer restrictions on speech in a public forum, ${ }^{206}$ but officials must implement these regulations without regard to the content of the speech. ${ }^{207}$ The Court has justified such restrictions because they allegedly are content neutral. In effect, however, they are not.

The Court's distimction between fully protected "pure speech" and "speech-plus," which is subject to reasonable regulation, significantly affects the type of ideas conveyed, the nature of the speaker, and the intensity with which views may be communicated. For example, because dissidents and the economically disadvantaged rely more heavily than do status quo supporters on street demonstrations for public expression of their views, regulation of such demonstrations, although facially content neutral, restricts the public's access to views cliallenging the status quo. ${ }^{208}$ Therefore, the regulation of public forums further biases the marketplace in favor of establishment views by restricting the primary inethod dissidents use to communicate their criticisms. ${ }^{209}$

The recent case of Heffron $v$. International Society for Krishna Consciousness ${ }^{210}$ exemplifies the disparate impact of time, place, and manner restrictions on nonestablishment groups. In Heffron the Supreme Court upheld a state's restriction of the distribution and sale of literature, and the solicitation of donations at a Minnesota state fair to as-

pure speech." Id. at 555; see also Adderley v. Florida, 385 U.S. 39, 48 (1966)(rejecting the premise that "people who want to propagandize protests or views have a constitutional right to do so whenever and however and wherever they please").

206. Not all places are public forums. No matter how convenient, syntbolically significant, or necessary for effective communication a place may be, it may not be a public forun if it is privately owned and used for purposes other than public debate and discussion, e.g., Hudgens v. NLRB, 424 U.S. 507, 519-20 (1976), if it is publicly owned but not dedicated to public discussion, e.g., Greer v. Spock, 424 U.S. 828, 838 (1976); Adderley v. Florida, 385 U.S. 39, 47, (1966), or if, while dedicated to discussion, it is limited to a certain method of communication, e.g., United States Postal Serv. v. Greenburgh Civic Ass'ns, 453 U.S. 114, 128-29 (1981)(access to inailboxes unay be limited to communications that have traveled through the federal nails). But see Grayned v. Rockford, 408 U.S. 104, 118-21 (1972)(public school grounds); Brown v. Louisiana, 383 U.S. $131,142-43$ (1966)(plurality opinion dictuin)(branch public library). For a discussion of whether government can limit public debate neerely by restricting certain areas and thus determining that they are not public forums, see infra text acconspanying notes 215-19.

207. See United States v. Grace, 103 S. Ct. 1703, 1707 (1983); Perry Educ. Assn. v. Perry Local Educators' Assn., 103 S. Ct. 948, 955 (1983); Heffron v. International Soc'y for Krishna Consciousness, 452 U.S. 640,648 (1981).

208. Critics of the Vietnam War, for instance, depended nuch nore on mass rallies to convey their perspective than did the war's supporters; the supporters included nany public officials who had ample access to the mass media.

209. For example, restricting the use of sound trucks in residential areas because of noise or in commercial districts because of obstruction may mean that those living and working in these areas will never hear the dissident's message.

210. 452 U.S. 640 (1981). 
signed booths within the fairgrounds. The fair sponsor rented space to all apphicants on a first-come, first-served basis. ${ }^{211}$ The rule applied equally to nonprofit, rehgious, charitable, and commercial enterprises. The Court found the regulation justified as a means of maintaining orderly crowd movement. ${ }^{212}$

Although the regulation was content neutral on its face, it effectively limited dissemination of ideas to those that fairgoers affirmatively sought by approaching a booth. Fairgoers, however, are much more likely to seek information from dominant and established groups about which they are knowledgable and with which they identify. ${ }^{213}$ Such groups tend to confirm rather than challenge the fairgoers' perspectives. Consequently, the marketplace of ideas at the fairground was structured to reduce the impact of dissenting views and increase the market force of dommant status quo perspectives. ${ }^{214}$

Nevertheless, the Supreme Court has suggested that the equal access doctrine eliminates any marketplace bias in the public forum: ${ }^{215}$

211. The fair's sponsor charged a rental fee based on the size and location of the booth. $I d$. at 644. The propriety of the fee was not argued before the Court, but such a fee could lead to the physical segregation of poor groups at less frequented fairground locations.

212. Id. at 654 .

213. The Court has acknowledged implicitly that it is unlikely that individuals will affirmatively seek out views that question those they already hold. See Tinker v. Des Moines Indep. Community School Dist., 393 U.S. 503, 513 (1969)("Freedoin of expression would not truly exist if the right could be exercised only in an area that a benevolent government has provided as a safe haven for crackpots.").

214. Dissenting in Adderley v. Florida, 385 U.S. 39 (1966), Justice Douglas argued that [t]hose who do not control television and radio, those who cannot afford to advertise in newspapers or circulate elaborate pamphlets may have only a more limited type of access to public officials. Their nethods should not be condemned as tactics of obstruction and harassment as long as [they] are peaceable.

Id. at 50-51 (Douglas, J., dissenting).

In spite of Justice Douglas's advice and the disproportionate impact of the Minnesota regulation upon groups and views deviating from the norm, the Heffron Court refused to compel the state to consider other less restrictive means to protect the flow of fairgoer novenient, such as penalizing disorderly or disruptive conduct, limiting the number of solicitors, or placing nore narrowly drawn restrictions on the location or novenent of the representatives of various groups. The Court was willing to accept, untested, the assumption that the proposed alternatives would be less effective. See Heffron, 452 U.S. at 654 . In addition, the Court was not concerned that certain communication would be less effective imder the state regulation. Id. at 654-55. Apparently the Court viewed any legitimate state interest as a higher priority than the commumicative interests of the Krishnas and other such groups.

215. Although a total ban on channels of communication involving "speech-plus" wonld clearly have a content specific impact, the case law is ambiguous as to whether such a total ban would be vahd or whether the Constitution inandates some "minimum access" to the marketplace. An "equal access" approach does not require courts to compel communities to dedicate any particular space to public discourse and assume all the attendant dangers and costs. A "minimum access" theory would require such judicial action. "Equal access" merely accepts the decisions of the community as to the time, place, and manner of public discourse to be allowed and apphes those decisions even-handedly to unpopnlar as well as popular groups and viewpoints. The many 
once a public forum is open for one viewpoint or subject, opposing views and alternative subjects must be granted equal access for comparable uses.216 Given the professed purposes and importance of the first amendment, the Court's focus on "equal access" sliould be a inatter of some concern. If the Court emphasizes the equal access doctrine, it may invite government to "equalize" access by totally banning the use of specific forums to all speakers rather than by lifting the restrictions froin soine. ${ }^{217}$ Indeed, a total ban on a specific public foruin is conceivable if the forum is not essential to dissemination of established viewpoints and the increased cost of alternative communication for such viewpoints is outweighed, in the minds of their supporters, by the damage done to dissidents who cannot easily afford or gain access to other communication channels. Consequently, altlough the equal access doctrine superficially protects against inarketplace bias in public forums, the doctrine could restrict a dissident's access to the public and, thereby, further bias the entire marketplace in favor of the establishment. Thus, rather than preventing marketplace bias, equal access to public forums only dispels the appearance of a skewed and manipulated inarketplace. As deinonstrated above, ${ }^{218}$ liowever, government regulations need not discriminate overtly against specific viewpoints to assure that those liaving ineaningful access to the inarketplace of ideas will espouse traditional values.219 Consequently, the Court's reliance on the equal access doctrine to preserve self-government, "trutll" discovering, and individual developinent, simply is misplaced.

c. Symbolic conduct. Individuals or groups lacking access to the print and the electronic media may atteinpt to gain media attention by staging a "inedia event." If a large group holds a inass denionstration it may gam media coverage. Unfortunately, many individuals with

public forum decisions that focus on vagueness and overbreadth, e.g., Carey v. Brown, 447 U.S. 455, 470-71 (1980); Hynes v. Mayor of Oradell, 425 U.S. 610, 620 (1976); Lovell v. City of Griffin, 303 U.S. 444, 451-52 (1938), suggest an "equal access" theory. These decisions concentrate on governmental discretion and censorship in distributing access rather than on problems of lack of access.

216. Some authors have assumed that equal access would unite the interests of the politically powerful with those of minority or dissident groups and thus significantly protect all viewpoints from interference. Dean John Hart Ely luas characterized this approach as one of "virtual representation." J. ELY, supra note 147, at 84; see Kalven, supra note 185, at 30; see also Emerson, supra note 75, at 802-03 (discussion of equal protection). See generally Karst, supra note 9, at 20 (discussion of equal access through equal protection).

217. See Blasi, Prior Restraints on Demonstrations, 68 MrCH. L. Rev. 1481, $1492-97$ (1970); cf. Palmer v. Thompson, 403 U.S. 217, 226 (1971)(closure of public swimming pools after desegregation order not violation of equal protection).

218. See supra notes 186-217 and accompanying text.

219. See supra text accompanying notes $132-51$. 
views they wish to share simply cannot organize a mass demonstration. A speaker can broaden support for his views through a mass demonstration only if a large number of persons already share his opinions. Without prior and meaningful access to the marketplace, however, such a following is difficult to obtam.

Individuals with perspectives not popular enough to support a mass demonstration may still gam media attention through symbolic acts. For example, during the Vietnam War many young men expressed their objection to the war effort and the draft by burning their draft cards in violation of federal laws. ${ }^{220}$ They argued that their dramatic behavior was necessary to compensate for lack of media access. These young men imsisted, therefore, that their acts were communications ${ }^{221}$ protected by the first amendment. 222

When the Supreme Court confronted the issue in United States $v$. O'Brien, ${ }^{223}$ however, Chief Justice Warren rejected the view "that an apparently limitless variety of conduct can be labeled 'speech' whenever the person engaging im the conduct intends thereby to express an idea."224 Instead, Warren insisted that when "speech" and "nonspeech" elements are combined in a single course of conduct, "a sufficiently important governmental interest in regulating the nonspeech

220. For an account of the draft-card burnings and the background of the federal laws passed in 1965 outlawing them, see Alfange, Free Speech and Symbolic Conduct: The Draft-Card Burning Case, 1968 SuP. CT. REv. 1. The relevant provisions of the Selective Service Act, which have not been substantially amended since 1965, are in 50 U.S.C. app. \$ 462(b)(3) (1976)(penalizing any person "who . . . knowingly destroys, knowingly inutilates, or in any inanner changes any such certificate"); the corresponding Selective Service regulations are in 32 C.F.R. $\$ \S 1617.1,1623.5$ (1967)(current relevant regulations, which do not provide for issuance of certificates to registrants, codified at 32 C.F.R. $\S \S 1615.1-.9,1621.1-.2(1983)$ ).

221. Both the Court and some court critics have tried at times to draw a line between protected speech and unprotected conduct. See, e.g., United States v. O'Brien, 391 U.S. 367, 376 (1968); T. EMERSON, FREEDOM OF EXPRESSSION, supra note 1, at 9. As Professor Tribe has argued, however, the difficulty with the distinction is that it does not exist:

All communication except perhaps that of the extrasensory variety involves conduct.

Moreover, if the expression involves talk, it nuay be noisy; if written, it may becoune hitter.

So too, much conduct is expressive . . . . Expression and conduct, nuessage and nue-

dium, are thus inextricably tied together in all communicative behavior; expressive be-

havior is " $100 \%$ action and $100 \%$ expression."

L. TRIBE, supra note $13, \S 12-7$, at $599-600$ (footnotes omitted).

222. Peter Kiger, for example, burned his draft card and then pleaded a first amendment defense to the court. Kiger contended that his act was newsworthy only because it was a criminal act. United States v. Kiger, 297 F. Supp. 339 (S.D.N.Y. 1969), affd, 421 F.2d 1396 (2d Cir.), cert. denied, 398 U.S. 904 (1970); see J. BARRON, supra note 16, at 120-22. Kiger argued that television newsworthiness is determined by potential dramatic impact. See id. In Kiger's case, WCBS-TV gave him instant access to the airwaves for burning his card, access which was not otherwise available because CBS had refused to sell spot advertisements for social or political opinions. Id. at 121.

223. 391 U.S. 367 (1968).

224. Id. at 376 . 
element can justify incidental limitations on First Amendment freedoms."225 The Court then upheld the anti-draft-card-burning legislation, finding that it furthered many of the goals and purposes of the selective service system. ${ }^{226}$

Under the O'Brien Court's analysis of symbolic conduct, as long as the governinent does not directly suppress the "communicative element," it may prohibit or control all other aspects of such "expression."227 But, if the protestimg mdividual has no meaningful method of communication other than the prohibited symbohc conduct, his view effectively is silenced while the governunent's apparent neutrality is perpetuated. Consequently, the legal doctrine surrounding "symbohic conduct," like the legal doctrine supporting "speech-plus," scarcely is neutral in the contest between stability and change. Furthernore, when these doctrines are coupled with dissidents' restricted access to mass inedia and the regulation of public forums, it becomes evident that the first amendment does not give a public voice to those advocating unpopular positions.

d. Dissidence and unconventionality. Dommant viewpoints of established groups need little protection given our constitutional schenre. Electoral accountability ensures that almost all persons who regularly disassociate themselves or interfere with expression of these dommant views cannot obtaim or hold public office. The disadvantaged outsiders who lack the power or stature necessary to gain polit-

225. Id at $376-77$.

226. O'Brien, 391 U.S. at 376-77. Justice Harlan, concurring scparately, stressed that O'Brien did not show that alternative, equally effective, ways of expressing his message were unavailable. Id. at 389 (Harlan, J., conenrring). Given this society's alleged commitunent to the marketplace of ideas, one wonders why Justice Harlan did not place the burden on the state to show that O'Brien had realistic alternatives. Furthermore, the Court's dccision did not even compel the state to deinoustrate the lack of a less restrictive means of fulfilling its stated purposes. At most, the state showed that the "communicative element" of O'Brien's conduct had not been gratuitously inhibited. See Ely, supra note 62, at 1484-85 ("gratuitous inhibition" is the term Dean Ely adoptcd to express the Court's requirement that the restriction must further a legitimate governmental interest).

227. In O'Brien, the Court created a fonr-part test to determine whether government regulation of symbohic speech was justified:

[1] if it is within the constitntional power of government; [2] if it furthers an important or substantial government interest; [3] if the government interest is unrelated to the suppression of free expression; and [4] if the incidental restriction on alleged First Amendment

freedoms is no greater than is essential to the furtherance of that interest.

O'Brien, 391 U.S. at 377 . If the government interest is related to the commnmicative content of the conduct, Brandenburg v. Ohio, 395 U.S. 444 (1969), and not O'Brien, is the controlling decision. E.g., Tinker v. Des Moines Indep. Community School Dist., 393 U.S. 503, 510, 511 (1969)(school authorities unay not forbid students frown wearing black armbands symbolizing opposition to the Vietnam War while allowing the wearing of other symbols of political or controversial signifcance). For a comparison of $O^{\prime} B r i e n$ and Tinker, see generally Ely, supra note 62, at 1491 . 
ical influence through conventional inethods of organization and communication also are those who typically test the limits of free expression. The first amendment protections are inost crucial to such outsiders. 228

Yet an anomaly exists im our system of free expression. Although the rhetoric surrounding the first amendment purports to protect all expression, 229 our laws are, at best, essentially indifferent to creating opportunities for expression. ${ }^{230}$ Telling an unpopular speaker that he will mcur no criminal penalty for his expression is of little value if he has no effective means of disseminating his views. A right that cannot be meaningfully exercised is, after all, no right at all. ${ }^{231}$ Because our marketplace has severely restricted those inputs inost challenging to the status quo, 232 the resulting outputs similarly are skewed to favor estabhished views.

Because dissidents' access to the public is effectively constrained through both legal doctrines and private control of unass communication, dissident groups that wish to question the fundamental beliefs and practices of society must often use unconventional ineans and teruns to

228. Yet, the courts "have certainly not decided to shape and use the law to protect those weaker groups and weaker critics who cannot rely on wealth or power over public opinion as their safeguard." Riesman, Democracy and Defamation: Fair Game and Fair Comment II, 42 Colum. L. REv. 1282, 1310-11 (1942).

229. But see supra notes $25-53$ and accompanying text (discussion of communications outside first amendment such as obscemity). The rhetoric rarely acknowledges the exception for obscenity, which is perceived by the Court as being outside the ambit of the first amendment. See Roth v. United States, 354 U.S. 476, 485 (1957).

230. Consequently, Herbert Marcuse could argue that,

with the concentration of economic and political power and the integration of opposites [e.g., government and press] in a society which uses technology as an instrument of dommation, effective dissent is blocked where it could freely emerge: in the formation of opinion, im information and communication . . . . Under the rule of monopolistic media-themselves the mere instruments of economic and political power-a mentality is created for which right and wrong, true and false are predefined wherever they affect the vital interests of the society.

Marcuse, Repressive Tolerance, in R. WOLFF, B. MOORE, \& H. MARcuse, supra note 191, at 95.

231. This perspective has been accepted by the Supreme Court in other areas of law. For example, the Court has sought to guarantee that all classes of citizens may exercise their right to counsel. See, eg., Gideon v. Wamwright, 372 U.S. 335, $344-45$ (1963)(sixth amendment requires states to provide imdigent felony defendants competent legal counsel). Justice Harlan warned that decisions of this nature tend "to read into the Constitution a philosophy of leveling that would be foreign to many of our basic concepts of the proper relation between government and society." Douglas v. California, 372 U.S. 353, 362 (1963)(Harlan, J., dissenting). In a society fearful of this sort of leveling, however, the rights of the poor may be theoretical at best. $C f$. Deutsch, supra note 149 , at $190 \mathrm{n} .78$ (discussing whether or not constitutional right to attend private schools depends in practical sense on ability to bear such financial burden).

232. See Z. Chafee, Free Speech in the United States 559 (1941). Any attempt to bypass the media and enter the market through mass demonstrations, soundtrucks, and the like faces increased governmental control through regulation of "speech-plus" and "symbohic conduct." See supra notes $200-27$ and accompanying text. 
reach the public's awareness. It is therefore easier to understand, if no easier to sympathize with, those who must resort to disruptive, even violent, conduct to make their grievance known im the marketplace. Such has been the history of all major social and political movements in this country. ${ }^{233}$ Yet, the public must evaluate the content of the dissident's message while remaining impervious to any associated disruptive conduct if the market is to remain rational.

As noted above, ${ }^{234}$ the public's ability to separate a inessage's packaging from its substance is, at best, doubtful. The public tends to focus inore on the dissenting message's packaging than on its content precisely because of the dissident's unconventional personality, nethod of communication, and terminology. In fact, the public hostility and anxiety created by unconventional and disruptive presentations compound the difficulty the audience has in understanding, or even perceiving, the imtended message. In contrast, orthodox positions generally are heard from respected "responsible" imdividuals in "responsible" contexts, thereby increasing their acceptability to the public. In order to gain acceptance by the public, the dissident must thus overcolne both a socialization systen that predisposes the public against unconventional perspectives, as well as a negative response to his inessage's packaging. The inarketplace is, therefore, skewed to afford status quo views greater opportunity for public exposure and acceptance. It is hardly likely that the public will give dissident views a "rational" evaluation in this marketplace.

\section{The Marketplace as a Self-Fulfilling Prophecy.}

The marketplace of ideas is more myth than reahity. ${ }^{235}$ In practice, comununications flowing into the market largely reflect conventional political, economic, and social points of view. Many would-be speakers gam only severely restricted access to the market, and diversity of perspective is largely nonexistent. In reality, the marketplace is hardly the laissez-faire type of free market the model suggests. Some critics, explaining its continuing viability, have noted that the marketplace functions as a self-fulfilling prophecy. ${ }^{236}$

233. For example, recall the "Black Revolution" of the 1960's and the Boston Tea Party.

234. See supra notes $169-227$ and accompanying text.

235. The myth that the marketplace is open to ideas of social criticism and change has supphed the courts with a justification to approve the outlawing of behavior perceived as dangerous to norms and values embraced by dominant groups. See, e.g., Dennis v. United States, 341 U.S. 494,501 (1951)('Whatever theoretical merit there may be to the argument that there is a 'right' to rebellion against dictatorial governments is without force where the existing structure of government provides for peaceful and orderly change.").

236. Baker, supra note 1 , at 980 . 
Despite the aforementioned flaws, to those who accept traditional values and conventional wisdom the market seems to be functioning successfully. Because dominant groups espousing established perspectives have relatively complete access to the market and find their views largely adopted by the public, they, unlike dissidents, do not perceive marketplace outcomes as predetermined, or as strongly influenced by socialization, access, or packaging. Because the perspectives that dominant groups think "best" are quite likely adopted, to those who adhere to dominant beliefs the marketplace does seem to reach the best result. Therefore, the marketplace model provides a dominant group with a basis for its self-serving belief that the dominance of its perspectives is justified.237 This byproduct of the market model might in turn explain the marketplace theory's persistence despite its serious and obvious malfunctions.

Dissidents, who have experienced only restricted access to the marketplace, and little if any success in it, will of course not see the market process as arriving at the best perspectives. Marketplace theory is, in the minds of some dissidents, nothing but an ideological construct designed to deflate protest and delude the populace into believing that it, rather than an elite, controls its destiny. ${ }^{238}$ Such dissidents perceive stronger and more strident expressions or actions as necessary to overcome these market failures. Consequently, neither holders of dominant views nor dissidents need feel pressured to alter their views in light of market outcomes.

Although some dissidents believe the marketplace inevitably is biased and thus should be rejected, others who believe that free expression preserves individuality continue to support marketplace imagery. ${ }^{239}$ This latter group stresses the need for marketplace reform, to assure equal access to all. ${ }^{240}$ Such cries for reform are, however, not limited to those uttered by dissidents.

\section{REFORMING THE MARKET}

To correct the imbalance in perspective that the marketplace offers to the public and to aid the effective advocacy of dissident, underprivileged, and unorganized groups or imterests, ${ }^{241}$ Professor Jeroine Barron, almost two decades ago, argued for a first amendment right of

237. Id.

238. This was the view of Marcuse. See supra note 230 (quoting Marcuse).

239. See, e.g., Baker, supra note 1, at 980-81.

240. See, e.g., id.

241. According to one critic, "enormous freedom exists for the press, but [due to unequal access], not for the readership." Solzhenitsyn, supra note 99, at 23. 
access. ${ }^{242} \mathrm{He}$ questioned the worth of a right to speak if, because of the unpopularity of the message or the poverty of the speaker, no viable forum existed. This argument is reminiscent of Meiklejohn's assertion twenty years earlier that by the words of the first amendment, "Congress is not debarred from all action upon freedom of speech. Legislation which abridges that freedom is forbidden, but not legislation to enlarge and enrich it." 243 Thus, a first amendment tightrope becomes apparent: government intrusion into the marketplace may lead to unacceptable governmental control and media censorship, ${ }^{244}$ yet governinental refusal to regulate the media may permit those with political and economic influence to mamtain private control of the major channels of commumication. Either outcome defeats free expression as envisioned by the marketplace model of the first amendment. Despite the danger of government censorship, however, the Supreme Court has encouraged presentation of, and has at times approved of, market reform proposals. 245

\section{A. Reform Proposals.}

By creating various access rights, reformers hope to give dissenting mdividuals or groups effective opportunities to communicate with large audiences. Reformers rely upon these access rights to overcome disparities in speakers' capitalization, communicative and marketing skills, perceptivity, popular acceptance, organizational skills, contmuing commitment, stature, hard work, charisma, luck, and all other factors which traditionally determine a speaker's effectiveness in communicating with his audience. Yet such reliance seems unfounded; indeed, these reforms create significant problems of their own.

All reform proposals attempt to ensure either "adequate" or "equal" access. ${ }^{246}$ Adequate access does not mean that everyone must

242. Barron, supra note 73 , at 1678.

243. A. Meiklejohn, Political Freedom 19 (1960); see also Commission on Freedom of the Press, A Free and Responsible Press 127 (1947)(adopting a similar view). The Supreme Court, however, has struck down some statutes ostensibly designed to enrich the flow of ideas. See, e.g., First Nat'1 Bank v. Belotti, 435 U.S. 765, 790-92 \& n.30 (1977); Buckley v. Valeo, 424 U.S. 1, $48-49$ (1975).

244. For a discussion of the dangers of entrusting government with power to regulate media access, see infra text accoinpanying notes 269-75.

245. See Red Lion Broadcasting Co. v. FCC, 395 U.S. 367, 390 (1975)("It is the right of viewers and listeners, not the right of the broadcasters, which is paramount."); see also CBS, lnc. v. FCC, 453 U.S. 367, 394-95 (1981). But see Columbia Broadcasting Sys. v. Democratic Nat'l Comm., 412 U.S. 94, 126-30 (1973).

246. See generally B. Schmidt, Freedom of the Press vs. Public Access 18-22 (1976) (discussing purposes of access requirements). Some reformers have suggested that vigorous cnforcement of antitrust laws would dismantle monopolistie control of nass communications. See, 
be given a voice or that all perspectives must be granted equal time. It demands only that all viewpoints receive enough access to the public to allow meinbers of society rationally to evaluate each viewpoint's truth and value. ${ }^{247}$ Consequently, where "adequate," "fair," or "reasonable" access has been granted, further access is not required. ${ }^{248}$

For adequate access reform proposals to succeed in correcting the market, however, the public must be able to separate the form and style of a message from its substance. Unless the public can rationally evaluate a communication's content irrespective of its packaging, adequate access provides only the appearance, rather than the reality, of an opportunity to gain a foothold in the marketplace of ideas. Unfortunately, the public's ability to inake these necessary distinctions is, at best, doubtful. ${ }^{249}$

Adequate access reform proposals also require objective criteria for determining whether access has been adequate, criteria that are difficult if not impossible to develop. ${ }^{250}$ To know whether a perspective has received adequate access, a decisionmaker must consider the context, form, and content of the proposed and competing perspectives, as well as the accessibility, socialization, interests, and experiences of the audience. These considerations do not lend themselves readily to standardized judgments; thus, decisionmakers usually must rely on their own subjective judgment.251 This of course opens the door for market failures of a different kind.

e.g., B. OWEN, ECONOMICS AND FREEDOM OF EXPREsSION 184-86 (1975). The Court itself suggested this method of reform in Associated Press v. United States, 326 U.S. 1, 20 (1945)("Surely a command that the government itself shall not impede the free flow of ideas does not afford nongovernmental combinations a refuge if they impose restraints upon that constitutionally guaranteed freedom."). Even if such proposals successfully diversified ownership, however, the prohibitive cost of purchasing or beginning a newspaper or broadcasting station would still limit inedia ownership to the wealthy who, like their predecessors or competitors, are likely to choose only acceptable viewpoints for widespread dissemination. See supra note 195; supra text accompanying notes $186-99$.

247. See Columbia Broadcasting Sys. v. Democratic Nat'l Comm., 412 U.S. 94, 122 (1973); A. Meiklejohn, Polmical Freedom 26 (1960); Emerson, supra note 75, at 818.

248. If the Constitution only requires that each view receive adequate access, the government could permissibly restrain the speech of individuals wanting to further support a position that someone has already expressed in the marketplace. But see Buckley v. Valeo, 424 U.S. 1, 39-51 (1976)(disallowing restraint of speakers even though their perspective may have already been expressed in the marketplace by others); Baker, supra note 1, at $982-83$ \& n.65.

249. See supra text accompanying notes 153-233.

250. Meiklejohn, for exainple, stressed that imder the first ainendment "[w] hat is essential is not that everyone shall speak, but that everything worth saying shall be said." A. MEIKLEJOHN, Political Freedom 26 (1960). Meiklejohn did not specify, however, how to determine what speech is "worth saying."

251. The practical functioning of adequate access proposals reminds one of the capriciousness with which Humpty Dumpty attached meanings to words, see L. CARROLL, THRough THE LOOKING GLASS 94 (spec. ed. 1946), for one does not have any idea whether access is sufficient until the government so determines. See The Handing of Public lssues under the Fairness Doctrine and 
When government officials evaluate adequate access, arbitrary judgments are especially likely.252 A speaker may fail to wm acclaim for his idea in the narketplace either because of madequate access or because the public rejected the merits of his argument. Consequently, before the government can determine whether access has been adequate, first it inust decide implicitly the proper outcome of the marketplace debate. ${ }^{253}$ If the citizenry rejects a perspective which government officials believe is "true" or "best," the officials might well account for the public rejection as due to inadequate market access. On the other hand, if a dissident group, witl which government officials disagree, claims its viewpoint has not succeeded in the marketplace because of inadequate access, government officials are likely to assert that access was adequate and that the dissident viewpoint simply failed to persuade its audience. ${ }^{254}$ If the first amendment requires that unpopular ideas be given an opportunity to defeat established dogma, government

the Public Interests Standards of the Communications Act, 58 F.C.C.2d 691, 707 (1976)(memorandum opinion and order on reconsideration of the fairness report)(Robinson, Comm'r, dissenting). For a description of the fairness doctrine, see infra text accompanying notes 277-80.

Lack of objective standards leads to further difficulties. A debate participant who loses the debate usually believes his perspective failed, not because of its lack of "rightness," but rather because of a malfunctioning inarket. The losing participant may therefore feel justified in using unconventional, disruptive methods to correct these market malfunctions. Such methods, lowever, might well further alienate his prospective audience. See supra text accompanying notes 232-33.

252. If the decision rests with an executive agency, there is always the risk that the doctrine will be used to censor and ultimately restrict the number, scope, and diversity of viewpoints gaining exposure. See Note, Advocacy Advertising: A Question of Fairness and the Reasonable Agcncy, 27 CATH. U.L. Rev. 785, 802 (1978). See generally Note, The Fairmess Doctrine and Access to Reply to Product Commercials, 51 IND. L.J. 756 (1976)(arguing that FCC may not insulate product advertising from fairness obligations); Note, Fairness and Unfairness in Television Product Advertising, 76 MiCH. L. REv. 498 (1978)(examining effect of television product advertising upon viewers and investigating statutory basis of possible FCC intervention). Judicial oversight is available to prevent such censorship, of course, but judicial line-drawing can itself become a facade for governmental censorship. Many first amendment scholars, not surprisingly, have expressed concern over discretion arising from unclear boundaries limiting governmental action. See, e.g., T. EMERSON, FREEDOM OF EXPRESSION, supra note 1, at 10.

253. Historical experience should foster a hearty skepticism about government officials' ability to decide what is "adequate" or "fair" political debate. See Gertz v. Robert Welch, Inc., 418 U.S. 323,346 (1974)(rejecting the ability or appropriatenesss of judges deciding on an ad hoc basis which defamatory publications addressed issues of "general and public imterest" and which did not).

254. Precisely such a governmental attitude may explain the disagreement between O'Brien's position and Justice Harlan's concurrence in United States v. O'Brien, 391 U.S. 367, 388 (1968), discussed supra note 226. The question whether other "adequate" opportumities for presenting O'Brien's views existed was central to Justice Harlan's position. See O'Brien, 391 U.S. at 388-89 (Harlan, J., concurring). $O$ 'Brien argued that the very continuation of the war and draft proved the inadequate access afforded his viewpoint, because his "correct" position would have been successful in a properly functioning narket. Justice Harlan, in turn, presuned adequate access for 
officials should not be allowed to determine the adequacy of access. In short, adequate access proposals almost inevitably further the status quo market bias.

Equal access reform proposals attempt to guarantee either all viewpoimts or all individuals "equal" access to the marketplace of ideas. Reformers who advocate equal access for all viewpoints ${ }^{255}$ beheve that the marketplace can produce a "true" or "best" result, but reject the assumption that the public can separate a message's packaging from its substance. Consequently, by equalizing access for all viewpoints, these reformers seek to neutralize the advantages of "wellpackaged" and frequently offered messages. ${ }^{256}$ In addition to being based on a naive belief in the existence of a "true" or "best" result, 257 this reform approach also poses the danger of presenting the public with more information than it realistically can assimilate. Consequently, rather than guaranteeing all perspectives an opportunity for success, the equal access for viewpoints approach inay only make the public perceive the marketplace as an arena full of nothing but "noise," and thereby decrease the public's willingness to reassess opinions it already holds.

Reformers advocating equal access for all individuals reject all the assumptions underlying the classic inarketplace model: the existence of objective truth, the dominance of rationality, and the ability of the public to distinguish between a message's form and substance. These reformers justify continued support of the marketplace not because the inarket produces the "best" results, but rather because it helps to perpetuate a denocratic systein of government by allowing all people to participate equally in public decisionmaking. ${ }^{258}$ The leveling effect of the equal access for individuals approacl seems, however, inconsistent with the capitalist foundation of our society. 259

Both forms of equal access, that which focuses on individuals as well as that which focuses on viewpoints, suffer additional infirmities. Both define ambiguously what inust be equalized. For example, should a viewpoint indifferently held by a few receive access equal to

O'Brien's perspective did exist and that O'Brien's view merely had insufficient support to change governmental pohcy. See Baker, supra note 1, at 987-88.

255. Meiklejohn's use of the town meeting image to symbolize first amendment goals appears to envision equal access for all viewpoints. See A. MeIKLEJoHn, PolitiCal Freedom 26 (1960).

256. Baker, supra note 1 , at 983.

257. See supra text accompanying notes 121-51.

258. See A. BICKEL, supra note 176, at 62; Baker, supra note 1, at 984 ; Scanlon, Theory of Freedom of Expression, supra note 40, at 214.

259. See Baker, supra note 1 , at 984. 
that of a perspective passionately held by many? ${ }^{260}$ If so, scarce resources may be wasted on trivial ideas, ${ }^{261}$ and the marketplace may reflect inaccurately the strength, and possibly the value, of positions competing for adherents. ${ }^{262}$ Furthermore, guaranteeing such equal access is virtually impossible without an intricate and extensive leveling system of public subsidies and spending restrictions. Even if government officials could design and properly administer such a system, there is no guarantee that an opportunity for equal access would create an opportunity for equal influence. ${ }^{263}$ Regardless of equal access, values in which the public have been indoctrinated or socialized will still prevail, and speakers with stature, influence, and skill will still be more persuasive than those without. ${ }^{264}$ Because equal access still allows variance in the opportunity to influence among differing individuals or viewpoints, equal opportunity to influence can be attaincd only through affirmative action such as by giving the least popular or least able speaker the most access to the marketplace. ${ }^{265}$

260. Cf. Winter, Poverty, Economic Equality, and the Equal Protection Clause, 1972 Sup. CT. REv. 41, 66-77 (the equality created by making certain goods and services free, or by subsidizing their use by some individuals, may lead to grossly inefficient use of scarce resources). In a market where communications are costless or publicly subsidized, individuals or groups with only the nost reinote or incidental interest in an issue's outcoine would have equal input with those for whoin the issue may be a inatter of life and death. One inust question whether such inequality of concern or impact should be irrelevant in allocating communicative opportunities.

The voting-rights cases mandating a one person/one vote requirement suggested that, at least for elections, the Constitution requires governmental indifference to the intensity with which public views are held. See Reynolds v. Sims, 377 U.S. 533, 561 (1964). In an election situation, however, voter intensity is accounted for through the voters' ability and willingness to organize and lobby to influence both election outcomes and the behavior of elected officials. A system of truly equal inarket access, however, would need to guarantee equality of all communication, including lobbying techniques. Consequently, it is unlikely that equal market access systems could register differences in the intensity with which public views are held.

261. Consequently, Meiklejohn insisted that the first amendment protects only speech "worth saying." See supra note 250 (quoting Meiklejohn).

262. See generally Baker, supra note 1 , at 989.

263. The Court noted this concern in Buckley v. Valeo, 424 U.S. 1, 56-57 (1976).

264. Martin Mayer, criticizing the access reform movement in his popular study About Television, has written that

access to media means nothing at all .... Access to audience might have some value. ... But access to audience unust be earned, with talent. There is something bittersweet funny about the sight of all these groups of ardent young lawyers and graduate students and junior executives at foundations, none of whom can write a song anyone would sing or a book anyone would read or a play anyone would act, none of whoin holds a position which gives his thought significance in the lives of others or could gather twenty-five people to hear him speak at a meeting-"deunanding" access to the great audience of an entertainment inediun.

M. Mayer, About Television 388 (1972), quoted in B. SchmidT, supra note 246, at 212.

265. Cf. N. PolSBY, supra note 149, at 135 (discussing Dahl's principle that those with views outside of the "political consensus" may require enormous resources to achieve their goals). 
This exposes a dilemma of marketplace reform. Earlier I argued that market outputs will be biased in favor of dominant values because certain individuals of stature, such as public officials and established imterest group leaders, exercise particular influence when they commumicate. ${ }^{266}$ Correction of this imbalance would demand greater access to the marketplace for those lacking such stature. Such a system would give the greatest access opportunities to those who have no responsibility or accountability to act in the public interest. The development of opimon leaders and individual expertise would be discouraged. ${ }^{267}$ Those individuals perceived by the public as without wisdoin and experience would receive greater access than those believed to have such qualities. Thus, overcommg the marked bias in favor of the statured communicator may create an even more unfortunate result: it inay require us to be confronted most by those who may, in fact, have the least of significance to say. Equal access reform proposals, therefore, either prove insufficient to correct marketplace bias, or create problems equal to those they correct. Additionally, all market reform proposals pose the danger of unacceptable governmental interference with the market.

\section{B. The Dangers of State Intervention.}

Because market reform proposals create the need for government oversight of the mass media, of the allocation of resource subsidies, and of the enforcement of expenditure restrictions, all sucli proposals would generate significant government interference in the marketplace. The success of these reform proposals would require intricate and extensive government regulation. If the primciple of equal access were taken seriously, for example, the likely result would be "a complex of redistributive measures which would make current welfare programs look extremely modest." 268 Thus, such reform measures may put "the hcad of the camel inside the tent and enable administration after administration to toy with [the media] in order to serve its sordid or its benevolent ends." 269

Constitutional limitations on government ensure the public's freedom from arbitrary governmental interferencc in a restricted number of areas, which are predominantly political rather than economic. ${ }^{270}$

\footnotetext{
266. See text accompanying note 234 .

267. See Baker, supra note 1 , at 989.

268. Buchanon, Auronomy and Categories of Expression: A Reply ro Professor Scanlon, $40 \mathrm{U}$. PitT. L. Rev. 551, 557 (1979).

269. Columbia Broadcasting Sys. v. Democratic Nat'l Comm., 412 U.S. 94, 154 (1973)(Douglas, J., concurring).

270. See Manning, Corporate Power and Individual Freedom: Some General Analysis and Particular Reservations, 55 Nw. U.L. REv. 38, 46-53 (1960).
} 
The first amendment has been a primarily negative force preventing government from prohibiting, harassing, or imterfering with speech or other forms of communication. ${ }^{271}$ If courts permit reformers to alter the first amendment's traditional role as a limitation on governmental authority so as to authorize affirmative government action to apportion access rights to the marketplace, the judiciary unwittingly may create a massive censorship system masquerading as marketplace reform.

Indeed, entrusting government with the power to determine media access creates at least three dangers. First, if government requires media to bear the cost of providing access for those opposing a viewpoint that the media have presented, media managers may simply choose not to present controversial issues. ${ }^{272}$ Second, such a process might invite manipulation of the media by the very governmental bureaucrats appointed to ensure access. ${ }^{273}$ Fimally, governmental interference may escalate from access regulation to more dubious types of governmental control. For example, giving government administrators discretion in access decisions risks the use of administrative machinery to force the

271. Professor Thomas Emerson attempted to list the possible ramifications of a system of governmental censorship. He studied the contexts in which governments have invoked censorship and the actions of the responsible agencies. Emerson found that:

(1) There was a consistent tendency to overestimate the need for restriction upon freedom of expression. ...

(2) The forces generated in the administration of limitations on freedom of expression tended to push application of the measures to extremes. . . .

(3) The difficulties in framing definite and precise limitations were not solved. . . .

(4) ... [A]dministration of the limitations resulted in the creation of an enforcement apparatus which embodies practices most obnoxious to a free society. . . .

(5) In practice the restrictions were employed to achieve objectives quite different from the theoretical purposes of the law. . . .

(6) The social gains attributable to the restrictions proved to be mimimal. . . .

(7) On the other hand, the social losses were heavy. The impact of the restrictions was felt not only by those convicted, but by many who were merely prosecuted and by countless others who could not accurately judge the boundaries imposed on freedom or those who were fearful to take the risk.

T. EMERSON, FirST AMENDMENT, supra note 1, at 23-24. Many similar ramifications are likely to result from governmental programs and agencies responsible for marketplace "reform."

272. For example, television networks have rejected requests for the purchase of noncommercial advertisements (advertisements pertaining to issues not directly related to promoting the sale of a product or service) by claiming such advertisements would trigger the FCC's fairness doctrine. See Lee, The Problems of "Reasonable Access" to Broadcasting for Noncommercial Expression: Content Discrimination, Appellate Review, and Separation of Commercial and Noncommercial Expression, 34 U. FLA. L. REV. 348, 352 (1982). For a discussion and evaluation of the fairness doctrine, see infra text accompanying notes 277-314.

273. Even Newton Minow, former Chairman of the FCC, lias acknowledged that groups can and have larassed stations by convimcing scores of individuals who have been criticized on the air to request reply time under the fairness doctrine: "Inevitably, stations react by trymg to avoid such critical programs." Minow, Foreword to S. Simmons, THE FalRness Doctrine AND THE MEDIA at XI (1978). Walter Cronkite of CBS News lias testified that "[i]t is only natural that station inanagement should become timid, and newsmen should sidestep controversial subjects rather than face the annoyance of such harassment." See id. 
media to conform to official positions. Such governmental supervision thus could undermine the media's role as government critic and antagonist. ${ }^{274}$ Therefore, rather than guaranteeing a voice for dissenters, access reforms may well protect government from having to confront a potent media adversary. 275

As the foregoing analysis reveals, market reform proposals either contimue the status quo bias of the marketplace or create new and potentially dangerous problems. A review of two governmental attempts at market revision, 276 the Federal Communications Commission's (FCC) fairness doctrine and the Federal Election Campaign Acts (FECA), demonstrate that experience has confirmed this conclusion.

1. The Fairness Doctrine. Since the 1940's the FCC has placed a "fairness" duty upon radio and television broadcasters. ${ }^{277}$ Broadcasters must provide time, free of charge if necessary, ${ }^{278}$ for the coverage of

274. See Z. Chafee, Government and Mass Communication 476-77 (1947).

275. Nevertheless, corporations that engage in the media business and government may have more areas of common agreeinent than disagreeinent. See infra part IV and text accompanying notes $352-63$.

276. Although courts have upheld legislative attenpts at market reform, the government has never been affirmatively compelled by the courts to protect or enhance anyone's market opportunities. The Supreme Court has refused to create a constitutionally inandated access right, see Columbia Broadcasting Sys. v. Democratic Nat'l Comm., 412 U.S. 94, 127 (1973), or a right to know, see Houchins v. KQED, Inc., 438 U.S. 1,9 (1978). But of. Richmond Newspapers, Inc. v. Virginia, 448 U.S. 555 (1980)(absent some overriding circumstance, the first amendinent guarantees the public and the press the right to attend criminal trials, despite unopposed request of defendant for closed trial).

277. See Barrow, The Equal Opportunities and Fairness Doctrine in Broadcasting: Pillars in the Forum of Democracy, 37 U. CIN. L. REv. 447, 462 (1968). For a concise, layman's explanation of the fairness doctrine, see A. SHAPIRO, MEDIA ACCESS 107-217, 247-54 (1976). For an early history of the doctrine and its original purpose, see Simmons, Fairness Doctrine: The Early History, 29 FED. COM. B.J. 207 (1976). Key faimess doctrine documents include: Broadcast Procedure Manual, 39 Fed. Reg. 32,288, 32,290 (1974); The Handling of Public Issues Under the Fairness Doctrine and the Public Intcrest Standards of the Communications Act, 48 F.C.C.2d 1 (1974) [hereinafter cited as Fairness Report]; Applicability of the Fairness Doctrine in the Handling of Controversial Issues of Public Importance, 29 Fed. Reg. 10,415 (1964); Report on Editorializing by Broadcast Licensees, 13 F.C.C. 1246 (1949) [hereinafter cited as Editorializing]. For an excellent conteinporary analysis of the constitutional questions raised by the doctrime, see Bazelon, FCC Regulation of the Telecommunications Press, 1975 DUkE L.J. 213; see also Schenkkan, Power in the Marketplace of Ideas: The Fairness Doctrine and the First Amendment, 52 TEx. L. REv. 727, 733-40 (1974).

278. Reply tine often has to be provided at the broadcaster's expense, see Cullman Broadcasting Co., 40 F.C.C. 576, 577 (1963); Fairness Report, supra note 277, at 14 n.13; the FCC feared that otherwise the sale of media time would merely convert econounic power into pohitical power. This fear also may explain the Supreme Court's unwillmgness in Columbia Broadcasting Sys. v. Democratic Nat'l Comm., 412 U.S. 94 (1973), to accept the Democratic Party's insistence that CBS was required to sell time for editorial advertisement. Such a ruling would only protect groups who could pay for such advertisements and thus still would most support economically comfortable organizations. Id. at 123. 
controversial issues of public importance 279 and for the presentation of contrasting views concerning such issues. ${ }^{280}$ Furtlermore, individuals personally attacked during a broadcast on these issues are entitled to "reply time" so they can broadcast a response to the attack. 281 The fairness doctrine developed because the clectronic media were allegedly unwilling to open their communication channels to others. ${ }^{282}$ Fairness regulations presume that when a few individuals or groups control a critical mediun, they will stifle competition of ideas and block the einergence of truth. ${ }^{283}$

The fairness doctrine epitomizes the tension within the first ainendment between the broadcasters' right to control program content and the audience's need for access to diverse perspectives. ${ }^{284}$ In Red Lion Broadcasting Co. v. FCC, 285 the Supreine Court upheld the FCC's reply tine requireinent, ${ }^{286}$ and found that rather than violating the broadcasters' first ainendment rights, the fairness doctrime furthered the

279. A holder of a federal broadcast license is required to survey community interests within the receiving area of his licensed broadcast signal. Faimess Report, supra note 277, at 10 \& n.9 (citing Primer on Ascertainment of Community Problems by Broadcast Applicants, 20 F.C.C.2d 880,881 (1969)). A nontrivial portion of broadcast time must be devoted to the treatment of public issues deemed significant within his broadcast area. Fairness Report, supra note 277, at 7, 9. Each broadcaster bears this expense, if commercial sponsorship is unavailable, whether or not the licensee would personally have chosen to forebear sucli coverage. See supra note 278.

280. Each licensee who broadcasts a partisan perspective on any controversial public issue must also provide a fair representation of other views, although not necessarily on the same program and not necessarily in equal proportion to the time, or timing, of the original broadcast. Fairness Report, supra note 277, at 7-8, 10-11. This obligation is not lessened even when other broadcasters in the same market have carried opposing views, id. at 10-11, or when such views already may lave been featured in other sources of news and opinion (such as newspapers and magazines) readily accessible to persons within the same market. See Brandywine Main Line Radio, Inc. v. FCC, 473 F.2d 16, 63-80 (D.C. Cir.)(Bazelon, J., dissenting), affg 27 F.C.C.2d 565 (1972), cert. denied, 412 U.S. 922 (1973).

281. See Amendment of Part 73 of the Rules to Provide Procedures in the Event of a Personal Attack or Where a Station Editorializes as to Political Candidates, 8 F.C.C.2d 721, 723-24 (1967).

282. See M. ERnest, The First FreedoM 176 (1946)(quoting Sen. Burton K. Wheeler)(radio broacasters fail to present all views).

283. See Editorializing, supra note 277, at 1249. For an attack on the premise that the broadcastimg industry is monopolistic, see R. POSNER, ECONOMIC ANALYSis OF LAW § 22.3, at 312-13 (1972).

284. For a discussion of broadcast regulations and the first amendment, see generally $B$. OWEN, supra note 246; B. SCHMWT, supra note 246; Robinson, The FCC and the First Amendment: Observations on Forty Years of Radio and Television Regulation, 52 MiNN. L. REv. 67 (1967).

285. 395 U.S. 367 (1969). During part of a "Christian Crusade" broadcast series aired by the defendant station, the Reverend Billy James Hargis attacked author Fred J. Cook. Hargis, discussing Cook's book, Goldwater-Extremist on the Right, claimed that a newspaper liad fired Cook because Cook had falsely leveled charges against a city official and that Cook had subsequently worked for The Nation, "one of the most scurrilous publications of the left." Red Lion, 395 U.S. at 371 n.2. Cook demanded free reply time and, upon the station's refusal, filed a formal letter of coinplaint with the FCC.

286. The Court contended:

It is the purpose of the First Amendinent to preserve an uninhibited marketplace of ideas in which truth will ultimately prevail, rather than to countenance monopolization of that 
first amendment's goal of informing the public. ${ }^{287}$ The Court attempted, however, to limit the Red Lion opinion to the broadcast media under a "pubhic airwaves" rationale.288 Because the number of available television and radio frequencies cannot accommodate all those wishing to broadcast their message, the government licensing of frequency use was justified to prevent airwave interference from crippling the broadcast system. ${ }^{289}$ On the basis of this practical justification for governmental regulation, the Court upheld the doctrine's regulation of program content. ${ }^{290}$ As a result, government is now fully invoived in and is allegedly responsible for the opening of communication channels to groups otherwise unable to command access. ${ }^{291}$

market, whether it be by the government itself or a private licensee. . . . It is the right of the public to receive suitable access to social, political, esthetic, moral and other ideas and experiences which is crucial here.

Red Lion, 395 U.S. at 390 . In CBS, Inc. v. FCC, 453 U.S. 367, 397 (1981), the Court held constitutional a statute that provided candidates for federal office with "reasonable access" to the broadcasting media. See 47 U.S.C. § 312(a)(7) (1976). Chief Justice Burger, writing for the majority, reiterated the conclusion that "it is the right of the viewers and listeners, not the right of the broadcasters, which is paramount." "Id. at 395 (quoting Red Lion, 395 U.S. at 390)(emphasis omitted).

287. Red Lion, 395 U.S. at 375.

288. Indeed, the Court has subsequently indicated that Red Lion has only such limited applicabihity. See First Nat'l Bank v. Belotti, 435 U.S. 765, 791 n.30 (1978).

289. See Red Lion, 395 U.S. at 389:

There is nothing in the First Amendment which prevents the government from requiring a hicensee to share his frequency with others and to conduct himself as a proxy or fiduciary with obhgations to present those views and voices which are representative of his community and which would otherwise, by necessity, be barred from the airwaves.

290. Id. at 388-90. The logic of Red Lion, however, is fiawed. Although there may be a threshold need for governmental regulation, techniques less imtrusive than the fairness doctrine could solve problems of frequency interference. $C f$. Shelton v. Tucker, 364 U.S. 479, 488 (1960)(insisting that state use least restrictive means when regulating first amendment interests).

291. Many states, responding to similar claims of unfair access distribution, enacted statutes requiring newspapers either to retract defamatory statements they had circulated or to publisis a reply by the defamed imdividual. The Court held these statutes unconstitutional in Miami Herald Publishing Co. v. Tornillo, 418 U.S. 241, 258 (1974). In 1972 Tornillo was a candidate for the Florida House of Representatives. The Miami Herald on two occasions printed editorials critical of his candidacy. In response, Tornillo demanded the paper print verbatin his replies. The Herald refused. Id. at 243-44. Tomillo brought suit under the Florida "right of reply" statute, Fla. Stat. ANN. $\$ 104.38$ (West 1973)(repealed 1975):

[I] $f$ any newspaper in its columns assails the personal character of any candidate for nomination or for election, . . . [or] attacks his official record, . . . such newspaper shall upon request of such candidate immediately publish free of cost any reply he may make thereto im as conspicuous a place and in the same kind of type as the matter that calls for such reply, provided such reply does not take up more space than the matter replied to.

Tornillo argued that restriction of entry imto the media marketplace had given newspapers the same control over communication that limited frequencies gave to broadcasters. He stressed that the economic environment had caused American newspapers to become big busimess, placing "im a few hands the power to inforn the American people and shape public opinion." Tornillo, 418 U.S. at 250. Consequently, the reply statute was a rough counterpart to the FCC's fairness doc- 
The fairness doctrine raises innumerable questions. Who determines whether a broadcaster is being fair? What controversial issues of

trine reply provision and should be held equally constitutional. The Court rejected Tornillo's argument. Id. at 254. The Court feared that the economic ramifications of a right to free reply space would "chill" the press. Id. at 257-58. The Justices also were concerned that the Florida statute would intrude upon the function of editors. Id at 258.

The apparent contradiction between Tornillo and Red Lion must be considered. If scarcity of resources is the basis for regulation, any distimction between the cases seems unjustified, both in the context of the cases themselves, see F. FRIENDLY, THE GOOD GUYS, THE BAD GUYS, AND THE FIRST AMENDMENT 5-7 (1975)(Miami Herald much less subject to meaningful competition than Red Lion broadcast licensee), and in the context of their corresponding media forms today. As the number of newspapers decreases and the cost of rnnning successful ones increases, many communities lave fewer papers than broadcast stations. See "Freedom and the First Amendment", Remarks by Willian S. Paley, Chairman, CBS, Inc., delivered at The Family of Man Awards Dinner held by the Council of Churches of the City of New York 4-5 (Nov. 16, 1982)(nearly 81/2 broadcasting stations and cable systems for each daily newspaper in 1981)(copy on file with author) [hereinafter cited as Paley Speech]. But even if we accept the distinction and assume persons can enter the print media more easily than the broadcast media, the question remains why the purported openness of the newspaper market cannot be considered an important factor in assessing the significance of concentration in the broadcast inedia. Conceivably, an alternative conclusion to draw from this situation is that legislative action is not required in any media branch, i.e. the print media, as long as people can gain access somewhere within the mass media as a whole.

In considering why the Court has allowed broadcasters to be closely regulatcd under the auspices of the FCC while it has protected the print media, at least three factors merit discussion. First, the print media in the United States has a history and tradition of crusading against, and being protected from, governmental interference. But cf. Act of July 14, 1798, ch. 74, 1 Stat. 596 (Sedition Act, expired 1801); Espionage Act, ch. 30, § 3, 40 Stat. 217, 219 (1917)(repealed 1948). Because electromic media are relatively young and have always been subject to some governmental control, there is no tradition of freedom to overcome and there is thus less appearance of illegitimate governmental action. If the first amendment's concern is only to maintain the appear. ance of a government prohibited from illegitimate interference with the media, the difference between Red Lion and Tornillo makes sense.

Second, unlike the electromic media's licensing system, the print media lias an unlimited number of frequencies, i.e., printing presses; accordingly, there is no threshold need for government rationing. The argument that the prohibitive cost of starting a newspaper liznits access in a way analogous to the scarcity of broadcast frequencies, and therefore justifies state mvolvement, has not been successful. Our existing capitalist system of value distribution therefore has been preserved: although the press may be an economically scarce resource, it remains generally available to the wealthy. The well to do, however, are not assured access when dealing with a scientifically scarce resource, the electronic media, which by necessity is distributed by a nonmarket process. Thus, because the science of the broadcast media lias practical imperatives, market reform in this latter setting is not as clearly inconsistent with capitalist principles as is the case with the print media.

The first two suggested grounds for distinguishing the press from the electronic inedia both address the appearance of governmental involvement. Yet the marketplace model assumption of open access makes no distmction between limitations from governmental and nongovernmental sources; it can tolerate limits from neither. If market reformers imtend to break down elitist control of communications, it is indefensible to distinguish the press from the electronic media. $C$. Bollinger, Freedom of the Press and Public Access: Toward a Theory of Partial Regulation of the Mass Media, $75 \mathrm{MrCH}$. L. Rev. 1, 2 (1976)("the Court should now acknowledge that for first amendment purposes broadcasting is not fundamentally different from the print media").

The third potential distinction between Red Lion and Tornillo is of a somewhat different order. Certaim types of imdividual behavior, mcluding some kinds of speech, are capable of creat- 
public importance must a broadcaster include in his programming? What is a reasonable balance between contrasting views on issues? How should groups be guaranteed an opportunity to speak their views over the airwaves? Does government intervention to balance public issue programming improperly inhibit broadcasters from determining the content of their programming? Does government intervention itself create the market distortion it is supposed to prevent?

The requirement that issues be both controversial and of public importance before the fairness doctrine can be mvoked is an understandable attempt to ensure that scarce and expensive resources are not wasted with trivialities or matters of only marginal public concern. ${ }^{292}$ This requirement, however, unavoidably results in government officials or judges determining the agenda of issues worthy of public consideration. The scenario of governmental officers debating what the public does and does not have a right to know is constitutionally questionable at best. The fairness doctrine inevitably requires repeated ad hoc evaluations of whether coverage of a specific "issue" would be wasteful, a mere whetting of public curiosity, or would convey inforination about which the public has a justifiable interest. Such determinations by government officials conflict with the very core of first amendment marketplace theory. ${ }^{293}$

To minimize the potential danger and arbitrariness of purely subjective evaluations of an issue's importance, the FCC has added a number of "objective" criteria for determining which issues are both important and controversial.294 "Public importance" is determined, at least in part, by the degree of inedia coverage and the degree of attention an issue receives from government officials and other community

ing highly impassioned community responses. When dealing with such areas, federal courts have been inore comfortable with decisions made by federal agencies such as the FCC, representing national communities, than with those made by state institutions representing secluded local cominunities such as in Tornillo. Cf. Ingber, supra note 124, at $866 \&$ n.31 (noting that federal statutes are more likely to survive "lack of notice" challenges than are state laws). But see Miller v. California, 413 U.S. 15, 24 (1973)(local community standards to be applied in defining obscenity). Judicial acceptance of federal but not state reform proposals, therefore, may protect a national doninance in the creation of orthodoxy in the face of challenges from locally dominant groups whose views do not conform to those of national elites. This point, as well as that suggesting that prevention of the perception of governmental bias of the market is the true function of the first amendment, will be developed more fully infra in part IV.

292. This concern with not wasting scarce inedia resources is precisely the ground upon which the Court concluded, in Columbia Broadcasting Sys. v. Democratic Nat'l Comm., 412 U.S. 94, 125 (1973), that an unlimited right of access would not best serve the public interest.

293. See Gertz v. Robert Welch, Inc., 418 U.S. 323, 346 (1974).

294. Fairness Report, supra note 277 , at 13-14. 
leaders.295 "Controversiality" demands a consideration of these same factors, as well as whether an issue has been debated vigorously withim a given community. ${ }^{296}$ In addition, the fairness rules require only that "inajor viewpoints and shades of opinion"297 be aired; they do not require that all opinions on the subject be presented.298 Consequently, the views of sinall minorities may well not receive any assistance from the doctrine.

Obviously there is a tension between a first amendinent designed to protect speech that the community wishes to silence 299 and a fairness doctrine contingent upon debate among substantial elements of the community. Because ideas nust already be popular to some degree to merit the doctrine's application, ${ }^{300}$ the doctrine gives government assistance to viewpoints precisely when government involvement is least important. In fact, the doctrine grants further access to views of significant community leaders that already liave been actively debated within the marketplace. This inerely compounds the market advantage lield by community leaders over those who find the inedia intractable and community leaders insensitive or unsympathetic.

In addition to these theoretical difficulties, the regulatory apparatus created to enforce the fairness doctrine has potential for abuse. During the Nixon presidency, executive brancl officials attempted to use the FCC to reduce nredia criticism of the administration ${ }^{301}$ and

295. See id. at 11-12. Polls and contacts with previously identified community leaders are required for the determination of "public importance." Because such a process of information gathering is likely to reflect rather than challenge the concerns of existing leadership, it contains an inherent bias in favor of the status quo.

296. $I d$. at 12.

297. Id. at 15 (emphasis omitted).

298. See generally Primer on Ascertainment of Community Problents by Broadcast Applicants, 27 F.C.C.2d 650 (1971).

299. Even the FCC, at an earlier time, required that licensees ignore the "possible unpopularity" of a viewpoint. Editorializing, supra note 277 , at 1250 , para. 7. This position is clearly not in accord with the standards articulated in the 1974 Fairness Report. See Fairness Report, supra note 277 , at $11-12$.

300. If the rest of the community scoffs at a lone dissenter's ideas, there is no debate and therefore no fairness requirement. See Fairness Report, supra note 277, at 11-12. If rejection of the idea is due to insufficient access for a full articulation of the viewpoint, or to unappealing nonmedia packaging, then the fairness doctrine will deny an idea access because it did not have sufficient initial access to develop beyond an embryomic stage. These circularity problems should not be discounted.

301. In 1970 Clrarles Colson, the Special Counsel to the President, wrote a memo to White House Chief of Staff H.R. Haldeman containing the following:

I will pursue with Dean Burch [the FCC Chairman appointed by President Nixon] the possibility for an interpretive ruling by the FCC on the role of the President when he uses TV, as soon as we lave a inajority. I think this point could be very favorably 
punish those members of the media viewed as the worst offenders. ${ }^{302}$ There is no reason to believe that this abuse of process is limited to the Nixon/Watergate era. Professor Fred W. Friendly has uncovered evidence that in 1963 the Democratic National Committee (DNC) used the evolving reply right for partisan political purposes. ${ }^{303}$ Democrats discovered that the fairness doctrine could be used to inhibit broadcasts favoring conservative positions associated with Senator Barry Goldwater. According to Friendly, the DNC set up and funded a "nonpartisan" committee to monitor such broadcasts, and, by demanding free reply time, the DNC sought to harass stations that carried riglit-wing programs. The DNC tlus hoped not merely to gain balanced coverage but to inhibit anti-Democratic broadcasts. ${ }^{304}$ One cannot help but wonder if the doctrine's potential for governmental abuse of this sort is worth whatever inarginal advantage disadvantaged groups obtain through governmental interjection. ${ }^{305}$

The impact of the fairness doctrine on the marketplace of ideas may, in fact, be counterproductive. The fairness requirement may encourage bland, noncontroversial programming as a result of both eco-

clarified and it would, of course, have an inhibiting impact on the networks. . . . I think we can dampen their ardor for putting on "loyal opposition" type programs.

Washington Post, Dec. 3, 1973, § A, at 24, col. 5 (memorandum reprinted).

In addition, the New York Times contended in May 1974 that the Nixon White House had actively considered the imposition of reprisals against the Washington Post for its Watergate coverage by not renewing broadcast licenses held by the Post's parent company. N.Y. Times, May 16, 1974, at 1, col. 3.

302. The New York Times published a memo written by White House Assistant Jeb Stuart Magruder to Chief of Staff H.R. Haldeman suggesting that "the FCC begin "an official monitoring system' to prove bias on the part of the networks." N.Y. Times, Nov. 1, 1973, at 34, col. 3.

303. See Friendly, What's Fair on the Air?, N.Y. Times, Mar. 30, 1975, § 6 (magazine), at 12.

304. An excerpt from a report by Wayne Phillips, the executive at the DNC who set up the monitoring effort, indicates the DNC's intent: " "E]ven more important than the free radio time, however, was the effectiveness of this operation in inhibiting the political activity of these rightwing broadcasts." "Id. at 37, col. 1 . Although a DNC atteinpt simply to give airtime to Deinocratic viewpoints would be quite consistent with the premises of the fairness doctrine, another DNC memorandun quoted by Friendly shows that this was not the DNC's primary motive:

The right-wingers operate on a strictly cash basis and it is for this reason that they are carried by so many small stations. Were our efforts to be continued on a year-round basis, we would find that many of these stations would consider the broadcast of these programs bothersone and burdensome (especially if they are ultimately required to give us free time) and would start dropping the programs from their broadcast schedule.

N.Y. Times, Apr. 27, 1975, §6, pt. 1 (Magazine), at 70, col. 4 ("letters" section). This abuse of the fairness doctrine obviously is similar to another of Professor Emerson's conclusions about censorship systems. See supra note 271 (quoting Emerson).

305. These concerns with potential government abuse echo a number of the dangers Professor Emerson identified in systems of censorship. See supra note 271 (quoting Enerson). He concluded that governments often overestimate the need for restriction, have difficulties in framing definite and precise limitations, and utilize restrictions which only minimally contribute to articulated goals. See id. 
nomic cost and institutional insecurity. ${ }^{306}$ Broadcasters, fearing the cost of balanced presentations or the expense of defending against a complaint for unbalanced programming, may avoid controversial issues altogether. In 1979, for example, over 5000 such coinplaints were filed with the FCC. ${ }^{307}$ Only a handful were successful, ${ }^{308}$ but those successes demonstrate a governmental power to control aspects of the media. The mere existence of this power chills some broadcasters and causes others to censor themselves. ${ }^{309}$ Given the indefiniteness of the standards to which the FCC will hold broadcasters and the significant expense and disruption of defending against a coinplaimt, ${ }^{310}$ broadcaster conservatism should take no one by surprise. ${ }^{311}$ Rather than encouraging diversity in public debate, a "fair" market may instead be dominated by a dull "centrisin." 312

The fairness doctrine thus has not assured marketplace access to those individuals, groups, and viewpoints least able to gain public ex-

306. Many critics of the fairness doctrine argue that it discourages journalists from engaging in discourse on important social issues. See Paley Speech, supra note 291, at 7; see also Kalven, Broadcasting, Public Policy and the First Amendment, 10 J.L. \& ECON. 15, 19-23 (1967); Robinson, supra note 284, at 136-40; cf. Lange, The Role of the Access Doctrine in the Regulation of the Mass Media: A Critical Review and Assessment, 52 N.C.L. Rev. 1, 70-71 (1973)(discussing right of reply).

The possibility that journalists will shirk their responsibility to address controversial issues is accentuated because the FCC has more vigorously enforced the requirement that broadcasters present the issues that they choose to air in a balanced fashion than it has enforced the requirement that licensees devote a reasonable time to issues of public importance. Simmons, The Problem of "Issue" in the Administration of the Fairness Doctrine, 65 CALIF. L. REv. 546, 548 (1977). Thus, broadcasters can minimize the doctrine's impact on their programming by mimimizing the coverage of controversial issues.

307. Paley Speech, supra note 291, at 3.

308. $I d$.

309. Id.

310. For example, Sherwyn H. Heckt, 40 F.C.C.2d 1150 (1973), a fairness doctrine case resolved in favor of the licensee, consumed 480 hours of station personnel time and legal expenses of about \$20,000. First Amendment Clarification Act of 1977: Hearings on S.22 Before the Subconm. on Communications of the Senate Comm. on Commerce, Science, \& Transportation, 95th Cong., 2d Sess. 62 (1978)(statement of Henry Geller); see H. Geller, The Falrness Doctrune IN BROADCasting: Problems and Suggested Courses of Action 40-43, 134 (Rand Corp. No. R-1412FF 1973).

311. See Interview with Bill Monroe by Steven J. Simmons (Sept. 12, 1975), quoted in S. SiMMONS, supra note 273, at 217 (describing broadcaster conservatism in face of FCC complaints).

The broadcasters' responses to the fairness doctrine are reminiscent of Professor Emerson's conclusion that the impact of censorship is felt not only by those convicted, but also by many merely prosecuted, and by countless others who cannot accurately judge the boundaries imposed on freedom or who are fearful to take the risk of prosecution. See T. EMERSON, First AMENDMENT, supra note 1, at 23-24 (quoted supra note 271).

312. This tendency toward conservatism is eloquently criticized in Lange, supra note 306 , at 77-89. Broadcaster conservatism is further encouraged by the Commission's statement of duties under the fairness doctrine. Fairness Report, supra note 277, at 15 ("the broadcaster . . . is not expected to present the views of all political parties no matter how sunall or insignificant"). 
posure. Indeed it has enhanced access differentials between traditional positions and unconventional views. It also has been employed to achieve objectives inconsistent with the doctrine's theoretical purpose. $^{313}$ Cogent arguments have been made that imstead of correcting marketplace flaws and biases, the fairness doctrine has compounded them. ${ }^{314}$

2. Federal Election Campaign Acts. The Federal Election Cainpaign Acts (FECA) ${ }^{315}$ suffer from similar infirmities. In 1976, the Supreme Court confronted a number of constitutional challenges to the key provisions of FECA in Buckley v. Valeo.316 With FECA, Congress attempted to reforin the inarketplace by limiting the influence of advantaged individuals or groups during federal election campaigns. FECA appeared to foster "equal" access for both viewpoints and individuals whereas the fairness doctrine assures "adequate" presentation for varied viewpoimts.

FECA combined coinplex contribution and expenditure limitations, ${ }^{317}$ reporting and disclosure requirements, ${ }^{318}$ and public subsidies

313. The Supreme Court's recent approval of federal legislation that provides federal candidates with "reasonable access" to the broadcasting media, see CBS, Inc. v. FCC, 453 U.S. 367,397 (1981), may itself lead to abuse. Justice Stevens, in dissent, expressed the fear that the FCC's approach to the candidate access claims "creates an impermissible risk that the Commission's evaluation of a given refusal [to grant a candidate access time] by a licensee will be biased-or will appear to be biased-by the character of the office lield by the candidate making the request." Id. at 419 .

314. "I have no doubt," remarked William S. Paley, the Chairman of CBS, "that broadcasting would produce a greater abundance of diverse and informative programming" if the fairness doctrime was eliminated along with the provisions for equal time and the criteria for access. Paley Speech, supra note 291, at 7 . In fact, there has been some movement, though unsuccessful, to repeal the fairness doctrine and other equal opportunity requirements. See, e.g., Repeal of "Equal Time" Requirements: Hearing on H.R. 6013 Before the Subcomm on Communication of the House Comm. on Interstate \& Foreign Commerce, 96th Cong., 2d Sess. 5 passim (1980).

315. Regulation of federal elections was accomplished through numerous statutes and amendments. See Presidential Election Campaign Fund Act, Pub. L. No. 92-178, 85 Stat. 562 (1971); Federal Election Campaign Act of 1971, Pub. L. No. 92-225, 86 Stat. 3 (both statutes amended by Federal Campaign Act Amendments of 1974, Pub. L. No. 93-443, 88 Stat. 1263, and Federal Election Campaign Act Amendments of 1976, Pub. L. No. 94-283, 90 Stat. 475, and Federal Election Campaign Act Amendments of 1979, Pub. L. No. 96-187, 93 Stat. 1339)(both statutes codified as ameuded in scattered sections of 2 U.S.C., 26 U.S.C., and other scattered sections). Unless otherwise noted, this statutory scleeme will be discussed as the Court confronted it in Buckley v. Valeo, 424 U.S. 1 (1975), and will be referred to under the simgle rubric of "FECA."

316. 424 U.S. 1 (1976).

317. See FECA Amendments of 1974, \& 101, 88 Stat. 1263, 1263 (substitute provisions added by FECA Amendenents of 1976, $\S 112(2), 90$ Stat. 475, 486 (codified as amended at 2 U.S.C. $\S 441$ (19 (1982))). The contribution and expenditure limits were, together, an attempt to prevent a financially well endowed candidate from defeating another candidate by merely outspending him in the marketplace. The Act imposed a $\$ 1000$ limitation on an individual's contributions to a single candidate, a $\$ 5000$ limitation on contributions by a political committee to a single candi- 
of election campaigns ${ }^{319}$ to foster the goal of equality. The Buckley Court found only a portion of this legislative package consistent with the first amendment.

In a per curiam decision, the Court upheld FECA's contribution restrictions as a limitation upon "the actuality and appearance of corruption resultimg from large . . . financial contributions"; 320 but the Court held expenditure restrictions unconstitutional because they reduced the quantity of expression in the marketplace and, thus, restricted "the number of issues discussed, the depth of their exploration, and the size of the audience reaclied." 321

Without expenditure limitations, however, FECA can accomplish little market reform. Wealtly candidates and their financially able supporters can still imundate the marketplace with their message, and thereby block out fair perception of the positions of their less wellheeled opponents. ${ }^{322}$ In fact, the Buckley Court explicitly rejected as illegitimate any congressional goal to equalize the relative ability of individuals and groups to influence the outcome of elections. ${ }^{323}$

The Court, however, did uphold the FECA provisions that author-

date, and a $\$ 25,000$ limitation on total contributions by an individual during any calendar year. FECA Amendments of 1974, § 101(a), 88 Stat. 1263, 1263. The Act also limited expenditures made by individuals and groups "relative to a clearly identified candidate" to $\$ 1000, F E C A$ Amendments of 1974, $\S 101(\mathrm{a}), 88$ Stat. 1263, 1265, restricted candidates in the use of their own personal funds, and placed ceilings on total campaign costs, FECA Amendments of 1974, $\$$ 101(a), 101(b), 88 Stat. 1263, 1264, 1266.

318. See FECA Amendments of 1974, $\S \S 201-208,88$ Stat. 1263, 1272-79 (codified as amended at 2 U.S.C. $\S \S 431-434$ (1982)).

319. See Presidential Election Campaign Fund Act, Pub. L. No. 92-178, 85 Stat. 562 (1971), amended by FECA Amendments of 1974, $\$ \S 403-408,88$ Stat. 1263, 1291-97 (current provisions codified as amended at 26 U.S.C. $\$ \$ 9001-9008$ (1976 \& Supp. V 1981) and other scattered sections).

320. Buckley v. Valeo, 424 U.S. 1, 26 (1975). In addition, the Court upheld reporting and disclosure provisions as a means to provide the electorate with information as to where political campaign money originates in order to aid the voter in evaluating those who seek federal office. Id. at 66-67. The Court also deemed the requirements justified as a means of deterring corruption and the appearance of corruption and as an essential means of gathering the data necessary to detect violations of the Act's contribution limitations. Id. at 67. The provisions required campaign organizations periodically to report to the Federal Election Commission all individual contributions of over $\$ 100$ and all political committee contributions regardless of their size. FECA of $1971, \S 3.04,86$ Stat. 3, 15 (codified as amended at 2 U.S.C. $\$ 434$ (1982))(the $\$ 100$ requirement since lias been raised to $\$ 200$, FECA Amendments of 1979, \$104, 93 Stat. 1339, 1351).

321. Buckley, 424 U.S. at 19.

322. Because the Court upheld individual and group campaign contribution limitations, see Buckley, 424 U.S. at 24-38, individuals or groups desiring to sponsor advertising that supported a candidate's election often have funneled their money through organizations other than the candidate's official campaign committee or have purchased the time or space for such advertising themselves.

323. See id. at 48-49 (quoting New York Times Co. v. Sullivan, 376 U.S. 254, 269 (1964) and Roth v. United States, 354 U.S. 476, 484 (1957)): 
ized public funding of presidential election campaigns. ${ }^{324}$ It viewed leveling campaign expenditures among presidential candidates not as a mechanism to abridge, restrict, or censor speech, but rather as an attempt to use public money to "enlarge public discussion and participation in the electoral process, goals vital to a self-governing people." ${ }^{325}$ The subsidy provisions do not, lowever, treat all candidates as equals. Major political parties-defined as parties that had secured over twenty-five percent of the vote in the preceding presidential electionqualify for up to two million dollars of fundimg for expenses incurred in connection with their nominating canupaigns and for subsidies of up to twenty million dollars for their candidate's presidential campaigns. 326 Mimor parties-defined as those that liad secured between five percent and twenty-five percent of the vote in the preceding presidential election ${ }^{327}$-qualify for convention reimbursements and cainpaign subsidies proportional to their share of the vote in the preceding election, with the possibility of additional post-election payments if they mcrease their share of the vote. ${ }^{328}$ Other political parties or candidates qualify for post-election support only if they obtain over five percent of the vote in the current election. ${ }^{329}$ The Buckley Court brushed aside as "speculative" the insistence by representatives of nonestablished groups that such a subsidy system would harm their interests. ${ }^{330}$ The Court deemed such harm imsufficient to overcome Congress's purpose to prevent the use of public money to "foster frivolous candidates, create a system of splintered parties, and encourage unrestrained factionahsm."'331

[T] he concept that government may restrict the speech of some elements of our society in order to enhance the relative voice of others is wholly foreign to the First Amendment, which was designed "to secure "the widest possible dissemination of information from diverse and antagonistic sources," " and " "to assure unfettered interchange of ideas for the bringing about of political and social changes desired by the people."

324. See Buckley, 424 U.S. at 85-109.

325. Id. at $92-93$.

326. Presidential Election Campaign Fund Act, $\S \S 9002-9008,85$ Stat. 562, 563-69, amended by FECA Amendments of 1974, $\$ \S 404-406,88$ Stat. 1263, $1291-96$ (current provisions codified as amended at 26 U.S.C. $\$ \S 9002-9008$ and other scattered sections)(apart from the $\$ 2,000,000$ provided for in $\S 9008$, which has since been raised to $\$ 3,000,000$, see FECA Amendments of 1979 , $\S 202$, 93 Stat. 1339, 1368 (codified at 26 U.S.C. $\S 9008(b)$ (1) (Supp. V 1981)), these provisions adjust the amounts disbursed in any given year to account for inflation).

327. See Presidential Election Campaign Fund Act, $\S 9002(7), 85$ Stat. 562, 563 (codified at 26 U.S.C. $\S 9002(7)(1976)$ ).

328. Presidential Election Campaign Fund Act, \& 9004(a)(2)(A), 85 Stat. 562, 565, amended by FECA Amendments of 1974, $8 \S 404(\mathrm{~b})(1), 406(\mathrm{a}), 88$ Stat. 1263, 1291, 1294 (codified as amended at 26 U.S.C. $\$ \S 9004(a)(2)(A), 9008(b)(2)$ (1976)).

329. Presidential Election Campaign Fund Act, $\$ 9004(\mathrm{a})(3)$ ), 85 Stat. 562, 566 (codified as amended at 26 U.S.C. $\$ 9004(\mathrm{a})(3)(1976))$.

330. Buckley, 424 U.S. at 101.

331. Id. 
The public campaign finance measures do hittle or nothing to give powerless groups or individuals enhanced access to effective means of pohtical expression. No money is made available for parties receiving less than five percent of the vote in both the current and previous election. ${ }^{332}$ Funds for primaries are available only for parties that hold a convention or for candidates that participate in primaries. ${ }^{333}$ Such regulations create significant disadvantages to minority parties and independent candidates, ${ }^{334}$ who are most likely to need help publicizing their views. In fact, the subsidy system may decrease the chance that a minority party will receive five percent of the vote, by increasing the funds available to its already richer rivals. ${ }^{335}$ Public financing under FECA appears to have "enshrined the Republican and Democratic parties in a permanently preferred position." 336

332. A party may receive funds subsequent to an election in which it receivcd over five percent of the vote, even if it received less than five percent in the previous election. See Presidential Election Campaign Fund Act, $\S 9004(a)(3), 85$ Stat. 562, 566 (codified as amended at 26 U.S.C. $\S 9004(a)(3)$ (1976)). The possibility of a minority party or independent candidate receiving pubhic funds after the election does not assuage, however, the disadvantage to holders of minority views. Candidates need funds before the election. Candidates who could sccure five percent of the vote if given the funds prior to the election very well may not reach the five percent threshold without the additional resources those funds provide. The suggestion by some that such candidates could secure loans before the election, see Buckley, 424 U.S. at 102, may be overly optimistic. There is, in any event, something troubling about committing the fate of a candidate to the opinion of a "loan officer"; indeed, the financial community may well be hostile to the candidate's views.

John Anderson's storied campaign for the presidency in 1980 aceumulated an estimatcd $\$ 5,000,000$ debt in anticipation of receiving post-election funds. See N.Y. Times, Nov. 5, 1980, at A21, col. 1 . The difficulties in candidates and creditors relying on such funds is reflected in Mrs. Anderson's response to a question as to what she and her husband would do if the funds were not received: "we will both get jobs." Id. at A21, col. 2. Luckily for Mrs. Anderson, Mr. Anderson tallied over $5 \%$ of the electorate.

333. See FECA Amendments of 1974, §§ 406(a), 408(c), 88 Stat. 1263, 1299 (codifled as amended at 26 U.S.C. $\$ \S 9008,9033(1976))$.

334. Chief Justice Burger recognized in his Buckley opinion these disadvantages to minority parties and independent candidates. Buckley, 424 U.S. at 251 (Burger, C.J., concurring in part and dissenting in part).

335. Publicly financed elections in this context may strengthen the stronger rather than aid the overwhelmed.

336. Id. at 293 (Relmquist, J., concurring in part and dissenting in part). One critic has aptly depicted the public campaign finance measures as "public subsidies for cstablished parties." Buclianon, supra note 268, at 556.

This difficulty may be accentuated now that all candidates, regardless of political persuasion, are granted reasonable access to television and radio. FECA of 1971, § 103(a)(2)(A), 86 Stat. 3, 4 (adding 47 U.S.C. §312(a)(7) (1976)("The [FCC] may revoke any station license . . . for willful or repeated failure to allow reasonable access to or to permit purchase of reasonable amounts of time . . by a legally qualified candidate for Federal elective office on behalf of his candidacy.")); cf. CBS, Inc. v. FCC, 453 U.S. 367, 394-97 (1981)(upholding 47 U.S.C. \& 312(a)(7) as constitutional). The federal legislation creating this right appears on its face to be neutral to all views, but federal candidates having sufficient funds actually will receive significantly greater access than will those that are poorly funded, because a broadcaster inay continue to refuse all requests for 
Both Congress and the Court understandably were concerned with a market reform that might either make speech costless or so subsidize the speech of all groups that the outcome would be a cacophony of trivia, irrelevancies, and repetitions creating a dysfunctional level of noise and wasted resources. The Buckley Court recognized the need to distribute public largesse discriminately so as to avoid "artificial incentives to 'splintered parties and unrestramed factionalism." "337 But this concern is difficult to reconcile with the first amendment's "profound national commitment to the principle that debate on public issues should be uninhibited, robust and wide-open." 338 Minor parties add variety and complexity to public debate, and often force major parties to address candidly issues they might otherwise be teinpted to avoid. ${ }^{339}$ But even if this were not the case, narketplace theory proscribes government hostility to either new associations ${ }^{340}$ or variety in public debate. ${ }^{341}$ Both the fairness doctrime and FECA, upon analysis, support only those perspectives and viewpoimts already well represented in the marketplace.

\section{Future Reform Possibilities.}

Reform attempts to minimize the marketplace of ideas' status quo bias have been of hittle aid to those with truly deviant ideas. At best, these reforms only slightly widen the market's mainstream views, but

free access, see CBS, Inc., 453 U.S. at 382 n.8. This disparity greatly skews the marketplace in favor of only certain views because it is unlikely that well financed candidates represent the entire political spectrum. Further, because the legislation is directed toward candidates, groups that lack a candidate representing their viewpoint but who wish to speak against a candidate or his views lave no access protection. The public funding of major parties, therefore, magnifies the already existing marketplace skew in favor of dominant groups and orthodox viewpoints.

337. Buckley, 424 U.S. at 96.

338. New York Times Co. v. Sullivan, 376 U.S. 254, 270 (1964).

339. See Illinois State Bd. of Elections v. Socialist Workers Party, 440 U.S. 173, 185-86 (1979).

340. In 1960 the Supreme Court invalidated an ordinance which prohibited distribution of any landbill not bearing the name and address of the person who prepared, distributed or sponsored it. Talley v. California, 362 U.S. 60 (1960). The Court found that the potential chilling of the freedoin of speech and association caused by requiring an individual to identify himself as a supporter of what might be an unpopular view or organization outweighed the state's interest in using this means to identify those responsible for fraud, false advertisement, or hbel. Id. at 64-65. In Buckley, 424 U.S. at 60-84, however, the Court upheld reporting and disclosure requirements that are just as likely to have such chilling effects. Thus, this inarket reforun measure may decrease the public exposure to and perception of dissident positions.

341. Although the major political parties do produce some variety in public debate, history has shown that for such parties to be successful they need to be amorphous, heterogeneous, and heterodox. See Brown, Book Review, 62 Colum. L. Rev. 386, 391 (1962). In order to retain and enlarge their electoral support, the major parties lave assumed a nondivisive "centrism" very similar to that discussed in the context of the fairness doctrine. See supra notes 306-12 and accompanying text. It is therefore not surprising that the basic positions of the major parties have more in common with each other than in confilict. 
their dependence upon government to regulate and perfect the market raises grave issues of government control of communication in a democratic society and is highly dangerous. ${ }^{342}$ The dangers of government involvement and potential abuse seem so great that a laissez-faire system appears preferable to soine despite all of its limitations. ${ }^{343}$

Representatives of the media ${ }^{344}$ and a nuinber of scholars ${ }^{345}$ have insisted that the technology of cable television systems renders obsolete the scarcity of frequencies rationale for the fairness doctrine. These critics propose limiting government regulation to a requirement that cable systems dedicate one channel as a noncommercial public access channel available without charge at all times on a pure first-come, firstserved basis. ${ }^{346}$

If a speaker desires a large, diverse audience, however, he will find special public access channels meffective as forums in which to present competing views on controversial issues. There is something "bittersweet funny" 347 about seeing lomespun attempts on public access channels competing with the professionally packaged presentations found on the commercial channels. The cost of advertising a message to be aired on a public access station in hope of gaining audience attention would often exceed the production costs of the message; ${ }^{348}$ consequently, the audience for a public access channel usually consists of those who personally know the speaker, and thus already are informed of and committed to his views, and those who have tuned in because of random curiosity or a desire to be titillated by the possibly more than

342. See supra notes $268-76,305-12,324-41$ and accompanying text.

343. Emerson, for example, a long-time advocate and defender of the expressive rights of dissidents, concluded that "[t]he system of freedom of expression is by definition a laissez-faire system and must tolerate differences in the economic capacity of the various participants. . . . [A]ny atteinpt to eliminate all differeuces based on economic factors would imvolve governmental regulation and governmeutal domination on a scale that would destroy the system." Emerson, supra note 75, at 823; see Columbia Broadcasting Sys. v. Democratic Nat'l Comm., 412 U.S. 94, 125 (1973)(the risks of a laissez-faire system of free speech are "calculated risks" taken in order to preserve "higher values").

344. See, e.g., Paley Speech, supra note 291, at 4-5.

345. See generally Simmons, The Fairness Doctrine and Cable T.V., 11 HARV. J. ON LEGIS. 629 (1974).

346. See Bollinger, supra note 291 , at 39. On February 12, 1972, the FCC issued rules requiring every cable system within the top 100 inarkets to provide such a public access station. Cable Television Report \& Order, 36 F.C.C.2d 143, 190 (1972).

347. M. MAYER, supra note 264, at 388 (finding similar humor in the character of the persons demanding access time)(quoted supra note 264 ).

348. Cf. Price \& Morris, Public Aecess Channels: The New York City Experience, in Sloan Commission on Cable Communications, ON The Cable app. 229, 230 (1971)("Unless an organization or an individual can be assured of some regularity of appearance on the public channel, the opportunity to develop a viewing "constituency' . . . will be shight."). 
occasional crackpot. ${ }^{349}$ Limiting marketplace access to an area "that a benevolent government has provided as a safe haven for crackpots"350 is a far cry from the freedom of expression that Brandeis and Holmes extolled. In order to understand the continued popularity of unimpressive market reform measures such as the public access station proposal, a different perspective on the inarketplace of ideas must be explored.

\section{The FunCtion OF THE First AMENDMENT}

Whether the marketplace of ideas fulfills its classically articulated functions depends on whether it allows fair consideration of criticisin of the fundamental behefs and practices of society. ${ }^{351}$ Yet the market, as it functions within our society of high technology and unequal distribution of wealth, position, and communicative skill, is strongly biased toward status quo viewpoimts. A consideration of the social functions of the first ainendment and its inarketplace imagery helps to explain the continued use and popular acceptance of the market model.

\section{A. Fine-Tuning Among Elites.}

A inajor tenet of classic first amendinent theory is that each citizen has a right to participate in governmental decisionmaking. Under this tenet, the commands of government are legitimated by a democratic process that, when it functions properly, ensures that the subject has a hand in making the laws to which he submits. The difficulty with this view of "self-government" 352 is that the role of citizens in the actual Inaking of decisions involving pubhc issues is quite attenuated. Although Meiklejohn concludes that the marketplace of ideas guarantees that "public issues shall be decided by umiversal suffrage,"353 such issues actually are decided by those who claim to represent the people. ${ }^{354}$ Public opinion is not an amalgain of the independent thoughts of imdividuals choosing among alternatives im a totally open system. Instead,

349. D. Othmer, The Wired Island: The First Two Years of Public Access to Cable Television in Manhattan (Sept. 1973)("Watching public access programming is much like spending an evening in Times Square. It is exhilarating, frustrating, slocking and boring-above all, it is simply amazing.").

350. Tinker v. Des Moines Indep. Community School Dist., 393 U.S. 503, 513 (1969)("Freedom of expression would not truly exist if the right could be exercised only in an area that a benevolent governunent has provided as a safe laven for crackpots.").

351. See T. EMERSON, FirST AMENDMENT, supra note 1 , at 16.

352. Such a view of "self-government" is implicit in the writings of both Meiklejohn and Einerson. See sources cited supra note 1.

353. A. Meiklejohn, Political Freedom 27 (1960).

354. The "town ineeting" analogy so often relied upon to analyze the relationship of freedoin of speech to deinocracy is simply not an apt description of the process of cominunity decisionmaking. Individual citizens rarely if ever directly make or implement public decisions. 
an individual's opinion is influenced by his socialization and by the stature and style of the message bearer. Public opinion, therefore, is often the product of indoctrination and socialization. Right and wrong, and true and false virtually are predefined by a learned institutional inentality wherever these judgments affect the "vital interest" of our society.

The disagreennents we perceive within our society are indisputably real; a plethora of issues divide our communities with vociferous proponents on various sides. Most of these conflicts, lowever, are annong established groups battling for superiority while arguing over mere slradings of the same orthodox values. Their resolution involves societal fine-tuning rather than any basic reevaluation or critique of societal beliefs and practices. Although the positions of estabhished groups are not totally congruent, they have inore common than conflicting interests. Debate accordingly alinost always is conducted within understood and usually respected paranneters.

Froin this perspective, Board of Education v. Pico ${ }^{355}$ can be understood inore fully. Recall that Justice Brennan's plurality opinion, which held unconstitutional a school board's decision to remove certain books froin public school libraries, enphasized the distinction between removing books and siniply never acquiring thein. ${ }^{356}$ Yet, as asserted earlier, ${ }^{357}$ the distinction between expulsion and exclusion should be irrelevant under classic marketplace theory. Regardless of the method used, the perspectives contained in the affected books would be denied to the library user. ${ }^{358}$ If both the school board and local educators initially had agreed not to purcliase these books because of their objectionable content, it seens clear that the Court would not have found a first amendinent violation. ${ }^{359}$ Although the petitioners in Pico were

355. 457 U.S. 853 (1982). See generally supra notes $141-46$ and accompanying text.

356. Justice Brennan stressed that

the action before us does not involve the acquisition of books. Respondents have not sought to compel their school board to add to the school library shelves any books that students desire to read. Rather, the only action challenged in this case is the removal from the school libraries of books originally placed there by the sehool authorities, or without objection from them.

Pico, 457 U.S. at 862 (emphasis in original).

357. See supra text accompanying notes 143-44.

358. Because the books involved were likely available at other locations, such as commercial book stores, this assertion may be too strong. A more precise statement may be that access to the perspective contained in the excluded books intentionally was made more diffieult than access to "less objectionable" perspectives.

359. In an earlier case similar to Pico, the United States Court of Appeals for the Second Circuit concluded that

some authorized person or body has to make a determmation as to what the library collection will be. It is predictable that no matter what choice of books inay be made by whatever segment of academe, some other person or group may well disseut. The ensu- 
students, the propriety, content, and impact of student indoctrination was not the issue; the issue for the Court was only whether the school board would control this specific indoctrination process, or whether it would be left to the educators to decide which books the students might read. Essentially, this issue represents a dispute between two elite groups over control of the socialization process. These two groups probably would agree on the selection of the overwhelming majority of books. The rare case of disagreement demands only some fine-tuning. The marketplace functions to allow such fine-tuning among established groups whether they are school boards and educators, ${ }^{360}$ big government and big media, or Democrats and Republicans.

All these established groups imphicitly accept a "community agenda of alternatives" consistent with the dominant culture. This community agenda is the universe of alternative decisions accepted as possible by that dommant culture, including both preferred and unpreferred alternatives. ${ }^{361}$ Established groups may debate the question of which alternative is preferable, but the alternatives evaluated will all be drawn from a commonly held agenda. The community agenda of alternatives thus accounts for the empirically observable phenomenon that "[s]ome, perhaps most, possible alternatives are never considered in community decision-niaking." 362 The system encourages presentation of only a limited range of ideas from a limited group of individu-

\footnotetext{
ing shouts of book burning, witch hunting and violation of academic freedoin hardly elevate this intrainural strife to first amendment constitutional proportions. If it did, there would be a constant intrusion of the judiciary into the internal affairs of the school.

Presidents Council, District 25 v. Community School Bd. No. 25, 457 F.2d 289, 291-92 (2d Cir.), cert. denied, 409 U.S. 998 (1972).

360. In fact, the inarketplace may fine-tune even more subtly, encouraging debates only between school boards and the dominant teachers' union. See Perry Educ. Assn. v. Perry Local Educators' Assn., 103 S. Ct. 948, 951 (1983)(school board can agree with dominant teachers' union to provide only that union, and no other, access to interschool inail systein and teachers' mailboxes).

361. See N. PoLSBY, supra note 149, at 133-35; Deutsch, supra note 149, at 254.

362. N. PolSBY, supra note 149, at 133. A contemporary example of the community agenda is the movement for equal treatment of women. At one time people generally felt that woinen need not be accorded the equal protection of the law guaranteed by the fourteenth amendment because they were different from men, being weaker, less self-sufficient, and less mature. Cf., e.g., Bradwell v. lllinois, 83 U.S. 130, 141 (1873)("Man is, or should be, woman's protector and defender."). Statements to the contrary were rare and were usually discounted. It was not until this perception changed, particularly during World War I, see, e.g., C. CATT \& N. SHULER, WomaN Suffrage AND Politics 338 (1926); A. MARwick, The Deluge 95-105 (1965)(discussing British experience), that women's equality was accepted as a possible legal alternative; until then inarketplace consideration of legal equality among the sexes was not meaningful. Because an ideology initially perceived as radical becane acceptable and was absorbed into the community agenda of alternatives, its legal counterpart becane conceivable. For a discussion of the crncial question of how an alternative mitially beyond the community agenda coines to be accepted into it, see infra text accompanying notes $417-18$.
} 
als. Therefore, market access reform, without more, will have little impact on the diversity of views that the marketplace might adopt. ${ }^{363}$

Political plurahists strenuously attack the concept of a dominant culture and a correlative community agenda of alternatives. ${ }^{364}$ They reject the existence of any common consciousness in society. The work of Professor Robert Dahl is illustrative; his exploration of the political power distribution within New Haven in Who Governs? is particularly pertinent. ${ }^{365} \mathrm{Dahl}$ found that no single social or economic group either controlled, or regularly benefitted froin, the decisionmaking process. He concluded, therefore, that power in New Haven was held by constantly shifting issue-oriented coalitions. ${ }^{366}$

The pluralists' theory, as illustrated by Who Governs?, however, is built on the assumption that the community decisions being canvassed represent conflicts sufficiently serious to force all potentially affected groups to mobilize their resources to influence the outcome. The theory fails to recognize that established groups are unlikely to participate in the dynamic political behavior studied by Dahl unless they perceive that important interests potentially are threatened. Dahl failed in his study to distinguish between conflicts that an elite would perceive as threatening and those over which it could remain relatively indifferent because of its belief that its core interests were not endangered. ${ }^{367}$ Dahl, and the pluralists generally, also fail to consider whether different interest groups can clash in public debate over their positions even though these positions share and accept certain overarching common assumptions. This common acceptance of assumptions sets the parameters in which established groups conduct their public coinpetition, and it is only the battle taking place within these hinits that the pluralists observe. ${ }^{368}$

363. Market access reform is not likely to aid a group professing a perspective not encompassed by the community agenda. Such reform inay produce only a new "centrisin" with a slightly widened mainstream. See Lange, supra note 306, at 81-89.

364. Pluralisin developed predommantly as a hiberal attack upon the theory of a ruling elite, as expounded by radicals such as C. Wright Mills. See generally C. MiLls, THE PowER Elite (1956).

365. See R. Dahl, Who Governs? Democracy and Power in an AMERICAN City passim (1961). Dahl identified a number of important political decisions and the participants in them, studied the behavior of those participants in the course of decisionmaking, and analyzed the benefits and disadvantages various participants incurred as a result of the outcomes that ensued.

366. See id. at 85-86, 169-220.

367. For similar discussions of these objections to Dahl's findings, see Bachrach \& Baratz, Two Faces of Power, 56 AM. Pol. SCl. REv. 947, 950-52 (1962); Deutsch, supra note 149, at 250-56; Simon, Notes on the Observation and Measurement of Political Power, 15 J. PoL. 500 (1953).

368. This objection to the pluralist's inethods arises from the pluralist's failure to take into account what Professor Carl Friedrich first described as the "rule of anticipated reactions": the behef that much political behavior is govemed by the actor's perceptions of, and adjustments for, 
Plurahism recognizes the extent to which the group has replaced the individual as the potent force in modern society, ${ }^{369}$ but it views the group matrix as constantly open, fluid, and shifting. At one time this theory inay have been an accurate account of American society; once pluralists depict the group matrix, however, the picture tends to become frozen. Thereafter, when changes occur in the pattern of social or economic groupings, pluralist theorists tend not to acknowledge them because such new groupings deviate from the accepted picture. A pluralist view of society, therefore, tends to favor existing groups over those in the process of formation. As Robert Paul Wolff observed in his critique of plurahism:

There is a very sharp distinction in the public doinain between legitimate interests and those which are absolutely beyond the pale. If a group or interest is within the framework of acceptability, then it can be sure of winning some measure of what it seeks. . . . On the other hand, if an interest falls outside the circle of the acceptable it receives no attention whatsoever and its proponents are treated as crackpots, extremists or foreign agents. ${ }^{370}$

The marketplace is useful for resolving differences among perspectives "within the framework of acceptability" but it is blind to potential evils outside of this boundary that afflict the body politic on the whole. Consequently, the marketplace cannot be depended upon to consider thoroughgoing social revisions that challenge, and help our evaluation of, the fundamental beliefs and practices of society.

Despite the idealism of pluralists and others, free speech is not useful primarily for the discovery of truth or the creation of an informed citizenry. An individual's experience bestows knowledge as mucli as do the lessons learned from speech. Individual choice and societal change therefore depend less upon free expression than upon the development of new needs, demands, and experiences allowing, or

the reactions he expects would be provoked by possible actions on his part. See C. FrIEDRICH, Constitutional Government AND Politics 16-18 (1937); see also Deutsch, supra note 149, at 252-53; Simon, supra note 367 , at 505-06.

The pluralists ignore the possibility that policymaking institutions may ensure their own legitimacy by functioning like a chameleon and changing their color to conform to the dominant cultural environment. $C$. Ingber, supra note 75, at 346-48 (discussing the responsive nature of the Supreme Court). Instead of blindly assuming that plurahistic competition determines public policy, researchers must explore how dominant values, cultural myths, rituals, and political institutions tend to favor the vested interests of soine groups relative to others. See Bachrach \& Baratz, supra note 367 , at 950 .

369. Pluralism, therefore, views as pure rletoric the presumption of the Jacksonian model of deinocracy that each person's ideas have the same inherent worth and that the widest possible articulation of different views maximizes society's benefit. See L. LEwIs, supra note 45, at 199201. First amendment inarketplace theory also professes this assumption of Jacksonian democracy. See supra notes 50-53 and accompanying text.

370. Wolf, supra note 195 , at $43-44$. 
forcing, individuals to change their perspectives. ${ }^{371}$ To focus on diversity of expression rather than diversity of experience is to focus on the dependent rather than the independent variable. Yet the dominance of the market model and conventional theories of the first amendment demonstrate our nation's einphasis on free expression. This focus is, obviously, less threatening to establisled norms because of its status quo bias. In sliort, in the United States today free speeclu is a device by which established interests may both refine their minor differences and promote their commonly held assumptions of truth; it is not a device to change society.

\section{B. Bestowing an Advantage on National Elites.}

There are situations, however, when even narket fine-tuning is insufficient to resolve conflicts among established groups. Sucli occasions often arise durmg conflicts between the perspectives of national and local power elites. ${ }^{372}$ When the community agenda of alternatives for national and local communities do not coincide, the first amendment may play a determinative role because the forum for final resolution of such differences will be the federal courts. ${ }^{373}$ These courts more readily overturn the actions of state and local officials than those of the federal government. ${ }^{374}$ The first anrendment, therefore, gives national interests a veto of sorts over local established group positions by ensurmg finality to decisions made by institutions attuned to nationally lield perspectives. ${ }^{375}$ First amendment protection of the civil rights novement, ${ }^{376}$

371. Cf. Nagel, supra note 18, at 304-05 (listing factors that "coalesce to determine the amount of tolerance or intolerance" of society).

372. A "locality" can in some instances counprise an entire region of the country, as was the case in the civil rights dispute.

373. See 28 U.S.C. $\$ \S 1331-1332$ (1976)(federal question and diversity jurisdiction for federal district courts); 28 U.S.C. $\$ 1254$ (1976)(Supreme Court review of federal appellate court decisions); Martin v. Hunter's Lessee, 14 U.S. (1 Wheat.) 304 (1816)(Supreme Court authority to review constitutional validity of final decisions of highest state courts).

374. See supra note 291 .

375. This may be refiected in the Supreme Court's decision to overturn a state reply statute in Miami Herald Publishing Co. v. Tornillo, 418 U.S. 241, 258 (1974), while upholding the reply requirement of the FCC's fairness doctrine in Red Lion Broadcastimg Co. v. FCC, 395 U.S. 367, 375 (1969). See supra note 291 and accompanying text.

376. See Gregory v. Chicago, 394 U.S. 111, 111-13 (1969)(reversing disorderly conduct convictions of "peaceful" and "orderly" civil rights marchers who disobeyed police order to disperse); Brown v. Louisiana, 383 U.S. 131, 136-37, 142-43 (1966)(plurahty opimion)(reversing breach of the peace conviction for sit-down protest in public library); Cox v. Louisiana, 379 U.S. 536, 538, 552, 558 (1965)(reversing convictions of civil rights marchers for disturbing the peace and obstructing public passages, on numerous constitutional grounds); Edwards v. South Carolina, 372 U.S. 229, 230, 236-38 (1963)(reversing convictions of 187 persons arrested for breach of the peace during civil rights inarch). 
and, at times, of the arts, ${ }^{377}$ may be viewed not as the protection of dissident or outcast groups and perspectives, but as the imposition of national values over an overtly deviating local elite.

\section{System Legitimacy and the Myth of Autonomy.}

In spite of the fact that the marketplace of ideas significantly favors established groups and values, so long as representatives of disadvantaged groups and viewpomts do not perceive themselves as systematically excluded from the market, ${ }^{378}$ the resultant social systen remaims "legitimate." Before the significance of the first amendment can be understood fully, one must first appreciate its mythical function and also take notice of the practical steps that most courts and commentators have taken to preserve the perception of myth as reality.

Although, when imvoking "freedom of expression," people usually are focusing on the individual rights of those who wish to express theinselves, first amendment theory usually emphasizes the interest of audiences. ${ }^{379}$ The right to send ideas, to communicate, is most often viewed as a right to influence or to confront one's audience. ${ }^{380} \mathrm{~A}$ number of theorists have questioned whether such a public utility justification for the freedom of speech is sufficient. ${ }^{381}$ Some have proposed

377. When local artistic rejection conflicts with national artistic acclaim, the Supreme Court has found the local response a violation of first amendment principles, in spite of the Court's articulated deference to local community aesthetic perspectives in Miller v. California, 413 U.S. 15, 30-34 (1973). See Jenkens v. Georgia, 418 U.S. 153, 161 (1974)(finding film Carnal Knowledge to be protected speech in spite of local jury's determination that it was "patently offensive" under community standards); see also Southeastern Prounotions, Ltd. v. Conrad, 420 U.S. 546, 549 n.4, 560-61 (1975)(denying ununicipal board nranaging city theatre in Chattanooga the right to refuse permission for theatre's use for showing of inusical Hair under policy that called for its use only "for cultural advancement and for clean, healthful entertainment").

378. A popular consensus in favor of a narketplace biased toward the status quo does not necessarily indicate that established groups mampulate that consensus in soine conscious sense. Established groups would presuniably act to oppose any atteinpt to change the commnnity agenda of alternatives to their disadvantage; however, as long as no such atteinpt occurs, as long as the populace geuerally perceives the inarket outcoines as properly derived, there is no reason to suppose that the established group's acceptance of the system is any nore self-conscious than its acceptance by any other group.

379. Scanlon, Freedom of Expression and Categories of Expression, 40 U. PITT. L. REv. 519, 528-29 (1979).

380. Justice Brennan did attempt to characterize the essence of free speech as an interest of the communicator rather than of the recipient of communication when he noted that "the right to receive ideas follows ineluctably froun the sender's First Amendment right to send then .... . More importantly, the right to receive ideas is a necessary predicate to the recipient's ineaningful exercise of his own rights of speech, press, and political freedoin." Board of Educ. v. Pico, 457 U.S. 853, 867 (1982).

381. See, e.g., Baker, supra note 1, at 964-67, 974-81; Scanlon, supra note 40, at 1043-46. 
a theory of personality, a liberty perspective ${ }^{382}$ viewing the freeing of the human spirit as the prime social value of free speech. ${ }^{383}$ Still other theorists argue that the first amendment assures a necessary precondition of legitimate government by forcing the state to respect individuals as "equal, rational and autonomous moral beings." 384 Professor C. Edwin Baker asserts:

Both the concept of coercion and the rationale for protecting speech draw from the saine ethical requirement that the integrity and autonomy of the individual moral agent must be respected. Coercive acts typically disregard the ethical principle that, in interactions with others, one must respect the other's autonony and integrity as a person. When trying to influence another person, one must not disregard that person's will or the integrity of the other person's mental processes. ${ }^{385}$

In contrast to Professor Baker's position, the first ainendinent protects only the appearance of individual autonomy, while it permits government and private power elites to socialize and indoctrinate the citizenry in support of these groups' beliefs.

1. The Myth of Autonomy. Both branches of the liberty/autonomy theory of the first amendment are plagued with difficulties. As a hiberation of the human spirit, speech is no more pivotal than is any other human activity. ${ }^{386}$ In fact, if an individual's perspective depends on how his interests, needs, and experiences lead him to slice and categorize sensory data, then the ability to follow a wide range of behavioral options is inuch more crucial for the liberation of the human spirit than is frecdom of expression alone. Yet only freedom of expression is guaranteed. Emerson, in explaining this special status for

382. This liberty theory may be deduced from Justice Brandeis's concurring opinion in Whitney v. California, 274 U.S. 357, 375 (1927):

Those who won our independence believed that the final end of the State was to make men free to develop their faculties . . . . They valued liberty both as an end and as a means. They believed liberty to be the secret of happiness and courage to be the secret of hiberty.

But given the facts of the case, and the result of the decision that led to these beautiful abstractions, one remains skeptical of the theory's relevance.

383. Professor David Richards, for example, contends that "the first amendment rests more fundamentally on the moral liberties of expression, conscience and thought; these liberties are fundamental conditions of the integrity and competence of a person in mastering his life and expressing this mastery to others." Richards, Free Speech and Obscenity Law: Toward a Moral Theory of the First Amendment, 123 U. PA. L. Rev. 45, 82 (1974). This view parallels Professor Emerson's concern for individual self-fulfillment and development. T. EMERSON, FIrST AMENDMENT, supra note 1, at 4-7; cf. L. TRIBE, supra note 13, \& 12-1, at 576 (arguing that no instrumentalist explanation can do justice to first amendment).

384. Baker, supra note 1, at 991; see Scanlon, supra note 40, at 214.

385. Baker, supra note 1, at 1001-02.

386. See supra note 67. 
expression, admits that it is because "expression is normally conceived as doing less injury to other social goals than action. It generally has less immediate consequences, is less irremediable in its impact." 387 Although Enerson identified the inost important difference between speech and behavior, he missed its significance. Expression is allowed precisely because a person's speech is of hittle danger when his experiences have first been molded and controlled. Established values are not threatened, for the individual is given only the sense of autonoiny while the potential impact of this "autonorny" upon the governing system is minimized.

The branch of the liberty/autonomy theory that emphasizes the relationship between individual autonony and governmental legitinacy is no less flawed. Iromically, the very scholars that recognize the fallacy of the marketplace assumption that individuals are independent, rational beings inaking unbiased choices anong competing market alternatives continue to einbrace a theory of liberty/autonoiny which also presumes such an individual. ${ }^{388}$

The inechanisms of socialization and indoctrination that are necessary correlates of nodern, coinplex society are, however, sufficiently subtle to allow the continued appearance of individual self-direction. The image of a neutral, objective, and fair narketplace of ideas promotes greater cohesion in society because people more readily accept adverse decisions if they feel they have, or could have, participated in the decisionmaking process. The citizenry perceives these decisions as legitimate rather than as imposed by dominant societal forces. ${ }^{389}$ The inythology of the first ainendment thus diverts efforts for social change away froin atteinpts to overthrow forcibly the existing social power structure and toward atteinpts to create a popular consensus. If a government's citizenry and ministers view the system as guaranteeing free expression, they inay well be content to replace the strategem of force with that of logic. ${ }^{390}$ Logic, however, only ensures consistency within a

387. T. EMERSON, Freedom of EXPRession, supra note 1 , at 9.

388. See, e.g., Baker, supra note 1, at 965-66. Individual autonomy presumably assumes that individuals may direct themselves and choose among alternatives without having predispositions engramed into them through indoctrination by government or private establishment groups. See Wellington, supra note 1, at 1135.

389. Professor Walter Weyrauch, when discussing the general public acceptance of adjudication, similarly observed that "the masks of objectivity, neutrality, and fairness give the legal process an independent power so that it is not [perceived to be] merely the tool of dominant social forces." Weyrauch, Law as Mask-Legal Ritual and Relevance, 66 CALIF. L. REv. 699, 718 (1978); see also T. ARNOLD, supra note 93, at 34.

390. See Dennis v. United States, 341 U.S. 494, 501 (1951)(Chief Justice Vinson rejecting the "right to rebellion"). 
given system of values. ${ }^{391}$ Consequently, its use as a means to condemn as "illogical" positions advocating an alternative value system is an act of subtle obfuscation.

2. Preserving the Myth. Public acceptance of the myth of individual autonomy and the neutral marketplace of ideas imparts an aura of legitimacy and authority to our government. Obvious discrepancies exist, however, between this myth and how the system actually functions. 392 If the public were fully aware of these discrepancies, the legitimacy of the decisionmaking process would be threatened. ${ }^{393}$ Protecting the myth thus is crucial to continued social stability. Preservation of the inyth requires both that channels appear to be open to all who wish to communicate, and that there appears to be no systematized manipulation of the individual's perspective through processes of indoctrination or socialization. The first amendment furthers both perceptions.

The first amendment guarantees each individual his day in a public arena. ${ }^{394} \mathrm{Be}$ it in appearing on a cable public access station, primting and distributing leaflets, or delivering a street corner speech, the vocal critic is allowed to ventilate his feelings and beliefs. This constitutes the "feel good" function of the first amendment. The issue is not whether any one else cares, or even histens, but that a communication opportunity exists to mollify the speaker. ${ }^{395}$ Although many people perceive these forums as an annoyance or disturbance (as in the street forum) or as dommated by oddballs and crackpots (as in the public

391. See Weyrauch, supra note 128 , at 800.

392. An observer must distinguish between a myth system that expresses all the assumptions, rules and prohibitions of a society, and an operational code that tells "operators"-the elitewhen, by whom, and how things are and can be done. This discrepancy, however, is not necessarily an intentional construction of elites, but rather is an inevitable byproduct of social complexity. See generally W. REISMAN, FOLDED LIES 1, 15-36 (1979)(outlining concepts of myth systems and operational codes).

393. See id. at 21; cf. Wasserstrom, Lawyers as Professionals: Some Moral Issues, 5 HuM. RTs. 1, 18 (1975)(discussing need for both professionals and clients to view professional as an elite if profession is to function effectively).

394. When Thurmond Arnold wrote that "the function of law is not so much to guide society as to comfort it," T. ARNOLD, supra note 93, at 34, he was referring to the function of law as a means of providing opponents of established conduct with at least a symbohic recognition of their precepts. For Arnold, it was essential to the legitimacy of the legal system that it assure each individual of "his day in court."

395. Emerson recognizes (without appreciating its role) that a system focused only on inaking limited communication channels available is functioning as little more than a pacifier. "Nor can it be said," admits Emerson,

that our system affords equality in the ability to communicate different points of view or to pursue different goals of inquiry. ... [N] either equal access to the mass media nor equal right to the support of pubhic funds presently exists. What we have secured in this 
access stations), their availability probably decreases the pressure to grant non-mamstream opinions access to more influential forums. ${ }^{396}$ Dissidents may thereby assume that they are standing firm against the stream while in fact they are being pulled along by the current. ${ }^{397}$

As long as the system bias in favor of established groups and dommant value perspectives remains subtle, and individuals do not feel manipulated or forced to believe or act in a certam way, the systern retains its legitimacy in spite of its biases. ${ }^{398}$ If the government wishes to preserve the myth of a free market, it cannot overtly prefer some messages over others. Accordingly, it is not surprising that the Court has held it impermissible for government to restrict speech on the basis of the message conveyed. 399

The legal process has helped to preserve the mytli by refocusing value conflicts away from the intense ideological plane to the less impassioned levels of process. ${ }^{400}$ By a remarkable sleight of hand the ideological differences between contending positions are forgotten; the ideological basis or significance of the underlymg governmental decision loses its importance. This shift in focus screens the inherent biases of the system while it gives challengers to the status quo the impression that an avenue is open to obtain both resolution of their conflict ${ }^{401}$ and

area is rather the right of the individual to follow the truth wherever it may lead, though the road is often a lonely one.

Emerson, Colonial Intentions and Current Realities of the First Amendment, 125 U. PA. L. REv. 737, 747 (1977).

396. This may explain the popularity of public access stations and the proposals suggesting the repeal of the fairness doctrine in favor of such stations. See supra text accompanying notes 347 50.

397. In Gertz v. Robert Welch, Inc., 418 U.S. 323, 344 n.9 (1974), the Supreme Court, by grudgimgly acknowledging the role of self-help in defamation, recognized that cliannels of communication must appear open more to ventilate the emotion of the speaker than to give information or insight to any potential audience.

398. The public is very sensitive to the appearance of being manipulated. When the government required automobile manufacturers to make automobiles so that the ignition system would not operate unless the front seat belts were buckled, the public showed its disapproval both vocally and by the numbers of individuals who illegally rewired the ignition system to bypass the safety mechanism. The public has never demonstrated a comparable displeasure toward governmentally mandated passive restraints, even though consumers are given no choice in their purchase. The difference between active and passive restraints is the perceived experience of beimg controlled that exists in one and is lacking in the other.

399. See, e.g., First Nat'l Bank v. Bellotti, 435 U.S. 765, 791 n.31 (1978); Linmark Assoc., Inc. v. Township of Willingboro, 431 U.S. 85, 94 (1977); L. TRIBE, supra note 13, \& 12-5, at 591; Bogen, The Supreme Court's Interpretation of the Guarantee of Freedom of Speech, $35 \mathrm{MD}$. L. REv. 555, 557 (1976); cf. United States v. O'Brien, 381 U.S. 367, 377 (1968)(government regulatory interests must be unrelated to the suppression of freedom of expression).

400. For a full discussion of the common use of procedure, ceremony and rhetoric as means to minimize conflict, see Ingber, supra note 94.

401. For a literary example of the use of procedure to settle conflicts while concealing ideological disputes, see Shirley Jackson's short story, The Lottery, in S. JACkson, THE LOTTERY 291 
official support of their positions. ${ }^{402}$ The leafleteer who wins the right to distribute his literature inust feel vindicated whether or not anyone reads or takes notice of his beliefs. Thus conflict successfully is refocused to a nonideological level ${ }^{403}$ because the individual challenger feels victorious while the policy or ideology with which he initially took exception continues. ${ }^{404}$

Board of Education v. Pico ${ }^{405}$ illustrates this function of the first amendment. Justice Blackmun, in a separate concurrence, attempted to confront Chief Justice Burger's assertion that there was no greater " "official suppression" in a "decision to remove a book" than in one "not to acquire a book desired by someone" in the first place.406 With exemplary candor Justice Blackmun confessed,

I also have some doubt that there is a theoretical distinction between reinoval of a book and failure to acquire a book. But as Judge Newman [of the Second Circuit] observed [in his concurrence to the lower court decision], there is a profound practical and evidentiary distinction between the two actions: "removal, more than failure to acquire, is likely to suggest that an impermissible political motivation may be present. There are many reasons why a book is not acquired, the most obvious being limited resources, but there are few legitimate

(1949). The society Jackson describes in The Lottery has no predilection against individual sacrifice for collective goals. In fact, it prefers such an arrangement. The story describes a communal ceremony wherein lots are drawn to determine who will be stoned to death for some unspecified community need. Although the eventual winner of the lottery objects, the objection is couched in terms of procedure- that the lots were drawn too quickly - and is not dirceted at the substance of the activity. Id. at 299.

402. The struggle for official support of a position often causes the idea of right and wrong, the ethical-juridical conception, to be overshadowed by emphasis upon which groups "win" and which "lose," the purely agonistic conception. See J. Hulzinga, Homo LudENS: A STudy of the Play-Element in Culture 78 (1949). In Greenland, for example, an Eskimo who has a complaint against another challenges him to a drumming contest. Id. at 85. The agonistic nature of this form of conflict resolution is readily apparent. Eskimo society, being in a less "advanced" phase of cultural development, has not developed the subtleties by which more developed societies conceal the "battle" element of conflict resolution.

403. In Board of Educ. v. Pico, 457 U.S. 853 (1982), for example, Justice Brennan emphasized his concern that the process used to remove the library books departed from the procedures previously used to make library decisions in the school system: "This would be a very different case if the record demonstrated that petitioners had employed established, regular, and facially unbiased procedures for the review of controversial materials. But the actual record in the case before us suggests the exact opposite." Id. at 874 (plurality opinion). Although conformity with process may assure consistency of treatment and limit the impact of a momentary whim, the student who desires to read the book is equally frustrated regardless of the process used for its removal. When special procedures are used the deprivation is merely more dramatic and overt. Consequently, the community is more likely to perceive that the school board has manipulated the students.

404. See Weyrauch, supra note 389, at 717-19.

405. 457 U.S. 853 (1982).

406. Pico, 457 U.S. at 892 (Burger, C.J., dissenting). 
reasons why a book, once acquired, should be removed from a library not filled to capacity." 407

The issue, therefore, is not access or expression, or even actual governmental control and indoctrination; the issue is instead the appearance of governmental manipulation and indoctrination.408 Justice Brennan, consequently, could conclude that the ultimate question was the intent underlying the school book removal, and not the impact of its removal on the marketplace.409

Admittedly, school officials may renove books for both bad motives and good motives. But if the Constitution grants a right to receive information, the reason for the denial should not inatter. ${ }^{410}$ The Court's concern in Pico clearly was that of avoiding the appearance

407. Id. at 878 n.l (Blackmun, J., concurring)(quoting Pico v. Board of Educ., 638 F.2d 404, 436 (2d Cir. 1980), affd, 457 U.S. 853 (1982)); see also 457 U.S. at $871-72$ (plurality opinion of Brennan, J.)(limiting holding to book removal).

408. Justice Rehnquist responded in dissent that if the issue was pubhic visibility "a school board's public annonncement of its refusal to acquire certain books would have every bit as much impact on public attention as would an equally publicized decision to remove the books." Pieo, 457 U.S. at 916-17. Although he may have been right, Justice Rehnquist neglected a vital aspect of reality. Given the nced for routine decisions as to which books the school should initially purchase, there would be no need to pubhicize a decision not to purchase any given book. The decision to remove a book already purchased, however, is likely to be sufficiently exceptional to require, if brought to public notice, some public explanation. Further, even assuming an isolated school board member pubhicly discusses his decision not to acquire a given book, the Court is likely to hold, as it did in United States v. O'Brien, 391 U.S. 367, 384 (1968), that "[w]luat motivates [one official] . . . to make a speech about [an institutional decision] . . . is not necessarily what motivates . . . others to [so decide] . . . and the stakes are sufficiently high for us to eschew guesswork."

409. Pico, 457 U.S. at $870-71$ (footnote onitted):

[W] hether petitioners' removal of books from their school libraries denied respondents their First Amendınent rights depends upon the inotivation behind petitioners' action. If petitioners intended by their removal decision to deny respondents access to ideas with which petitioners disagreed, and if this intent was the decisive factor in petitioners' decision, then petitioners have exercised their discretion in violation of the Constitution.

410. See id. at 917 (Rehnquist, J., dissenting). The concern in Pico over a governmental decisionmaking process tainted by an impure motivation is reminiscent of equal protection decisions establishing a distinction between de facto and de jure discrimination. E.g., Arlington Heights v. Metropolitan Hous. Corp., 429 U.S. 252, 265 (1977)(intent to segregate is the essential eleinent of de jure segregation); Washington v. Davis, 426 U.S. 229, 240 (1976)(proof of discriminatory intent is needed to show equal protection violation); Milliken v. Bradley, 418 U.S. 717, 745 (1974)(crossdistrict busing inproper without showing that intentional discriminatory acts had interdistrict effect); Keyes v. School Dist. No. 1, 413 U.S. 189, 208-09 (1973)(shifting burden to sclrool authorities once imtentionally segragative policy found in meaningful or significant segment of school system, and emphasizing distinction between de facto and de jure segregation). The focus on purposiveness in these decisions seemingly inandates an apparent purity of the decisional process while making no assurances as to the outcome of that process and its impact on the citizenry. Furthermore, courts and commentators have ably shown the probleuns inherent in the use of "legislative" intent. See, e.g., Palmer v. Thompson, 403 U.S. 217, 224-25 (1971)(Black, J.); Ely, Legislative and Administrative Motivation in Constitutional Law, 79 Yale L.J. 1205 passim (1970). 
rather than the reality of marketplace and governmental control and indoctrination. ${ }^{411}$

\section{Defusing Disenchantment. The idea that first amendment} freedom of expression functions to reduce social strife is not new. Justice Brandeis articulated this concept in Whitney v. California:

Those who won our independence. . . knew that order cannot be secured inerely through fear of punishment for its infraction; that it is hazardous to discourage thought, hope and imagination; that fear breeds repression; that repression breeds hate; that hate neenaces stable government; that the path of safety lies in the opportunity to discuss freely supposed grievances and proposed reniedies; and that the fitting remedy for evil counsels is good ones. ${ }^{412}$

Normally, commentators present defusing disenchantment as a secondary function of the first amendment, subordinate to such features as the search for truth, self-government, and individual development and autonomy. In the 1960's, "New Left" spokesmen viewed this function as the main purpose of the first amendment. They concluded that the

411. The extent to which established groups can use first amendment rhetoric to preserve the myth of individual autonomy may be mcreasing. In the modern welfare state, how the government decides to allocate its wealth can greatly imfluence people's substantive behavior. See generally Reich, The New Property, 73 YALE L.J. 733 (1964). As we become increasingly socialized, depending more and more upon government for the support of education, research, and the arts, the opportunity for governmental control of an individual's life will markedly increase, while the appearance of mdividual choice and autonomy is still preserved. The state appears to forbid nothing and merely seems to regulate distribution of governmental largesse "for the pubhic good." Under such auspices, and potentially consistent with first amendment doctrine, further inroads may be made on individual autonomy while retaining the appearances necessary to keep the system-legitimizing myth intact.

The concern expressed here is not equivalent to that of "unconstitutional conditions" frequently confronted by both jurists and scholars. See Frost \& Frost Trucking Co. v. Railroad Comm'n, 271 U.S. 583, 593-94 (1926); Hale, Unconstitutional Conditions and Constitutional Rights, 35 Colum. L. REv. 321 passim (1935); O'Neil, Unconstitutional Conditions: Welfare Benefits wilh Strings Attached, 54 CALIF. L. REv. 443 passim (1966). The doctrine of "unconstitutional conditions" seems to provide that a waiver of first amendinent rights cannot be annexed to the rationing of goods and services in the public sector. As Professor William Van Alstyne properly notes, however,

the doctrine merely protects preexisting rights from surrender-by-contract with the welfare state. It is limited to a case in which in exchange for sone valuable privilege, the state presumes to take from the individual some measure of freedom previously held by that imdividual and still held by all others.

Van Alstyne, The Möbius Strip of the First Amendment: Perspectives on Red Lion, 29 S.C.L. REv. 539,567 (1978)(footnote omitted). Thus, a poor individual receiving food stamps along with other poor individuals could not be demied further governmental aid for speaking critically of the President. A preexisting statutory right would be conditioned upon surrender of a constitutional one. Nothing in the doctrine, however, forbids government, during a bicentennial anniversary, for example, from allocating money to support the writing of patriotic and laudatory novels, plays, and poetry while creating no equal fund for works critical of the nation or supportive of foreign governments. Yet, such governmental promotion will clearly bias the marketplace and mold and direct the individual.

412. 274 U.S. 357,375 (1927)(Brandeis, J., concurring). 
system was "a meaningless sop, designed to siphon off protest and delude the populace into believing it has a participating voice."413

As the preceding pages liave demonstrated, these contentions are not without factual foundation. The first amendment may function more to placate and divert social tensions than to foster a bubbling of controversy and encourage individual diversity. But the New Left presumed that this effect resulted from a conspiracy of established groups. Their view of the system as a construct of devious, manipulating elites seems overly simplistic. The elites need not consciously create and impose a system in order to benefit from it. The bias or skew toward established groups and dominant value perspectives instead may be unavoidable $\mathrm{m}$ a high-technology society in which resources and skills are distributed unequally. 414 Dominant social perspectives may be molded not by conspiracies, but by social and economic externalities ${ }^{415}$ that make up the ecological setting. ${ }^{416}$ Those groups that perform in harmony with this ecological setting may be only the passive beneficiaries of the system in which they find themselves. ${ }^{417}$ It nay nonetheless be beneficial to society for the elite to feel responsible for the discrepancy between the mytl of the marketplace of ideas and the reality of socialization and indoctrmation. ${ }^{418}$ This unease may cause the elites to question the justification for, and their own qualifications to participate in, an elitist decisionmaking process that affects others. They also may question the wisdom, justice, authority, and necessity of their decisions.

\section{CONCLUSION}

In our complex society, affected by both sophisticated cominunication technology and unequal allocations of resources and skills, the marketplace's inevitable bias supports entrenclied power structures or

413. T. EMERSON, FReEdOM OF EXPRESSION, supra note 1, at 726. See generally R. WolfF, B. MOORE \& H. MARCUSE, supra note 191.

414. Cf. Nagel, supra note 18 (claiming the judicial process is unsuited to fulfill goals of the marketplace model).

415. These externalities might include the density of population and the division of labor. See generally E. DuRKheIM, SuICIDE 314-20 (J. Spaulding \& G. Simpson trans. 1951)(discussing externalities and their relationship to the individual and society); E. DuRkHeIM, Division OF LABOR IN SOCIETY 256-82 (G. Simpson trans. 1933)(discussing population and division of labor).

416. Ecological setting, like nationalism, includes the concepts of history and cultural development. Unlike nationalism, lowever, it does not necessarily include an individual perception of national identity; instead, it takes into consideration those factors whicl canse people to feel sucl an identification with a nation.

417. See Deutsch, supra note 149 , at 255.

418. A fuller discussion of the importance of elites being sufficiently imbued in the wyth to feel uncomfortable over the operating reality inay be found in Ingber, supra note 75, at 352-56. 
ideologies. Most reform proposals do little to help the marketplace reach its theoretical potential. Instead, such suggestions perpetuate the marketplace's status quo bias or result in unacceptable levels of governmental interference and regulation. These reform systems easily could decay into formal systems of governmental censorship or popular mdoctrimation.

This critique of the marketplace of ideas has led to the unsurprising conclusion that protection of expression alone does not guarantee an environment where new ideas, perceptions, and values can develop. A diversity of perspectives first requires a corresponding diversity of social experiences and opportunities. Consequently, in spite of the rhetoric surrounding it, freedom of speech by itself cannot ensure a diverse and interactive marketplace of ideas.

If we imtend to design a social and political system open to the development of diverse perspectives and values, we must first understand how an idea initially outside the community agenda of alternatives becomes accepted within it. There is little doubt that a change in the ecological setting necessarily creates new interests and needs which in turn alter perspectives. At rare times, as during the Depression, change comes swiftly. The severity and widespread dislocation caused by the Depression led to the abrupt realization that poverty was not necessarily the fault of the poor. Popular consensus so completely turned away from the traditional values of laissez-faire economics that policy decisions based on such values becanie disreputable. Such an abrupt change, however, is rare. Usually, ecological change takes considerable time. ${ }^{419}$ Perspectives change slowly enough so that the "new" ideas generally are absorbed into the community agenda as aspects of the status quo.

In addition to ecological change, new perspectives and values may be nurtured in a society that encourages, or at least permits, the development of new interests and experiences. Consequently, the status quo bias of the marketplace can probably be neutralized only by protecting a greater liberty of action-allowing people to choose among lifestyles offering differing roles and relationships-rather than merely supporting the freedom of speech. American jurisprudence simply lias focused on the wrong leg of Mill's theory of liberty. Instead of merely embracing his theory of the liberty of thought and discussion, ${ }^{420}$ our courts

419. For example, increased population and decreased demand for manual labor may slowly lead to greater acceptance of abortion, homosexuality, and women's liberation. Cf. Nagel, supra note 18, at 337 (arguing that the current mood of societal tolerance was partly caused by fundainental cultural shifts).

420. See supra text accompanying note 22 . 
should emphasize his view of limited societal authority over the individual, a theory of freedom of conduct:

[T] he sole end for which mankind are warranted, individually or collectively, in interfering with the liberty of action of any of their number, is self-protection. That the only purpose for which power can be rightfully exercised over any member of a civilized community, against his will, is to prevent harm to others. His own good, either physical or moral, is not a sufficient warrant. He cannot rightfully be compelled to do or forebear . . . because, in the opinions of others, to do so would be wise, or even right.421

Mill recognized, however, that rulers and fellow citizens tend "to impose their own opinions and inclinations as a rule of conduct on others." $422 \mathrm{He}$ thought that this imposition was hardly ever restrained by anything but the negation of power. ${ }^{423}$ Courts reasonably could interpret the first amendment's right of assembly and free exercise clauses to effectuate Mill's negation of power. Courts could construe these clauses to prevent governmental interference with the development of diverse communal groupings that perform their own distinct forms of socialization and indoctrimation. ${ }^{424}$ Such new groupings, in turn, inight insulate or reduce established groups' control of the marketplace. The legal doctrine that has developed surrounding these clauses, however, has kept thein from fulfilling this potential.

Courts generally have viewed asseinblies simply as a ineans of conveying speech and spreading ideas. Consequently, the Supreme Court has given rights of assembly only subsidiary importance, subjecting thein to regulation as "speech-plus." 425 Furthermore, the Court has never considered the "freedoin of association," 426 arguably based within the right of assembly, to be a unique, independent right. Instead, the Court has treated freedom of association as little more than a shorthand phrase that protects traditional first amendment rights of speech

421. J. Mill, supra note 5, at 8-9.

422. Id. at 12 .

423. Id.

424. Such was the view of one scholar. See Baker, supra note 1, at 1029-39.

425. See T. EMERSON, FreEdom OF EXPRESSION, supra note 1, at 292-98; Baker, supra note 1, at 1030.

426. The notion of a right of association developed in the 1950's and 1960 's as the federal and some state governments sought to identify ineinbers of allegedly dangerous organizations such as the Communist Party and the NAACP. See E. CoRwin, THE Constitution of THE UNITED States of AMERICA: ANALYSis AND INTERPRETATION 966 (rev. ed. 1973). Decisions considering the right are numerous. See, e.g., Buckley v. Valeo, 424 U.S. 1 (1976); United Mine Workers v. Illinois State Bar Ass'n, 389 U.S. 217 (1967); Brotherhood of R.R. Trainmen v. Virginia ex rel. Va. State Bar, 377 U.S. 1 (1964); NAACP v. Button, 371 U.S. 415 (1963); Shelton v. Tucker, 364 U.S. 479 (1960); Bates v. City of Little Rock, 361 U.S. 516 (1960); NAACP v. Alabama ex rel. Patterson, 357 U.S. 449 (1958); see also Griswold v. Connecticut, 381 U.S. 479, $482-84$ (1965). 
and petition as exercised by individuals in groups. ${ }^{427}$ To the Court, the freedom of association has meaning only when the association's participants are attempting to accomphish an objective independently protected by the freedom of speech. ${ }^{428}$ Accordingly, people may associate to advocate certain behavior but may not associate to take action to implement the ideas advocated. Psychology has long recognized, however, that requiring behavior inconsistent with belief creates tension within an individual. That tension is often resolved by altering the belief systein to make it consistent with the compelled conduct. This theory of cognitive dissonance ${ }^{429}$ recognizes an inalienable connection between action and belief. The Court's attempt to separate them accords with the mytl of individual autonomy discussed earlier. ${ }^{430}$ To be meaningful, assembly and associational rights unust transcend expression and protect the right of individuals to combine to pursue and fulfill communal goals. ${ }^{431}$

The Constitution, lowever, has developed as an unrealistically atomistic document. ${ }^{432}$ For example, restrictive interpretation has hindered the potential of the free exercise clause to foster diverse ways of living. As early as 1879 , the Supreine Court interpreted the free exercise clause to permit a state to prohibit any action regardless of its reli-

427. See, e.g., Bates v. City of Little Rock, 361 U.S. 516, 522-23 (1960)("And it is now beyond dispute that freedom of association for the purpose of advancing ideas and airing grievances is protected by the Due Process Clause of the Fourteenth Amendment."); NAACP v. Alabama $e x$ rel. Patterson, 357 U.S. 449, 460-61 (1958)("Effective advocacy of both public and private points of view, particularly controversial ones, is undeniably enhanced by group association, as this Court has inore than once recognized by remarking upon the close nexus between the freedoms of speech and assembly.").

428. See L. TRIBE, supra note $13, \S 12-23$, at 701-02. For an example of a judicial effort to limit the freedom of association to group action furthering only free speech objectives, see Runyon v. McCrary, 427 U.S. 160, 175-76, (1976)(parents could establish private educational academies to advocate segregation, but could not employ admission practices impleunenting their ideas without violating Civil Rights Act, 42 U.S.C \& 1981 (1976)).

429. The literature on cognitive dissouance is extensive. See, e.g., J. BreHM \& A. CoHEN, Explorations in Cognitive Dissonance (1962); L. Festinger, Conflict, Decision, and Dissonance (1964); R. Wickiund \& J. Brehm, Perspectives on Cognitive Dissonance (1976); Faxia, Zanna \& Cooper, Dissonance and Self-Perception: An Integrative View of Each Theory's Proper Domain of Application, J. Experumental Soc. PsYcholooy, Sept. 1977, at 46479; Nichols \& Duke, Cognitive Dissonance and Locus of Control: Interface of Two Paradigmis, J. Soc. PsYcHology, Apr. 1977, at 291-97; Tesser \& Cowan, Some Attiudinal and Cognitive Consequences of Thought, J. Research Personality, June 1977, at 216-26; Yashida, Effects of Cognitive Dissonance on Task Evaluation and Task Performance, JAPANESE J. PsYCHOLOGY, Oct. 1977, at 216-23.

430. See supra text accompanying notes $386-91$.

431. As argued earlier, see supra text accompanying notes $364-70$, freedom of speecl and the narketplace of ideas alone do not assure a pluralistic society.

432. See L. TRIBE, supra note $13, \S 12-23$, at 700-01. 
gious implications, so long as it did not formally prohibit a belief. ${ }^{433}$ Chief Justice Waite insisted that "Congress was deprived of all legislative power over mere opimion, but was left free to reacls actions which were in violation of social duties or subversive of good order." 434 Under the Court's interpretation, the freedom to believe was absolute but the freedom to act upon what one believed was subject to governinental regulation. 435

Yet if one cannot behave in compliance with one's religious or ethical behefs, these behefs are of little importance. ${ }^{436}$ As argued earlier, fundamental religious beliefs are extremely difficult to hold if one is required by the state to act inconsistently with them. ${ }^{437} \mathrm{~A}$ change of belief may be much easier on the psyche than the burden of eternal damnation. Although our society may require some limits on freedom of religion, both courts and commentators must question more seriously the extent to which religious behavior should be insulated from governmental authority. ${ }^{438}$

433. Reynolds v. United States, 98 U.S. 145, 168 (1879)(upholding the application of federal law prohibiting polygomy to Mormon whose religion required him to engage in the practice).

434. Id. at 164 .

435. See Cantwell v. Connecticut, 310 U.S. 296, 303-04 (1940).

436. Baker, supra note 1, at 1037; see, e.g., Murdock v. Pennsylvania, 319 U.S. 105 (1943)(distributing rehigious pamphlets is protected right not subject to license tax).

437. See supra text accompanying notes 429-30 (discussion of cognitive dissonance).

438. Wisconsin v. Yoder, 406 U.S. 205 (1972), was a small step in the direction of constitutional protection for differing lifestyles. The Supreme Court held that Wisconsin could not require members of the Amish church to send their children to public sclool after the eighth grade. Yoder, 406 U.S. at 234. Two aspects of the Yoder decision, however, give us reason to pause before attributing to the Court an interest in protecting divergent lifestyles. First, the Court stressed that similar claims would likely be unsuccessful, if founded upon a personal or philosophical rejection of secular values, $i d$. at $215-16$, or a "recently discovered . . . 'progressive' or more cnlightened process for rearing children for modern life," id. at 235. See J. Nowak, supra note 158, at 877-78; L. TRIBE, supra note 13, \& 14-10, at 856-57; Baker, supra note 1, at 1036.

This narrow approach to religion, distinguishing religion from fundannentally held beliefs, is inconsistent with the broad perspective the Court used in the conscientious objector decisions. See United States v. Seeger, 380 U.S. 163, 166 (1965)(sincere belief occupying "a place in the life of its possessor parallel to that filled by the orthodox belief in God" qualifies petitioner for conscientious objector status); see also Welsh v. Umited States, 398 U.S. 333, 340, 343 (1970)(petitioner who held deep conscientious scruples against participation in war was entitled to conscientious objector status despite his lack of belief in a "Supreme Being"). See generally Note, Defining Religion: Of God, the Constitution and the D.A.R., 32 U. CHI. L. REv. 533 (1965). In cases imvolving tax exemptious for religious institutions, other courts have construed the applicable statutes to include non-theistic groups, interpreting "religion broadly in terms of the social function of the group rather than the context of its beliefs." Galanter, Religious Freedom in the United States: $A$ Turning Point?, 1966 Wis. L. REv. 217, 260; see Fellowship of Huinanity v. County of Alameda, 153 Cal. App. 2d 673, 692-93, 315 P.2d 395, 406 (1957)(equal protection rationale). Even though the conscientious objector and tax exemption cases add questions of statutory interpretation, the explicit attempt to separate Yoder fron the approach of these decisions suggests a continued insensitivity or resistance by the Court to the important role sucl divergent groupings could play. 
Despite past doctrinal developments, the Court conceivably could develop a constitutional safe-harbor for divergent groups by developing a fresh approach to the right of association and free exercise. Judicial and scholarly effort should be pressed into service to develop an area of freedom of conduct rather than reiterating the importance of a nearly impotent freedom of expression. Such a freedom of conduct imight allow the diversity of perspective necessary for the marketplace of ideas in fact to approach its myth.

Although the Court should focus on developing a freedom of conduct, it should exercise caution in so doing. The saine factors that have created an impotent marketplace of ideas inay influence an individual's exercise of a right to choose a lifestyle under a freedom of action. If society's indoctrination and socialization process molds an individual's perspectives and values, what then would motivate one to join or create a group offering real, rather than merely costume differences in roles and relationships? ${ }^{439}$ Perhaps the myth of individual autonomy is the most for which we can strive given our highly coinplex society with sophisticated communication technology and unequal distribution of resources.

Nevertheless, we must pierce the inyth of the neutral marketplace of ideas and expose the flawed market inodel assuniptions of objective truth and the power of rationahity. A system of freedom focused exclusively on expression fosters only incremental change within a community agenda of alternatives reflective of the doininant culture. 440 Other than assuring dominance of national perspectives, the marketplace encourages only fine-tuning aniong established groups. To a much greater extent than it nourishes criticisn and change, a system of freedom of expression adds an aura of legitimacy to the governing system by protecting the appearance of individual autonomy. Individual disenchantnient is defused by preserving the facade both of open and effective channels of communication and of a system that ensures individual self-determination.

The second point which counsels that the Court did not mean to extend Yoder beyond its facts is the Court's emphasis that the Amish lifestyle posed no threat to the mamtenance of order and social control. 406 U.S. at 222. Perhaps the Court merely was swayed by a belief that the Amish posed no challenge to traditional values and norms. See Baker, supra note 1, at 1037.

439. Further, if the titillation of rebellion-tweaking the nose of the establishment-encourages imdividuals to create or join dissident groups, tolerance of diversity might reduce that titillation and lead to greater conformity. This, however, is a convenient argument which established groups can use to justify their dominance, and it should be discounted accordingly.

440. Although those who prefer the dominant culture may find desirable a system that only allows imcremental change, such a system is inconsistent with the often-proclaimed goals of seeking truth, democratic government, and imdividual freedom and dignity. 
Although I hope to have shed some light on the functioning of the first amendment and the marketplace of ideas, the costs of such analysis must be acknowledged. Periods of enlightenment can weaken the mysticism that bestows legitimacy upon institutions, such as the law, which are, at least partially, based on faith. ${ }^{441}$ But skepticism is, at times, a healthy perspective. A jurist no more radical than Judge Learned Hand once mused:

I often wonder whether we do not rest our hopes too much upon constitutions, upon laws and upon courts. These are false hopes; believe me, these are false hopes. Liberty lies in the hearts of men and women; when it dies there, no constitution, no law, no court can save it; no constitution, no law, no court can even do much to help it. While it lies there it needs no constitution, no law, no court to save it. 442

Possibly, as Hand suggests, we have expected too much of the first amendment's freedom of speech; we may have done too little to free the hearts of men and women so that we can live in an open society, and not merely talk of it.

441. A friend and teacher once posed the question whether "the saying of the Mass in the vernacular [forbode] the beginning, or the end, of the relevance of that sacrament to the lives of the believers?" Deutsch, supra note 149, at 261. The question remains relevant for inuch of recent legal scholarship. Cf. Nagel, supra note 18, at 305 (describing the judiciary's ambitious role in free speech as being based "in large measure" on faith).

442. The Spirit of Liberty, Papers and AdDresses of Learned Hand 189-90 (1. Dilliard ed. 1960). 